Portland State University

PDXScholar

11-1-1995

\title{
Medieval Christocentric Imagery in Selected Novels by Georges Bernanos
}

\author{
Catherine Ann Elia \\ Portland State University
}

Follow this and additional works at: https://pdxscholar.library.pdx.edu/open_access_etds

Part of the French and Francophone Language and Literature Commons Let us know how access to this document benefits you.

\section{Recommended Citation}

Elia, Catherine Ann, "Medieval Christocentric Imagery in Selected Novels by Georges Bernanos" (1995). Dissertations and Theses. Paper 5024.

https://doi.org/10.15760/etd.6900

This Thesis is brought to you for free and open access. It has been accepted for inclusion in Dissertations and Theses by an authorized administrator of PDXScholar. Please contact us if we can make this document more accessible: pdxscholar@pdx.edu. 
The abstract and thesis of Catherine Ann Elia for the Master of Arts in French were presented November 1, 1995, and accepted by the thesis committee and the department.

COMMITTEE APPROVALS :
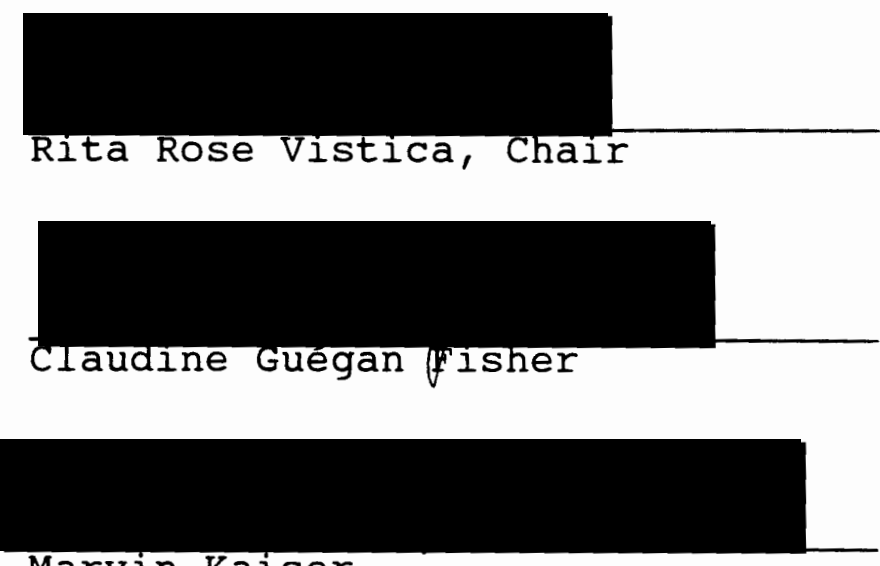

Marvin Kaiser

Representative of the office of Graduate Studies

DEPARTMENT APPROVAL:

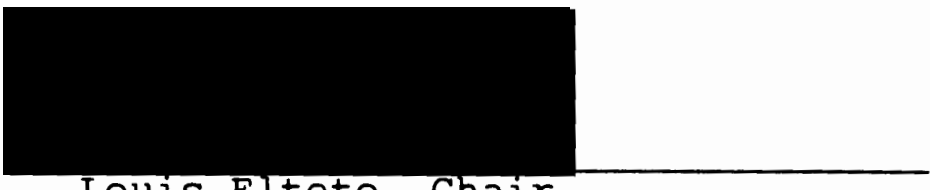

Louls Elteto, Chair

Department of Foreign Languages and Literatures

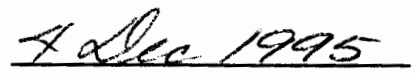




\begin{abstract}
An abstract of the thesis of Catherine Ann Elia for the Master of Arts in French presented November 1, 1995.

Title: Medieval Christocentric Imagery in Selected Novels by Georges Bernanos
\end{abstract}

In the fictional world of the twentieth century author, Georges Bernanos, a medieval spirituality is reflected through Christocentric imagery.

This study highlights the Christocentric focus of medieval spirituality found in three bernanosian characters: Donissan in Sous le Soleil de Satan, Chantal in La Joie, and le curé d'Ambricourt in Journal d'un curê de campagne. Two medieval images, the Mirror and the Way, provided a backdrop for considering common thematic characteristics.

This study is divided into two parts. Part one comprises two chapters which present background for textual analysis in Bernanos' three novels. Chapter one explores formative elements in medieval spirituality. These include: descriptions of the medieval mindset, clerical and ecclesial influences, devotional trends related to themes of Christocentric imitation, edification images, specifically, the Mirror and the Way, and chivalry. 
Chapter two presents formative elements in Bernanos' spirituality. Familial, clerical and ecclesial influences of his childhood contributed to his christocentric spirituality. Biographical descriptions of Bernanos' adolescent and adult years reveal similarities of his lived experience to medieval themes of pilgrimage, chivalry and imitation.

In Part Two, Donissan, Chantal and le curé are considered in the context of medieval trends to imitate Christ. Images of the way and the Mirror emerge in the four chapters of this section.

In chapter three, a textual analysis is presented which juxtaposes virtuous qualities of each main character to the virtues of the medieval devotion to the Infancy.

In chapters four and Iive, the characters are described in relation to another major devotional trend of medieval times: the Passion. Chapter four considers the bernanosian saints as imitators of Jesus' agony while chapter five addresses their imitation of his way of the cross. In both chapters, imagery related to medieval Christ-like imitation is identified.

Chapter six highlights themes of death and resurrection, the culminating steps of the medieval journey of imitation. Descriptions of Bernanos' saintly instruments of grace emphasize their adherence to the 
medieval pursuit towards wholeness. Dawn imagery and the theme of communion of saints are treated in this discussion of transformation.

Endnotes accompany each of the six chapters. 


\title{
MEDIEVAL CHRISTOCENTRIC IMAGERY \\ IN SELECTED NOVELS \\ BY GEORGES BERNANOS
}

by

CATHERINE ANN ELIA

A thesis submitted in partial fulfillment of the requirements for the degree of

\author{
MASTER OF ARTS \\ in \\ FRENCH
}

Portland State University

1995 
TABLE OF CONTENTS

ACKNOWLEDGEMENTS . . . . . . . . . . . . . . . . iv

PART ONE: MIRROR AND WAY

BERNANOSIAN AND MEDIEVAL SPIRITUALITY • . 1

CHAPTER I . . . . . . . . . . . . . . . . . . . 1

INTRODUCTION : MEDIEVAL INFLUENCES AND
CHRISTOCENTRIC IMAGERY . . . . . . . . 1

FORMATIVE ELEMENTS OF A MEDIEVAL
SPIRITUALITY . . . . . . . . . . . . . 4

A Fundamental Concept of spirituality 4

The Medieval Mindset . . . . . . . . 6

Medieval Clerics and the Church . . . 9

Medieval Christology and Imitation: 13

Images of Edification: the Mirror and the way..... . . . . . . . 23

Chivalry and the Quest . . . . . . 27

Chapter II . . . . . . . . . . . . . . 39

FORMATIVE ELEMENTS OF BERNANOS'.
SPIRITUALITY . . . . . . . . . . . 39

Bernanos' Childhood and the Medieval

Mindset. . . . . . . . . 39

Clerical and Ecclesial Influences . . 45

Bernanos: Witness and Knight... . 50

The Pilgrim's Quest . . . . . . . . 57

PART TWO: IMITATION AND PILGRIMAGE

THE BERNANOSIAN WAY AND MIRROR OF SELF-KNOWLEDGE 65

Chapter III . . . . . . . . . . . . . . 65

CHILDHOOD: THE BEgINNING OF THE WAY . . . 65

CHILDLIKE POVERTY, HUMILITY AND SIMPLICITY 69

Donissan: a poor and simple child . . 69

Chantal: a mystical child ... . . 74

The curé: an ordinary child . . . . . 78

MATERnAL TENDERNESS ........... . . 87

The tenderness of Menou-Segrais . . 88 
The tenderness of Chevance . . . . . 89 The tenderness of the curé de Torcy . 91 Mirrors of tenderness . . . . . . 93

THE CHIVALROUS CHILD . . . . . . . . 97

Quest, virtue and battle..... . 97

CHAPTER IV . . . . . . . . . . . . 112

THE AGONY . . . . . . . . . . . . . 112

The agony of Donissan . . . . . . 115

The agony of Chantal. . . . . . . 127

The agony of the curé . . . . . . . . 138

ChAPTER V . . . . . . . . . . . . . . 158

THE WAY OF THE CROSS . . . . . . . . . 158

Donissan's Way of the cross . . . . 158

Chantal's Way of the Cross... . . 169

The curé's way of the cross . . . . 176

CHAPTER VI................ . 183

DEATH AND RESURRECTION . . . . . . . 183

DEATH . . . . . . . . . . . . 186

Donissan ............ . 187

Chantal .............. . 191

The curé . . . . . . . . . . . . 194

RESURRECTION ............. . 199

Signs of resurrection ....... . 200

Dawn .. . . . . . . . . . . 203

Communion of Saints . . . . . . 211

CONCLUSION . . . . . . . . . . . . . 220

APPENDIX A................... . . . 224

ABBREVIATIONS USED FOR BERNANOS'S WORKS
IN THIS THESIS . . . . . . . 224

WORKS CONSULTED . . . . . . . . 225 
BIBLIOGRAPHY OF BERNANOS AND

BERNANOSIAN STUDIES . . . . . . . 225

BIBLIOGRAPHY OF MEDIEVAL SPIRITUALITY

THEOLOGY AND IMAGERY . . . . . . 229 


\section{ACKNOWLEDGEMENTS}

Several persons have played a significant role in this project which began thirty years ago.

In loving memory, I gratefully acknowledge Joan Schillow, O.S.F., a foremost educator and woman of vision, whose enthusiastic efforts supported my early interest in Georges Bernanos' life and works.

To Professor Rita Rose Vistica, my dear friend and model teacher, I am immeasurably grateful. Her involvement in this project at its inception and her recent participation in its completion were invaluable. Professor Vistica's genuine interest in Bernanos, her suggestions and questions regarding organization and style, and her continual encouragement were especially appreciated.

To Professor Claudine Fisher, another inspirational teacher, I express heartfelt thanks for her enthusiasm, ongoing availability and time commitment as a reader.

I am also sincerely appreciative to Dean Marvin Kaiser for his insightful contributions and generous willingness to be the office of Graduate studies Representative on my thesis committee.

Finally, I thank my loving husband, for his continual support, patience, helpful input, time and shared computer skills. 


\title{
PART ONE: MIRROR AND WAY \\ BERNANOSIAN AND MEDIEVAL SPIRITUALITY
}

\begin{abstract}
CHAPTER I
INTRODUCTION: MEDIEVAL INFLUENCES AND CHRISTOCENTRIC IMAGERY
\end{abstract}

Contemporary commentaries and studies of particular themes in Georges Bernanos' fictional world provide proof of this early twentieth century author's authentic presence in his literary creation. In présences Contemporaines, Pierre and Dorothy Brodin cite a statement by Marcel Arland from La Nouvelle Revue Française which succinctly summarizes how Bernanos lives in his works. "Il [Bernanos] parle ses livres.. . Il y vit en partisan, il y combat, il y juge. . ." (Brodin et al. 153).

A great contribution which Bernanos has bequeathed to readers of his own and subsequent eras through his literary gift, is a voiced personal conviction that a spiritual world exists. It is a world which is constant and unchanging in the midst of chaotic contemporary societies. His novels are reminders of this world, and are therefore, more than mere stories.

The richness of Bernanos' characters and the imagery which surrounds them has been explored in many ways. Approaches vary according to the particular perspective in 
which bernanosian texts have been viewed. These interpretations include a range of contexts: from the political to the poetic; from the secular to the sacred; from the sociological to the psychological; from the literary to the linguistic; to name a few.

The context for comparison and understanding bernanosian texts in this study is medieval Christocentric imagery. I have chosen this perspective for two reasons. First, I have become familiar with the origin and development of medieval images through previous study. Secondly, occasional allusions in bernanosian studies relate the author's personal character, literary style and creative works to characteristics of the Middle Ages. These references prompted me to explore the Christocentric spirituality in his novels within the context of medieval imagery. 1

To begin with, Bernanos' novels resemble two principle medieval images of edification, the "Mirror" and the "Way" which symbolically describe the process towards personal fulfillment. Likened to the mirror image, Bernanos' principal protagonists are a reflection of his own spirituality which drives him to decry, like the prophets, a milieu of lies, avarice and mediocrity. The central action becomes "the Way," a movement in one direction. It is a journey of faith towards genuineness 
and authenticity. Within the context of this medieval imagery, the simultaneously real and supernatural milieu of his characters is replete with paradoxical elements. Exterior landscapes reflect interior dispositions. Poverty, humility and simplicity are essential to spiritual wealth and wisdom. The darkness of fear and anguish is key to the light of joy and truth. Tension, struggle and battle are necessary to true peace.

Childhood, the hope of new life, is ultimately realized in death. In short, Bernanos' universe provides a familiar stage upon which each reader can define his or her own role. The bernanosian novel contains an ageless drama which is common to each individual. It is first and foremost, a creation which reflects the experience of the human condition, namely, a journey towards wholeness. Descriptions of human experience in an observable context can be more easily juxtaposed to various periods of history than those set within a particular spiritual context. In order to provide a context for identifying Christocentric characteristics of a medieval spirituality which emerge in Georges Bernanos' literary creation, the first chapter highlights the historical and devotional elements which influenced the imitation of Christ movement in the Middle Ages. Special attention is given to the main medieval images of edification: the Mirror and the 
Way. In Part Two of this study, these images provide a backdrop to the medieval Christocentric similarities discovered in three bernanosian novels, sous le soleil de Satan, La Joie, and Journal d'un curé de campagne.

\section{FORMATIVE ELEMENTS OF A MEDIEVAL SPIRITUALITY}

\section{A Fundamental Concept of Spirituality}

The First Part of this study which highlights some of the formative elements in the development of both a medieval and a bernanosian spirituality flows from a fundamental premise about the meaning of "spirituality." It must first be understood that the manner in which one chooses to proceed towards the Christian ideal, and the concomitant relationship with Jesus, effects the creation of a unique spirituality. The choice is dependent upon many factors. Chief among these is the fruit of christian faith. This is primarily the belief in God's personal action within the individual through the spirit, and the consequent capability of the person to respond to that action. And secondly, it is the belief that this action takes place in the person within the context of one's lived experience. Consequently, a whole range of influences is present in the formation of any spirituality, and likewise, in the development of a relationship. Gabriel Braso has aptly described the broad 
spectrum of factors which may affect the unique conception and realization of the Christian ideal, that is, the formation of a particular spirituality.

We can point out first of all the intellectual ability and the whole temperament of each individual. . . The degree of culture also has a great deal of influence on the means that will be chosen for the Christian life. So do the kind of life, the person's own status or condition, his experiences, the preference for some one concrete means of sanctification, the circumstances of time and place, the particular vocation which inclines one toward a certain proximate, immediate end (education of youth, practice of the works of mercy, bringing the gospel to unbelievers, apostolate to the working classes, contemplative life, etc.) and we might also add the environment, and, in a particular way, the formation received. (5)

The influence of history on spiritual movements likewise provides an ambiance for the shaping of one's spiritual experiences. Consequently, extrinsic forces must also be considered as influential factors to personal interior formation. 
The fact of living under the same circumstances of time and of place may give a particular spiritual orientation to the individuals of that epoch. Then we have a current of spirituality. In the course of the centuries various currents of spirituality have been forming in the church, originating almost always in great historical events or in the various circumstances that have characterized an epoch and have notably influenced the development of its spiritual Iife. (Braso 6)

Having underscored important concepts in the consideration of any spirituality, it is now relevant to pursue the discovery of similarities between a medieval spirituality and Bernanos' spirituality. The next step of this study is to explore some historical and devotional influences which contributed to the shaping of a medieval spirituality characterized by a Christocentric emphasis.

\section{The Medieval Mindset}

During the Middle Ages, the capacity for wonder initiated even the most uneducated into realms of symbolic meaning. Etienne Delaruelle alludes to this awe and its origins in his book, La Piété Populaire au Moyen Age. He says: 
Depuis longtemps le merveilleux était entré dans l'art et dans la littérature: il suffit de penser à l'hagiographie du Haut Moyen-Age ou à l'épopée celtique; avec lui nous avons affaire à un merveilleux qui est, si l'on peut dire, audelà de la vraisemblance; il consiste en une surenchère constante pour dépasser la vérité des choses. Nous connaissons d'ailleurs les sources de pareils récits: que l'on pense au folklore oriental, au gnosticisme et à d'autres. (463-64) This ability to see beyond the ordinary concreteness of sense perception was not a denial of reality. Rather, the medieval view was merely a different and more comprehensive way of perceiving the real. Carolly Erickson has described this "holistic" medieval world view as follows:

Medieval perception was characterized by an allinclusive awareness of simultaneous realities. The bounds of reality were bent to embrace--and often to localize--the unseen, and determining all perception was a mutually held world view which found in religious truths the ultimate logic of existence. This perception, which, where it is alien to modern consciousness may be likened to an enchantment, was encouraged by 
neoplatonist ideas of the power and number of noncorporeal beings, the presence of life in inanimate creation, and the significance of vision as a creative force and as a mode of human understanding. Medieval people lived in a perceptual climate in which noncorporeal beings were a familiar and to some extent, a manageable force, recognized alike in theology and popular culture. (27)

This type of mentality disposed the medieval folk to live out a simple faith. Their devotional spirit was motivated by a popular perception of God and his power which permeated every aspect of their experience. Biblical stories, particularly those that carried the aura of mysterious noncorporeal realities, were especially predominant "theological" influences. Accounts of angels and demons confirmed a common belief in a world of spirits present and active all around. The apocalyptic themes were captivating for a people who anticipated the end of time as imminent.

Coupled with Scriptural influences on popular conceptions, there were other mixtures of philosophical and theological ideas. Many of these rose out of ancient pagan sources. Among the many examples of antiquity which filtered into the medieval view of the world are 
Chalcidius' incomplete commentary on the Timaeus, and Macrobius' commentary on the Somnium scipionis (an excerpt from Cicero's De republica). This latter work was a principal reference work on dreams and visions, and presented a mixture of pagan and Christian concepts of creation. In a short excerpt from Macrobius' commentary, similarities to themes of imitation and likeness found in a later medieval emphasis on Christ's humanity can be identified. Likewise, as can be seen subsequentIy, the historical symbolism of "Speculum" bears a resemblance to this earlier passage:

God . . created from himself Mind. This Mind, called 'nous', as long as it fixes its gaze upon the Father, retains a complete likeness of the Creator, but when it looks away at things below [it] creates from itself Soul. Soul, in turn, as long as it contemplates the Father, assumes his part, but by diverting its attention more and more, though itself incorporeal, degenerates into the fabric of bodies.. (qtd. in Erickson 11$)^{2}$

\section{Medieval clerics and the Church}

The formation of early medieval spirituality was also influenced by the clerical world, education as well as 
emerging devotional practices encouraged by the Church. The sermons of travelling preachers and priests had their effect on "medieval perceptual attitudes" where "visions defined reality" (Erickson 29). This period was an era where opportunity for literacy was scarce among the common folk. Monastic schools and the universities were the main educational centers. Ordinarily, designated clerics and persons of noble status were among the elite who found these schools accessible. Consequently, it is understandable that many preachers were ill-informed. Coupled with their conduct which was often less than exemplary, their teaching was, needless to say, inadequate. To a people ready to observe the spiritual realm in every aspect of their natural world, the message of those uneducated clerics and self-appointed evangelizers was the only religious nourishment available. Replete with a conglomeration of theology, history and folklore, these sermons tended to add fuel to the superstitious and occult practices flowing from the people's belief in a divine power they needed to appease. Natural disaster, disease, war, (all heralds of death), and simply the daily hardships for survival, lent evidence to their belief in a super force that was more and more unmanageable. Adhering to popular pagan trends in what may be considered a subconscious effort to grapple with an 
often catastrophic environment, much astrological application, cosmological animism, linguistic imagery (especially allegory) were prevalent in the preaching of the day. Infiltration of these elements into some of the doctrinal developments in the Church was not uncommon. It was inevitable that unchanging circumstances of destitution, ecclesial degradation, feudal oppression and the lurking presence of the specter of death would have their effect on the mentality of the people. The potential mystical outlook of wonder gradually became bound by a certain fatalistic and indifferent attitude towards life and religion.

In the twelfth century, the medieval world was freed from this attitude of fatalism and indifference. The apostolic itinerant evangelizer brought a breath of fresh air and hope to the medieval spirit. These preachers provided their hearers with a balanced blend of symbolism and realism. Because they stressed themes of austerity, poverty, and Christlike virtues which they modelled in their own lives, they gave impetus to a renewed faith in God, and deepened reverence for all that was religious. Their sermons or "exempla" were direct and literal (Chenu 159). 3 With a goal to affect the conduct of their Iisteners, these mendicant preachers did not bypass the reality of death or the circumstances of daily experience. 
Still using visual and allegorical imagery, the new evangelizers incited the folk to a literal imitation of Jesus through a return to the Gospel. Instruction, with an aim to touch the emotions of the people, was their main methodology. Startling, humorous, frightening, and inspiring tactics were included in their effective anecdotal sermons.

Medieval reform movements were born primarily from the laxity of the Church which, as a literate force, held political as well as religious power in its historical milieu. Similar to Bernanos' era, the medieval world was comprised of those who rejected affiliation with the orthodox Church and monarchist structures (the Waldensians and the Cathar preachers) and others who remained obedient and loyal while living penitential lives based on the Gospel (the Humiliati). The earlier prophetic voice and actions of Joachim of Fiore (1145-1202) described by omer Englebert point to a bernanosian echo which fuses the polemic with compassion (58). 4

A noteworthy shift in medieval spirituality which emerged with the reform movement was the increased concentration on Jesus' humanity. This Christocentric attention led to devotional practices surrounding the Infancy and Passion of Jesus. A description of these two Christ events set within a medieval devotional context 
brings to light, not only the focus on the human Jesus, but likewise, the emphasis on the person of Jesus as the Mirror and the Way. This discussion establishes a pertinent basis for specific identification of parallels between medieval Christocentric characteristics and three main bernanosian characters: Donissan, Chantal and the curé d'Ambricourt.

Medieval Christology and Imitation: the Infancy and the Passion

The strong emphasis on the humanity of Jesus from which devotional practices evolved (particularly in the Liturgies of the Eucharist and the Hours) began in the eleventh and twelfth centuries.

In contrast [to the God of early medieval writers], eleventh and twelfth-century writers began to stress Christ's humanity, both in affective and sentimentalized responses to the gospel story (e.g., the devotion of Mary of Oignies to the Christmas crèche) and in a new compulsion to build into the Christian life a literal imitation of the details of Jesus' ministry. The fundamental religious drama is now located within the self, and it is less a 
battle than a journey--a journey toward God. (Bynum, Jesus 16ff.)

With the new emphasis on the humanity of Christ, a theological shift from concentration on the resurrection and last judgment to creation and incarnation took place. Consequently, great stress was placed upon the FatherCreator who makes us into his image and likeness. The concept was that basically, through the creation and incarnation, one was already rich in the promise of eternal life with God.

Humankind is seen as assured of its capacity for God by its very creation and by Christ's incarnation; it need not so much be captor slain or a rupture in the universe knit up as a nudge along a preordained journey. (Bynum, Jesus 17) The "nudge" was essentially a transforming love that moved the individual towards a restoration of the core of "likeness" to God in one's being which had not been destroyed by sin, but merely tarnished (Bynum, Jesus 17). Becoming an image of God meant being in union with the Creator.

How was such a union sought and achieved? For the medieval Christian, to move from "the experience of aloneness, alienation, emptiness, a personal suffering or loss of what is good and meaningful" to true authenticity, 
to that person which one was created to be, namely, an image of God, an openness to the grace of conformity had to be maintained (Bynum, Jesus 17). This was basically a willingness to follow Jesus, to be his disciple, to imitate him. Applicable to this medieval period are the words of John Boyle in the preface to the collection of studies in Imitating Christ. He says:

And 'following' Jesus . . does not mean merely obeying His command or patterning one's external actions on His, but living out the basic interior attitude of His life in union with Him. (Boyle in Malatesta vi)

Devotional trends nourished such a Christ-centered interior attitude. The Liturgy which included the Eucharist as well as the recitation of the Hours was a primary mode of religious instruction for the faithful.

A passivity and blind faith among the people characterized their participation in liturgical functions. Attendance at Sunday Mass was imposed even prior to the eleventh century. This holy and mysterious sacrifice was reverenced as the "terribile sacramentum" at which even the angels assisted in fear and trembling (Délaruelle 459). The Mass was the supreme weapon used in continual warfare against the demons, and the reception of communion was insurance against damnation. 
The respect given to priests at this period was in large part due to the awesome Eucharistic responsibility with which they were invested. This respect for the clergy was but another factor pointing to the privileged place of Eucharistic devotion among the pious faithful of this epoch (Délaruelle 460).

The recitation of the Hours, a daily and common practice of the faithful by the twelfth century, was another prominent devotion of the Middle Ages. With progressive additions to the original core of breviary texts, a more human Jesus and his Virgin Mother became the central figures of this devotion. Certain sections from the Gospels which were very familiar to the faithful were among these additions (Dictionnaire, La Barre 142). The passion according to St. John as well as the Hours on the Cross were Iikewise included (qtd. in Dictionnaire, La Barre $\mathrm{xxix}) .5$

To a people who relished the concrete image, the decorative themes which appeared in the breviary texts would have exercised a profound influence on the direction of pious devotion. Frequently, scenes of Jesus' early Iife such as the Nativity, the Message of the Shepherds, the Flight into Egypt as well as illustrations of His Passion and suffering were depicted. 
Both the Eucharist and the Divine office provided an accessibility to the word which nurtured the faithful's imitation of Jesus. In a period where greater focus was given to the Infancy and Passion themes due to the increased concentration on Jesus' humanity, his Person was made more tangible. Thus, imitation seemed not only a desirable response, but a feasible one. Most of the patristic predecessors emphasized various aspects of Jesus' life dependent upon current christological controversies (Dictionnaire, Noye 653-54).6

The devotion of the learned in the medieval period evolved from a greater personal intimacy through contemplation, the prayer of the liturgy, and the realism penetrating the scene of the Middle Ages. Particularly through the sermons of St. Bernard who reflected some of the teachings of origen, affectivity became the prayerful response par excellence in the contemplation of the Infant. of Bernard's writings, Noye comments:

C'est la première fois, semble-t-il, que 1'Enfant Jésus est contemplé avec cette recherche du détail, qu'on parle de lui ou à lui-même avec cette vivacité de ce ton d'intimité. . (Dictionnaire 658). Tenderness, kindness, poverty, humility and simplicity were recognizable in this accessible and attractive child. 
And in this recognition, one was called to imitation. A Child that could be held and caressed as represented in the "crèche" was a visible reminder of this call to imitation.

The second theme permeating the liturgy and devotional practices of the latter medieval period is that of the Passion. Some of the Fathers of the Church concentrated on the divine retribution aspect of this Mystery. Thus, imitation of Jesus' Passion and Cross was primarily for reasons of gaining salvation. Again, the renewed emphasis on the humanity of Jesus gave this devotion a new thrust as early as the tenth and eleventh centuries.

Within the monastic setting, this concentration on the Crucified is replete with the desire for union which entails an interior martyrdom. As in the devotion to the Infancy, affectivity plays an important role. And the reality of Christ on the cross is not primarily for the purpose of atonement. Rather, the suffering and death of Jesus are first and foremost a testimony of love, calling forth love.

The stirring in the twelfth century to return to the Gospel and evangelical poverty presented the reality of Jesus who was born poor, lived poor, and died in utter poverty. Consequently, medieval piety evidenced a 
recognition of the tie between the way of the Cross and religious poverty.

Also in the twelfth century devotion to the Passion, the Cistercian influence was very present. St. Bernard's writings again exemplify new trends in the devotion of the Cross:

Il enseigne que l'âme, par la méditation et l'imitation du Crucifié, parvient dans la charité à l'union intime et personnelle àvec le Verbe incarné. . . La passion de Jésus n'est pas seulement témoignage d'amour mais aussi exigence d'amour. . . L'Amour crucifié pénètre l'âme, la brûle et la consume jusqu'à la faire mourir à elle-même. C'est ce martyre intérieur qui mène à l'union mystique entre le Christ et I'âme qui cherche Dieu. (Dictionnaire, Di Bernardo 327)

The thirteenth century presents us with saints whose lives, in union with the sufferings of Jesus, reflected the poverty, the desire, the interior martyrdom, and the affective response which typified this medieval devotion. Without a doubt, both the themes of Infancy and the Passion which were expressed in the Liturgy of the Eucharist and the Hours could not be other than basic characteristics of a Christ-centered spirituality. 
Stemming from this renewed emphasis on the humanity of Christ, imitation became a predominant mode of living out the Christian life. To take Christ as the Exemplar par excellence was indeed the way to holiness as was the modelling of any person who had conformed himself/herself to Christ. The Carthusian, Guigo II, described his understanding of imitation as the fullest possible joining of one's self and life to Christ:

. . imitation proceeds from love. . Unless you love christ you will not imitate Him, that is, you will not follow Him. For He said to Simon Peter after He had tested his love: "Follow Me", that is "Imitate me". The feet of Judas may have followed Christ, but what his heart followed was avarice . . But christ must be followed with the love of our whole heart. . - Simon of Cyrene indeed carried the cross and followed Christ, but he did not share in the torments of the cross. We must follow christ and we must cling to $\mathrm{Him}$, and we must not desert Him, but from afar, because he was to deny Him. There was only the thief who followed Him to death upon the cross. (qtd. in Bynum, Jesus $101)^{7}$ 
In general, the monastic tradition upheld a concern for appearance before God and union with Him rather than the edification of one's neighbor. With the dawn of the Gregorian Reform in the eleventh century, and the canonical movement in the twelfth century, however, a new concept of modelling eased its way into the concern for progress towards God and "re-formation" of the image of God in man. Stress on "verbo et exemplo" in many canonical commentaries indicates that the individual person carried the responsibility in whatever he/she said or did, not only for the transformation of one's own soul, but also for the transformation of others. Thus, in all the canon was and did, he was both a learner as well as a teacher. He became a model for others as he was moved by grace to imitate the Model par excellence. This is demonstrated in a passage from Hugh of St. Victor in his work, De institutione, where he speaks of imitation and re-formation to new life.

But it should be known that unless wax is first softened, it does not receive the form, so indeed a man is not bent to the form of virtue through the power of another's action unless first through humility he is softened away from the hardness of all pride and contradiction. . - Moreover the shape of the seal presents to the 
present matter another consideration. . . For the figure that is raised in the seal, when imprinted appears concave in the impression in the wax, and that which appears sculptured inward in the seal is shown to be shaped convexly in the wax. Therefore what else is indicated for us in this except that we, who desire to be reformed through the example of the good as if by a certain seal that is very well sculptured out, discover in them certain lofty vestiges of works like projections and certain humble ones like depressions. . . Therefore what in them projects, in us ought to be impressed within; and what in them is depressed, is to be erected in us, because we, when we take their deeds for imitation, ought to make the lofty things hidden and the humble ones manifest. (qtd. in Bynum, Jesus 101) 8

The canonical emphasis which moved towards edification did not destroy the traditional monastic concept of growing in love through "identification with his neighbor's joys and sorrows" (Bynum, Jesus 48). Rather, the canonical trend built on the concept of service. Thus, the canon, through his discipleship, became in his person, his actions, and in his speech, a pattern for others. 
Images of Edification: the Mirror and the way

In the concrete and symbolic manner of medieval expression, the use of imagery is frequent. As has been stated, two images which contain connotations of likeness to God and imitation of Jesus are the Mirror and the Way. The Mirror was a common image used during the Middle Ages.

The image of the mirror holds a prominent place in the monastic contemplative tradition, particularly that of the Cistercian school of the 12 th century, e.g., William of saint Thierry, Mirror of Faith; Aelred of Rievaulx, Mirror of Charity. Within seven years of the composition of this letter, saint Bonaventure used the same image in The soul's Journey into God. (Armstrong 204)

The general meaning behind the mirror image was to "show the world what it is and. . to point out what it should be" (Bradley 100).9 Earliest connotations referred to the mirror as symbolizing the religious ideal contained in Scriptures. In "looking" into them, one could see oneself in truth, and likewise see all that one was meant to become in terms of authenticity and wholeness. The mirror was a paragon, an example of what one was to become. The very "looking into" effected the change, the restoration 
and transformation of the person into holiness. "Here lies the knowledge of true blessedness; for therein, as in a mirror, man may consider himself, what he is and whither he goes" (Bradley 102). Of the early connotations of the mirror image, the religious significance is repeatedly emphasized. One such example reads:

In the reading of the Holy scriptures is the knowledge of divine blessedness. Man can consider himself in them as in a mirror: he can see what he is and what he aims at. Attentive reading purifies the soul . . (Bradley $102)^{10}$

All of these early connotations are reminiscent of the religious, historical themes of this period concerning the image and likeness of God, and the imitation of Jesus. The way is a thematic image drawn from Biblical origins. Referred to as the "Via Regia" or "royal road", this theme has its roots in the Book of Numbers $(21: 22)$. There, the sojourn of the Hebrew people leads them to confront Sehon, the Amorrhite king. In the old Testament text, the messengers of Israel say:

Let me pass through your land; we will not turn aside into field or vineyard; we will not drink the water of a well; we will walk the royal 
road, until we have passed through your territory. 11

The concrete meaning of "royal road" designating a public way which is straight and direct, has connotations akin to imagery of the ancient world. An early symbolic meaning applied by Greek philosophers was that of the soul on its journey to a God who waits for humankind in the kingdom. Interpreting the old Testament in light of the New was a common exegetical practice in the early Church, and particularly in the medieval period. Consequently, this theme of the Way gradually became Christianized by such authors as origen, Cassian and St. Benedict. According to Jean Leclercq, monastic life eventually became the royal road, a safeguard from deviation and distraction in this life's journey (The Love 131-32). Leclercq refers to an ancient sermon which expresses this meaning:

- - in an ancient sermon on the perseverance of monks, the symbolism is applied to what is proper to the cloistered life: its contemplative character; the temptation a monk must avoid is to engage in the occupations of the active Iife. (The Love 132$)^{12}$

The abbots of monastic orders were expected to set the example in pursuing the royal way. St. Bernard adheres to 
this same principle, and advocates poverty as an effective means to avoid detours.

With the medieval emphasis on the desire for the heavenly kingdom, the way took on broader meaning. It became an image of the whole church on the move towards the heavenly Jerusalem.

$$
\text { In the twelfth century, this eschatological }
$$

pilgrimage found its concrete expression in the dangerous and dusty expeditions of fervor and penitence. Its symbolism resided both in the spiritual motivation of imitating Christ's way of the Cross, as well as in the unseen realities represented by the sacred places of destination.

Elle demeurait essentiellement un exercice d'ascèse. Car les voyages, en cette époque, étaient pénibles, fatigants, pleins de risques de toute sorte, en particulier lorsqu'il s'agissait d'aller en Terre Sainte, alors dominée par les musulmans. . Dans ces conditions la prudence semblait requérir qu'on ne partit point seul. Mais que l'on fût seul ou en groupe, que l'on fût en pèlerinage ou en pérégrination, le voyage n'était une joie que pour l'esprit; il ne ressemblait en rien à un agréable tourisme. Il supposait toujours, au 
point de départ, un détachement radical, absolu - Il s'agissait toujours de rechercher ia pénitence, la pauvreté, l'humilité, de s'associer au mystère de la croix par un accomplissement de plus en plus total du renoncement inclus dans la vocation monastique. (Leclercq, "Monarchisme" 40-41) 13

It is possible that the attraction to special places of pilgrimage was, at least for the devout, due to faith in the abundant graces received from such an ascetical venture. Like the chivalrous knight who risked all in the quest for honor, the pilgrimage was a search for christ, the Way (Vorreux 9).14

\section{Chivalry and the Quest}

The lust for power and expansion which characterizes war of all ages was ever-present in the medieval period. From the reverberations of the barbaric invasions, to the religious wars of the crusades, to the defense of feudal lords, to the control of the communes by the newly formed class of "bourgeois," the medieval period is marked by a history of rivalry. However, this age of violence and corruption was accompanied by a flourishing of spiritual illumination, aspiration and achievement. 
- . no wars and dissensions could stop genius which everywhere was at work praying, thinking, writing, singing, building, carving, painting, busy with every art and every craft. Each generation handed on a wonderfully increasing inheritance in the small cities just as much as in the great, and the world was being enriched by something very rare and beautiful. (De Robeck 12)

Chivalry was part of this inheritance which was marked by a continued combination of the symbolic and the real. The symbols and ideals of chivalry, expressed in art form as well as in modes of actual living, became the fabric of the medieval social structure. Exalted in the epic storytelling of the wandering bards and minstrels, the feats of a Roland, of a Launcelot, of a Parzival, were undoubtedly known even to the common folk. The adventure, honor, bravery and valor of knighthood found inspiration in a Lady love. This woman, wonderfully real, yet mysterious and symbolic, was the center of lyrical poetry sung by the troubadours, trouvères and jongleurs in the courts of kings and nobles (Leclercq et al. 280). The realism and symbolism inherent in the inseparable trends of chivalry and courtly love are alluded to by Arnaldo Fortini. 
The valor of the knight could not exist without being aroused and fed by the love of a woman. Love was the lyrical force in all battles, the fervor that made all bravery sublime, the passion that changed bitter pain into joy. The fate of peoples and of kingdoms was decided on the field by the memory of a luminous smile and the rustling of a soft embroidered scarf. Launcelot of the lake taught that the true knight must have strength, prowess, loyalty, kindness, gentleness, courtesy, generosity, prodigality, and an abundance of friends and of riches. But all this would have been like a bare garden in the middle of a winter night if it were not warmed and made to flower by the sun of love. (181)

Chivalry, which only began to wane in the latter part of the thirteenth century, was a symbolic ideal present in a warring societal structure. But it found concrete expression, not only on the battlefield, but through the Church. A rite of blessing which conferred knighthood sanctioned the right of the soldier to bear arms and to defend himself and the weak. The ceremony as described in a tenth century ordo includes the bishop's blessing of the standard, the lance, and the sword; the prelate girded the 
knight with the sword and presented him with a shield. 15 The whole ceremony of "dubbing" to knighthood was replete with prayers and antiphonal chanting.

Initially, knighthood was the privilege of everyone as it flowed from the universal character of the Gospel message. However, by the end of the twelfth century, knighthood was reserved for nobility. In perceval le Gallois, Chrétien de Troyes proclaims:

The highest order that God has made is the order of Chivalry, which must be without baseness. (Leclercq et al. 278) 16

Its mystical overtones as evidenced in the legendary images of the quest for the Holy Grail, endowed knighthood with the purity of heart and perfection of the shining virgins and martyrs. In an era of desire for the heavenly Jerusalem, fidelity and service to the king of heaven was represented through fidelity and service to a feminine intermediary such as the Virginal Queen and Mother. Piety towards our Lady, who was a reflection of purity and maternity, was integral to the later medieval conception of the "lady." She often became the embodied ideal and source of inspiration for the knight on his quest. Not only for the knight, but likewise for the medieval Christian, the quest became a journey towards the perfection modelled by the Virgin Mother and the saints. 
They were the spiritual beacons of the faithful whose daily adventure was the call to imitate the human as well as divine Model for all, Jesus.

In an attempt to provide a foundation for a subsequent discussion of similarities to medieval Christocentric characteristics in three of Bernanos' novels, Sous le soleil de Satan, La Joie and Journal d'un curé de campagne, this chapter presented some of the formative elements in the spirituality of the Middle Ages. Premised on the assumption that a faith response is at the core of a "spirituality" which can best be considered within a combined personal and historical context, this discussion first presented elements of the medieval mindset. The incorporation of the supernatural into ordinary happenings of daily living, the positive and negative influences of the clerical world as well as ecclesial trends of devotion and doctrine are among the common elements to a medieval as well as to a bernanosian journey.

The focus on the Incarnation in the twelfth century, inspired devotion to the Infancy and Passion of Jesus. The imitation of Christ especially found its expression through two main images of edification: the Mirror and the Way. Jesus' human qualities of tenderness, poverty, humility and simplicity were particularly modelled. 
Chivalry, a movement which united societal and ecclesial trends in mystical idealism, introduced additional exemplars. The fervent pilgrim ready for martyrdom, the knight whose purity of heart prepared him for the quest, and the Virginal Queen and Mother exemplified other virtuous qualities for imitation. 
NOTES

1 One such reference is found in the introduction of Daniel Morris', From Heaven to Hell, a study on imagery in bernanosian fiction. Morris describes Georges Bernanos' world view as "one that venerates the Middle Ages when the Catholic church and royalty held a position of respect and authority" (4). He also states that "the frequent, direct opposition in his novels between the forces of good and evil strikes a familiar chord in Medieval literature" (5).

2 Erickson cites: Macrobius, Commentary on the Dream of Scipio, trans. William H. Stahl, Records of Civilization, xlviii (New York, 1952) 143, 221.

3 See also Erickson, The Medieval Vision 78, and Delaruelle, La piété 142 .

4 Omer Englebert, Saint Francis of Assisi, A

Biography (Michigan: Servant Books 1979) 58.

This pure and gentle man had a burning love for Christ. He had a deep love for and feeling of kinship with nature; he tenderly rested the faces of the dying against his breast to warm them and to make dying easier; he lived in destitution, professing that nothing brings man close to God like voluntary poverty; and he showed much distaste for useless learning. 
5 La Barre, "Heures (Livres $D^{\prime}$ )," xxix.

Private prayers were not excluded from this medieval

formation of the Hours. Of these prayers, V. Leroquais (cited by the author) has remarked:

C'est peut-être la partie la plus riche, la plus pittoresque et la plus variée, celle où se reflète le mieux l'âme du moyen âge. Ce qui lui donne une saveur particulière, c'est qu'on y rencontre. - le plus souvent la prière extraliturgique, la prière privée, celle qui a jailli spontanément de l'âme populaire qui a traduit, à un moment donné, ses besoins et ses aspirations.

6 Irénée Noye, "Enfance de Jésus (Dévotion)," Dictionnaire de spiritualité ascétique et mystique doctrine et histoire, $1960 \mathrm{ed}$.

Some of these controversies can be identified as docetism, marcionism, manichaeism, etc. Perhaps exceptions to the great emphasis on the Divinity of Christ during the formation of doctrine in the Early Church were found in the works of Origen and St. Leo the Great. Noye describes the "affective" approach of origen. He says:

Origène ne se contente pas de proposer en modèle la foi des bergers; il essaie de faire partager cette intimité presque familière et cette 
ferveur dont il est animé envers "son" Seigneur, "son" Christ. (653)

In St. Leo's works, Noye highlights the emphasis on the interior affective attitude. This becomes apparent in the response of the faithful as the humanity of Christ becomes the prime focus in the medieval period. Noye says:

- . il semble cependant l'un des premiers à établir explicitement le lien entre l'enfance de Jésus et l'esprit d'enfance (Sermon 37, PL 54, $258) \cdot(654)$

7 Also see footnote \#45: Guigo, Meditations, chap. 10, Lettre, ed. College and Walsh, 184-88, lines 100-26; trans. College and Walsh, Ladder 135-33C.

8 See footnote \#36: Hugh of st. Victor, De institutione, chap. 7, PL 176; cols 932D-33C.

9 See also footnote \#5: Saturday, 30 January 1779, in The British Essayists, ed. A. Chalmers (Boston, Massachusetts, 1856) XVIII, 26.

10 The religious significance of the mirror imagery also contained the idea of contemplation. In the medieval classic, The Divine Comedy, Dante includes this image in the dream of Leah. While Leah is the old Testament representative of the active life or well-doing, Rachel represents the contemplative life or "the knowledge of God." In Canto XXVII, one reads: 
Know, whoever asks my name, that I am Leah, and I go plying my fair hands here and there to make me a garland; to please me at the glass I here adorn myself, but my sister Rachel never leaves her mirror and sits all day. She is fain to see her own fair eyes as I to adorn me with my hands. She with seeing, and I with doing am satisfied.

(Dante Alighieri, The Divine Comedy, 2:Purgatorio, trans. John D. Sinclair (New York: Oxford University Press, 1981) 355 .

In his commentary on this dream, sinclair refers to a citation by J.S. Carroll which recaptures this same medieval theme of the active/contemplative life. st. Gregory the Great, when the office of the Papacy was forced upon him, bewailed the loss of his Rachel, the quiet life of contemplation in his monastery: 'The beauty of the contemplative life I have loved as Rachel, barren indeed but clear-eyed and fair, which, although by its quiet it bears less, yet sees the light more clearly. Leah is wedded to me in the night, the active life namely, fruitful but blear-eyed, seeing less though bringing forth abundantly.' (362) 
11 The translation in the Revised Standard Version Common Bible reads: "We will go by the King's Highway."

12 see footnote \#73: "Sermon ancien sur la perséverance des moines," Analecta monastica II, 24, 11923.

13 See also Dante, The Divine Comedy, 2:Purgatorio, Canto I, 25.

Here this medieval poet captures the sense of penitence and aloneness of the pilgrim. "We made our way over the lonely plain, like one who returns to the road he has lost and till he finds it, seems himself to go in vain." In John Sinclair's commentary on this verse, he states, "the first finding of the way in the life of penitence is a solitary and perplexed experience" (29).

14 In the medieval period, the life of St. Francis of Assisi is a marvelous example of the concrete and symbolic meanings of the medieval pilgrimage. As a pilgrim, he visited Rome, the shrine of St. James of Compostella and Jerusalem. Vorreux speaks succinctly of both the interior and real meaning of the journey for this saint, a prime Christ model of this historical period:

Quête du Christ sur les routes et dans les sanctuaires. . traduction de cette autre quête, plus intérieure, qui le poussait à "suivre les pas du seigneur." 
15 The shield carried the insignia of the church of the kingdom which the knight would loyally serve. The shield, in the tradition of animism, was often described as the faithful companion of the warrior.

16 see footnote \#153. Chrétien de Troyes, Perceval le Gallois, line 2831 (ed. C. Potvin, vol.I). 
CHAPTER II

FORMATIVE ELEMENTS OF BERNANOS' SPIRITUALITY

The second step in this study is to provide a relevant description of Bernanos' external milieu and of his lived experience within his particular historical circumstances. This biographical overview which emphasizes key elements of his spiritual formation provides a context for understanding not only the spirituality of Bernanos, but also the Christ figures of his novels. Elements common to the formation of a medieval spirituality are numerous in the bernanosian journey. The merging of the supernatural into daily Iived experience, positive and negative influences of the clerical world, devotional and ecclesial reinforcement of Christocentric belief and imitation, obedient conformity to a God of love, and a quest which demands the virtuous integrity of the medieval knight all figure in the life experience of this author.

Bernanos' Childhood and the Medieval Mindset

Bernanos' life was a continuous journey in the real dimension of daily lived experiences. But each step of his life was likewise an ongoing pursuit of invisible realities. His "Weltanshauung" was one of wonder which equipped him with the imaginative ability to materialize his dreams through his writing and make them live in the 
concrete world. His creation gives testimony to this capacity.

La grandeur de Bernanos réside précisément dans ce don de rendre concret, à travers les personnages, les situations, les descriptions, ce qui est essentiellement invisible, hors de ce monde. . Le côté transcendant de Bernanos le visionnaire ne l'empêche point . . de créer dans ses romans d'une force irrésistible un monde actuel physique. (Reck 80 )

To glimpse the origins and early foundation of this author's integrated world view, we turn to his earliest years. Although Paris was Bernanos' birthplace on February 20, 1888, the countryside of Artois in the region of Pas-de-Calais was the playground of his childhood. With affection, he describes the little village of Fressin and the large old house which his father, an interior decorator, purchased for the family.

J'habitais, au temps de ma jeunesse, une vieille chère maison dans les arbres, un minuscule hameau du pays d'Artois, plein d'un murmure de feuillage et d'eau vive. La vieille maison ne m'appartient plus, qu'importe! Pourvu que les propriétaires la traitent bien! Pourvu qu'ils 
ne lui fassent pas de mal, qu'elle soit leur amie, non leur chose:. . (qtd. in Béguin 20)1

Bernanos' genealogical origins as well as hints of formative events in his early childhood are revealed in his own polemic pieces and letters, as well as in reminiscent accounts of those who knew him personally. Albert Béguin succinctly summarizes a somewhat sketchy family tree:

- . même si la légende familiale parle d'origines espagnoles et d'un aieul flibustier, conquérant de Saint-Domingue où ses descendants auraient véçu longtemps, toutes les ascendances connues sont de vieille terre française, lorraines du côté paternel, berrichonnes du côté maternel. Le grand-père Bernanos est venu, premier de sa race, de Bouzonville, aux environs de Metz; la mère a quitté Pellevoisin d'oú ses ancêtres paysans n'étaient jamais partis, sans doute, depuis des siècles. (20)

Through his modest peasantry origins and his early provincial surroundings, Bernanos gleaned an appreciation for the ordinary. For both his spiritual and imaginative formation, he owed much to his mother's influence. When questioned about his religious formation, he gave credit to his mother. 
- . il l'a tenue [sa formation religieuse]

exclusivement de sa mère, et c'est d'elle aussi qu'il devait hériter son très humble sentiment du métier, de la tâche à accomplir, et de ce qui, dans le labeur humain, demeure toujours à recommencer. $(26-27)$

In Nous autres Français, Bernanos provides more insight into the positive maternal influence in his iffe:

Nous avons été élevés par de trop bonnes mères, trop patientes, trop courageuses, si dures à la besogne, si dures et si douces, avec leurs tendres coeurs vaillants, inflexibles. 'On n'en a jamais fini!' disaient-elles. C'est bien vrai qu'on n'en a jamais fini. Quand les jours sont trop courts pour le travail de tous les jours, il n'y a pas de quoi être fiers! (qtd. in Béguin $27)^{2}$

The early years in Fressin provided experiences of childhood freedom. Adventures of real and fantasized explorations on unending pathways, mischievous escapades of neighborly poaching and hunting blackbirds, hidden hours of precocious reading of Balzac, Barbey d'Aurevilly and a host of other authors, preaching to a pretend congregation are glimpses of early experiences reflected 
both in his polemic writings and in his fiction. 3 older people from Fressin remember Bernanos as

- - un petit garçon bien découplé, mais aux nerfs fragiles, séduisant et déjà conscient de sa séduction, capable de jouer pendant des heures de grandes scènes de supplication pour obtenir d'une paysanne la carabine de son mari et aller s'exercer à la chasse sur les poulaillers des environs, avant de poursuivre un gibier plus sauvage. Mais certains évoquent aussi l'enfant grimpé au sommet d'un sapin pour Iire, ou bien pour chanter la messe et adresser à des fidèles imaginaires d'interminables sermons. (Béguin 28)

A most significant spiritual event during Bernanos' childhood which profoundly influenced him for the rest of his life was his first communion. Shortly before his death in July 1948, he revealed how his experience of this sacramental moment played an important role throughout his life. To l'abbé Pézéril he confided:

Depuis longtemps--à cause de ma jeunesse maladive et des précautions qu'on me faisait prendre--je crains la mort, et par malheur, peut-être mon ange gardien dirait par bonheur, j'y pense toujours. La plus petite 
indisposition me semble le prélude de cette dernière maladie, dont j'ai si peur . . Quand j'étais tout petit encore, et que je pensais à ces choses, je me disais que la vie était longue, et qu'en la remplissant de toutes sortes d'aventures, de gloire, de renom, de puissance, on pouvait la rendre si heureuse que cela valait la peine d'un peu de souffrance, à la fin... Au moment de ma première communion, la lumière a commencé de m'éclairer. Et je me suis dit que ce n'était pas surtout la vie qu'il fallait s'attacher à rendre heureuse et bonne, mais la mort, qui est la clôture de tout. . . Ce que je veux dire, en me disant revenu aux idées de ma première communion, c'est que je reconnais plus que jamais que la vie, même avec la gloire qui est la plus belle chose humaine, est line chose vide et sans saveur quand on n'y mêle pas toujours, absolument, Dieu. D'où il m'apparâ̂t logiquement que, pour être heureux, il faut vivre et mourir pour Iui, aidant à ce que son règne arrive selon votre âge, selon votre position, vos moyens, votre fortune, vos goûts. Et ainsi je n'aurai plus peur de cette affreuse mort. (qtd. in Béguin $31-32)^{4}$ 
The religious experience which Bernanos describes here is central to his unique spirituality. The richness of this experience unfolds as Christocentric themes are discussed in subsequent chapters. For the immediate purpose of this study, it is important to note that Bernanos' ability to marvel at the ordinary and to perceive the supernatural, God and his messengers, in daily realities is reminiscent of the medieval mentality.

\section{Clerical and Ecclesial Influences}

Perhaps Bernanos' childhood play of clerical imitation flows from the frequent presence of priests in his home. Béguin intimates that the number of photographs of clerics found in the ruins of the Fressin home is verification that several of these pastoral figures were guests of Bernanos' parents, Emile and Hermance Bernanos. Béguin refers to these pictures and speculates about the effect of a clerical presence on the child Bernanos, a keen observer even at a very young age.

- . un bon quart sont des portraits de prêtres, amis de la famille. . C'est sur ces visages de prêtres qu'a dû se lever bien souvent, scrutateur, déjà habile à déceler la personne derrière ses signes apparents, le regard d'un enfant solitaire. (27) 
Béguin further elaborates on this influential presence as he recalls the negative aspect of clerical encounters during Bernanos' youth:

Mais ce qui ne doit pas être oublié, c'est que de bonne heure les regards de cet enfant se levèrent souvent, non seulement sur le visage des prêtres amis, venus en hôtes dans la maison paternelle, mais aussi sur le visage détesté d'autres prêtres, ses éducateurs. (35)

Bernanos' first encounter with formal education (1898-1901) was not pleasant. Placed in the Jesuit school situated on Rue Vaugirard in Paris, far away from the charmed comfort of his familial environment, this young pupil experienced his new academic surroundings as hostile. Confronted with this perceived reality, he armed himself with rebellion.

Il se rendait systématiquement intolérable, mal tenu, malpropre exprès,--tel exactement qu'on ne le vit qu'à un autre moment de son existence: au front, pendant la guerre. (34)

In an interview in 1938, Bernanos would comment on the horrors of the academic system inflicted upon him as a youngster. This negative experience fueled his already sensitive spirit with scrupulous tendencies. 
. . semblait uniquement construit pour vous prendre en defaut, pour cultiver la mauvaise conscience et, vous rappelant des vacances au moment même où la douce illusion de la liberté commençait à naître, vous tançait, retenait, punissait; on était sans défense, exposé, désarmé . . Il m'en est resté le souvenir d'une vraie panique! (34)

After two years of this pedagogic persecution, Bernanos' parents enrolled him in the Petit Séminaire Notre-Damedes-Champs, then in the Petit Séminaire Saint-Célestin de Bourges where he excelled in humanities and thrived under the direction of l'abbé Lagrange. Much later, in a letter to his wife, Bernanos would describe another cleric who influenced his spiritual life profoundly:

J'ai reçu hier un des billets de Dom Besse. Enfin! j'ai trouvé un mâttre et un commandement. - . Le terrible et calme moine m'est entré rudement dans le coeur, par effraction. (qtd. in Béguin 103) 5

Young Georges' polemic spirit, which staunchly sided with loyal monarchists, emerged in early debates with teachers and democratic classmates at the Collège SainteMarie d'Aire-sur-la-Lys in Pas-de-Calais. Undoubtedly, the early spiritual formation of his home life was 
reinforced, at least formally, in these religious institutions. Horariums which provided a central place for sacramental and prayerful observance according to the Iiturgical calendar of the Roman Catholic tradition included such exercises as daily Mass, recitation of the Hours, the rosary, examination of conscience and other pious practices. The effect of these practices on an individual's spiritual development is not measurable. Such routine devotions may only be external markers or guideposts to which a person may adhere when confronted with the exercise of one's faith, that is, belief in the face of an indescribable emptiness. Bernanos' appreciation for these ritual acts of the religious tradition which he inherited, embraced and defended loyally, is evidenced by his practice of them. A few citations from letters in his adult years reflect the continued importance of these devotions in his life. --Das de messe, ma chérie: un dimanche bête. (qtd. in Béguin 103) 6

--Il faut avoir dit son chapelet dans ces ténèbres pour savoir ce que c'est que la Salutation angélique . . . Et ce "Magnificat" éblouissant que je récite chaque soir et qui purifie l'air autour de moi! (qtd. in Béguin $106)^{7}$ 
Again, it cannot be forgotten what a profound effect the sacrament of the Eucharist had on Bernanos. The consolation he describes at the time of his first communion provides a glimpse into a spiritual orientation which is consistently revealed throughout his life. His center of balance is the teaching authority and sacramental Iife of the Church. Bernanos embraced the belief that the church is the body of christ. As the custodian of truth, Holy Mother Church represented for him the perfection of Christ. This mystery of the incarnation, "the Word made flesh" is not an inaccessible and glorious "Verbe en Majesté" but the human Jesus whose life can be imitated. Bernanos sought refuge in the love of God made real through the birth, passion and death of His Son. According to Hans Urs Von Balthasar, the Incarnation, the mystery of a poor and humble God as opposed to a majestic deity, was indeed at the core of Bernanos' spirituality.

- Pas dans le Verbe en Majesté . . le Verbe s'est fait homme, enfant qui a prié et souffert, qui contient en lui la voie tout entière de I'homme, de l'enfance à la mort, précisement parce qu'il est plus faible qu'un enfant et plus abandonné qu'un moribond, et qu'il est devenu ainsi la mesure même de 
l'existence et le juge de toute chair. . $\cdot(144)$

Equal to the authentic reformers of the medieval epoch, Bernanos is remembered as a loyal witness to the spiritual and a compassionate prophet to the temporal. Mais ce témoignage mystique et christique a aussi une dimension sociale et politique. C'est une dimension non point conservatrice mais une dimension prophétique qui atteste la volonté de Bernanos de répondre au problème posé par la misère moderne. (Beaumont 82)

This simultaneous spiritual and temporal side of Bernanos identifies him as a modern Christian model for imitation. His adherence to the reality of the incarnate christ, his own model to imitate as the way to eternal life, recalls the primary focus in the evolution of medieval spirituality.

Bernanos: Witness and Knight

Juxtaposing the life of Bernanos to the broad meaning of the medieval imagery of the Mirror and the Way, and its connotations of Christ-like imitation, parallels are readily recognized. The events of his life continually form and reflect the person he becomes. His adolescent and adult years can literally, as well as figuratively, be 
characterized as a life "on the road." His pilgrimage is marked by other familiar medieval resemblances. Bernanos, the warring knight, possesses the characteristics of "la courtoisie" complete with the driving forces of staunch character, love and adventure that sparked the quests of so many centuries ago. Akin to the medieval hero whose innocence was a prerequisite to election for a special undertaking, Bernanos' adolescence was marked by a gradual awakening to his own calling. It is his "fidélité à l'esprit de l'enfance retrouvé pendant l'adolescence" which perhaps attuned him to "sa véritable vocation: devenir un témoin du Christ, mais un témoin läque, engagé dans l'action temporelle" (Estève Deuvres xli). His engagement in the temporal world was expressed in different ways.

Bernanos' student years in Paris between 1906 and 1913 found him passionately and politically vocal, particularly in defense of L'Action Française. He experienced the turbulent demands of idealism which led him to participation in demonstrations, plots to reestablish the monarchy, and consequential imprisonment. From a letter written while in prison, one can glimpse Bernanos' determined conviction to follow his ideals at all costs. 
Au moment où j'écris ces lignes (derrière les murs de la Santé), un gardien s'efforce à ma porte de pousser les verrous; mais il a beau faire. Le geste inutile et bruyant m'a rempli le coeur, non point du sentiment de mon impuissance, mais d'une orgueilleuse liberté. Je rends grâce à ma conviction d'avoir si bien tout ordonné en moi, que chaque événement de ma vie me pousse à elle, et elle à mon but. Tel est le privilège des âmes organisées. Le troupeau des rhéteurs peut en rire: je souhaite à tous les écrivains tiraillés de désirs divers, à toutes les âmes menacées de dissolution, une discipline mentale de camelot du roi. (qtd. in Béguin 97) 8

Eventually, Bernanos' chivalrous loyalty turned to a different type of action. By 1909, he wields the sword of the idealistic warrior through the written word. At Rouen he was the editor of the monarchist weekly, I'Avant-Garde de Normandie, through which he vigorously attacked the philosopher Chartier.

With the declaration of war in 1914, Bernanos became a warrior in reality. He voluntarily joined a regiment where he experienced first-hand the horrors of front-line battles. Solitude, poverty and woundedness were harsh 
realities which matured Bernanos' youthful idealism. His letters of this period reflect the attitude of a loyal soldier whose words reveal temperance in his energetic battle with external forces. The sobering facts of war led him in the direction of an internal personal quest. In a letter to his fiancée in 1916, he wrote:

Plus de fantaisie! Ai-je dépensé d'un coup, en des temps anciens, toute celle que Dieu m'avait départie? Ou bien la guerre l'a-t'elle tuée?. - Je travaille dans la nuit la plus opaque, je me bats avec les images et les mots d'une bataille extraordinaire, chaque page écrite me coûte un monde. J'espère que ce n'est qu'une épreuve du Bon Dieu, qu'il a mis seulement un bandeau sur mes yeux et que je ne donnerai pas le jour à un monstre de noire mélancolie, mais à une belle et lumineuse chose, pareille à celles que j'ai tant aimées! (qtd. in Béguin 101) 9

Bernanos' real experience of war was a first-hand awakening to the overwhelming realities of suffering, poverty and death. The idealistic drive for honor, adventure, and victory of the contemporary soldier were not unlike the medieval crusader or chivalrous soldier whose efforts for conquest and fortune often ended in martyrdom. Other characteristics of medieval chivalry are 
strikingly observable in the life and works of Bernanos. These traits reflect central aspects of his spirituality, and particularly bring to the fore marks of an unquestionable Christian attitude. One description of this contemporary knight very aptly captures his courtois and chivalrous spirit.

$$
\begin{aligned}
& \text { Un 'chevalier,' un gentilhomme 'au regard bleu } \\
& \text { et au rire éclatant,' un croisé, a-t-on dit. Un } \\
& \text { croisé, dont la devise serait: 'La Charité ou } \\
& \text { l'Enfer.' Mais n'oublions pas l'Honneur dont } \\
& \text { Bernanos s'est fait l'ardent défenseur, et, à } \\
& \text { côté de l'honneur, la lucidité. (Brodin 154-55) }
\end{aligned}
$$

Bernanos always hoped for a reawakening of the sense of Christian honor among all peoples. For him, this virtue was a unifying factor between the holy and the secular. Consistently moving in both a temporal and spiritual domain, Bernanos concisely describes the double plane of honor in Les Grands Cimetières sous la Lune.

Il $\mathrm{y}$ a un honneur chrétien. . Il est humain et divin tout ensemble. . Il est ia fusion mystérieuse de l'honneur humain et de la charité du Christ. (qtd. in Brodin 143)

This love of Christ is Bernanos' ultimate driving force. Just as knightly love and loyalty in the service of the Most High Lord was, for medieval saints, directed 
and inspired by a mystical and allegorical ideal such as the Lady Poverty of St. Francis of Assisi, Bernanos' ideal can be identified by asking the question, "Whom did he obey?" The eulogy given by l'abbê Pézéril at Bernanos' funeral provides one clue to the allegiance of this modern day knight.

Celui qui est aujourd'hui êtendu parmi nous et que la mort $n^{\prime} a$ pu que saisir dans l'attitude du chevalier, s'est endormi entre les mains de l'Eglise comme un enfant. . . Il avait la passion de l'ordre et celle de l'obéissance. Peut-être par impatience d'adhésion. Mais surtout, et essentiellement, parce qu'il y a sur terre une réalitê qui est cet ordre et permet cette obéissance: l'Eglise. (12)

Certainly, Holy Mother the Church was revered by Bernanos. He saw her as the unifying repository of a twofold dimension: spirit and flesh. On the one hand, she required filial obedience, a sincere love of the truth which she revealed and belief that she was simultaneously spouse and body of Christ. In her spiritual dimension, she was the heart of the communion of saints, and most profoundly, the center of his profound allegiance--divine love. On the other hand, in her human dimension, she required free judgment, criticism and humiliation. For 
Bernanos, the Church was the means by which the quest would be fulfilled for she was the guardian of truth. The treasure sought was truth, the reality which makes one free.

Si l'Eglise est vraie, il faut lui obéir sans poser de questions (tout marchandage envers l'obéissance due à l'Eglise manifesterait une absence de foi et serait une sottise), mais cette obéissance ne peut être qu'une libre obéissance et qui aille dans le sens même de la liberté, car vérité et liberté ne sont qu'une seule et même réalité. (qtd. in Von Balthasar 76,10

Freedom in this sense is the key to authenticity and wholeness. It is the portal of human perfection, which, within the Church, is to imitate the perfection of Christ.

In the Church's tradition, the perfect human reflection of Christ was Mary, the Mother of God. Bernanos captures the sublime and human qualities of this medieval ideal in his praises of her through one of his characters, the curé de Torcy. Her purity and innocence model the requisite qualities of the true knight. Bernanos incorporates mirror imagery into his description of her. Strongly reminiscent of the connotations of the medieval mirror, this Holy Virgin Mary can no longer see 
herself as a reflection because, in her purity, she has become one with the image.

Elle est la mère du genre humain, la nouvelle Eve - . cette reine des Anges! Et elle l'est restée, ne l'oublie pas! Le Moyen Age avait bien compris ça, le Moyen Age a compris tout. . - la Sainte Vierge n'a eu ni triomphe ni miracles - . Personne n'a vécu, n'a souffert, n'est mort aussi simplement et dans une ignorance aussi profonde de sa propre dignité, d'une dignité qui la met pourtant au-dessus des Anges. Car enfin, elle était née sans péché, quelle solitude étonnante! Une source si pure, si limpide, si limpide et si pure, qu'elle ne pouvait même pas y voir refléter sa propre image, faite pour la seule joie du Père. . . ( JCC 1192-93)

\section{The Pilgrim's Quest}

The adult years of Bernanos, the "chevalier," were marked by a determined pursuit of his quest, innumerable wanderings, many trials and many joys. His marriage to Jeanne Talbert d'Arc was blessed with six children. old and new friendships continued to support and encourage him spiritually and professionally. With the successful 
publication of Sous le soleil de Satan in 1926, he decided to write for a living. "Ce sera le début d'une vie agitée et le premier d'une série de départs" (Béguin 90).

His profession as a writer became the spiritual quest of his journey. Faithful to his interior calling to witness Christ, he pursued this quest in spite of the suffering which accompanied his choice. of his literary profession he wrote: "Le métier d'écrivain, n'est plus un métier, c'est une aventure et d'abord une aventure spirituelle. Toutes les aventures spirituelles sont des calvaires" (qtd. in Estève, Deuvres xlviii). More and more convinced of his vocation, he later wrote:

Le métier littéraire ne me tente pas, il m'est imposé. C'est le seul moyen qui m'est donné de m'exprimer, c'est-à-dire de vivre. Pour tous, une émancipation, une déliverance de l'homme intérieur, mais ici quelque chose de plus: la condition de ma vie morale. (qtd. in Estève, Deuvres $\mathrm{xlv}$ )

Within the first year after his decision to write, Bernanos experienced several significant life events: a new residence, a bout with depression, the death of his father, a pilgrimage to Lourdes due to his own recurring illness. In the summer of 1928 , he made a trip to the Shrine of Our Lady of La Salette as well as a pilgrimage 
to Ars, home of the modern day saint, John Vianney. This itinerant creator finished La Joie in Christmas week of that same year. Two years later, the deaths of his mother and a close clerical friend marked his personal journey. In addition, he suffered intermittently from "des crises d'angoisse."

In spite of these times of crisis, Bernanos was faithful to his calling to write. He continued to produce polemic essays, articles and work on other novels. However, the economic needs and maintenance of his family eventually distracted him from any concentrated writing efforts. In the midst of his attempts to earn a living by his pen, Bernanos' misfortune increased when he was involved in a serious motorcycle accident in July 1933. Needless to say, his material situation became worse during his months of convalescence. Permanently crippled and economically desperate, Bernanos moved his family once again.

This time he journeyed away from his beloved France to Majorque where he began what he described as "un beau vieux livre" (qtd. in Béguin 173). 11 This book, Journal d'un curé de campagne, is his masterpiece. Nearly a year later than he anticipated, Bernanos completed his story of a simple country priest. This creation was especially satisfying for him. The curé 
d'Ambricourt reflects its author intimately. Initially, Bernanos did not intend to publish the Journal. With affection, he confides:

Il m'est très pénible de parler de ce livre, parce que je l'aime. En l'écrivant j'ai rêvé plus d'une fois de le garder pour moi seul. . . Je l'aurais seulement glissé au fond d'un tiroir et il n'en serait sorti qu'après ma mort. Il eût réjoui mes amis. Je veux dire que nous nous serions réjouis ensemble -- eux dans ce mondeci, moi dans l'autre, et mon petit prêtre entre nous tous, à la limite du visible et de l'invisible -- ô cher confident de ma joie!. . . Hélas! on n'est pas plus mâtre de ses livres que de sa vie! (qtd. in Béguin 173) 12

This novel was published in March and surpassed the success of his first creation. For his favorite creation, Bernanos was awarded Le Grand Prix du Roman.

A fertile period of fiction writing at Majorque was interrupted by the Civil war in spain. The onset of this historical event reawakened the chivalrous spirit in Bernanos and inspired yet another polemic piece. He returned to France in 1937. Following a second motorcycle accident, however, he travelled to South America with his family. Although he initially moved his residence several 
times in Brazil, he eventually developed a small "French" farm known as la Croix-des-Ames. With the exception of an occasional trip to Rio and a summer island, Paqueta, Bernanos lived at this location for four years.

Assuming the role of warrior for a political cause once again, Bernanos campaigned passionately against the war through the press in Rio, the Bulletins de la France Libre, and La Marseillaise of London and Algeria. For the Dublin Review, he wrote Lettre aux Anglais which was subsequently published in Rio and disseminated secretly in Europe. Although exiled in Brazil, Bernanos became a great inspiration to the Resistance and represented his native country well to the world.

Summoned by General de Gaulle to France in 1945, this loyal soldier indefatigably continued his battle against what he perceived to be post-war deceptions of the Fourth Republic. Technology and totaliatarianism were decried in his innumerable articles in major publications throughout France. Exhausted from his efforts, Bernanos left France once again in 1947.

Tunisia was his destination this time. Living first at Hammamet and then at Gabès, he continued to write a series of articles and give lectures. What has been called his spiritual testament, Dialogues des Carmélites, was finished in mid-March 1948. Simultaneously with the 
completion of this work, he experienced a debilitating attack due to a liver disease. From this point on, Bernanos was bed-ridden. At this time, he vowed not to write anything else except a Life of Jesus which he had wanted to do for a long time. Shortly after the onset of this final illness, he was brought back to Paris for an emergency operation. He died at the American hospital in Neuilly on July 5, 1948. As a fitting close to the circuitous route of Bernanos' life, the body of this itinerant pilgrim and loyal warrior was laid to rest in the land of his childhood. His grave is found near his parents' tomb in the cemetery of Pellevoisin (Béguin 8994). 13

In the preceding discussion of formative elements in Bernanos' spirituality, characteristics of the medieval mindset were recaptured in the description of Bernanos' childhood experiences. His integration of the real and supernatural worlds is a major characteristic which permeated his life and writings. Observed within the context of his life, his spirituality, like a medieval one, is Christocentric. Fidelity to his vocation to witness to Christ is evidenced through his literary legacy. Obedient to his motivating force and ideal, the love of God, and to his Church, Bernanos was a faithful and loyal exemplar of his own times. Similar to his 
medieval parallels, he was a knight on a quest, a pilgrim whose way was not without suffering, an imitator of Jesus, and a loyal soldier whose life merited the honor he revered. 
NOTES

1 Georges Bernanos, Les Grands Cimetières sous la Lune (Paris: Plon, 1938).

2 -- , Nous autres Français (Paris: Gallimard 1939).

3 Zola, walter Scott, Hello, Bloy, Drumont, were among other authors read by the young Bernanos.

4 Bernanos, "To l'abbé Lagrange," mars 1905.

5 ---, "Lettre de la guerre à sa fiançée," 1917.

6 - - , "Lettre à sa fiancée."

7 ---, "Lettre à Dom Besse."

8 ---, "Lettre écrite en prison," Soyons libres,

avril 1909 .

9 ---, "Lettre à sa fiancée," 19 janvier 1916.

10 Bernanos, Les Grands Cimetières 114-15.

11 ---, "Letter from Palma," 6 janvier 1935.

12 -- , Le Cahier, novembre 1936.

13 See also Béguin, oeuvres romanesques $x \times x v-l i v$ and Louis Chaigne, Bernanos. 


\section{PART TWO: IMITATION AND PILGRIMAGE}

\section{THE BERNANOSIAN WAY AND MIRROR OF SELF-KNOWLEDGE}

CHAPTER III

CHILDHOOD: THE BEGINNING OF THE WAY

The meaning of childhood in the life and works of Bernanos is, paradoxically, both a point of departure and the final destination. "Mais l'enfant vers lequel Bernanos se retourne se définit justement par sa conscience de la mort. . ." (Picon, Deuvres, preface xxxii). A description of "la route" or the Way between these two points, childhood and death, can be likened to a reflection or the Mirror of the authentic self. The reflection of the latter becomes clearer as one moves forward in life. It is not unlike the mirror of St. Paul which is at first clouded, but gradually comes into focus. "Now we are seeing a dim reflection in a mirror: but then we shall be seeing face to face. The knowledge that I have now is imperfect; but then I shall know as fully as I am known" ( 1 Cor. 13:12). Both of these medieval images bear meaning in relation to the lived, exterior experiences of Bernanos as well as to his interior spiritual growth. The journey of this author, evident in the foregoing biographical presentation of Bernanos' life, is the setting for integration of the exterior and interior self. Simultaneously, the way becomes the Mirror 
wherein the reflection of self is the realization of one's own truth. As we recall from the account of Bernanos' childhood, the spiritual revelation at his first communion where he glimpsed his mortal destination, death, was a significant awakening. However, it was the adult Bernanos who retrospectively understood the more profound implication of this graced moment. The meaning of his childhood became synonymous with the realization that life could not be lived authentically without the acceptance of death as a part of life. For him, living this truth was only possible because of the Incarnation. Through this mystery, Bernanos' model of perfection, Jesus, took upon himself humanity and accepted death (Phil. 2:6-11). Car l'expérience de l'enfance est pour lui [Bernanos] celle d'une vérité qu'il a découverte seul. Dans la lettre à l'abbé Lagrange, il ne dit pas le réconfort d'une croyance transmise et partagée, mais le risque d'un audacieux affrontement. Il s'est révélé à l'enfant que la vie ne peut être vécue dans sa vérité que si nous acceptons de mourir, et que nous pouvons accepter de mourir parce que le Christ est mort pour nous, assumant notre humanité. (Picon, Deuvres $x x x i i i)$ 
To explore more deeply the richness of this revelation, its connection to the primary medieval images, and consequent Christocentric characteristics reminiscent of medieval spirituality, we turn to Bernanos' central Christ figures who reflect Jesus as the Way and image of perfection. To glean the richness of his own spirituality ever present in his writings, it is helpful to keep in mind that the voice of Bernanos is not only an echo of who he was for us, his readers, but more importantly, a reflection of who he was for himself. His childlike qualities, his weaknesses, his humanity, graced by continual conversion of self-giving, reflect the christ he recognized at the heart of his childhood.

Bernanos, lui, n'a jamais qu'une voix: la même dans les romans, les lettres, les notes du journal, la même dans les essais qui ne visent ni à démontrer $n i$ à convaincre, mais à toucher le coeur. Voix de l'aveu qui cherche le réconfort d'une amitié, voix d'une assurance avide de se répandre, voix de l'avertissement, de l'admonestation; coeur gros de l'enfant qui a besoin de partager le pain de solitude, âme du croyant, du militant, qui partage le pain de vérité: pour le meilleur et pour le pire, toute parole est une solidarité, toute parole veut 
donner quelque chose à quelqu'un. --Et, se parlant à lui-même, ce n'est pas dans l'identité qui fixerait et creuserait sa solitude, mais dans le dédoublement d'un dialogue où il est pour lui-même cet autre indispensable, l'ami tendrement rudoyé. . . (Picon, oeuvres xxviii)

Because the discussion in chapter one regarding the medieval imitation of Christ began with devotional practices pertaining to his infancy, this chapter addresses some principle Christocentric characteristics of Jesus' childhood which are found in the journeys of Donissan, Chantal, and the curé.

C'est que l'enfance, I'âge des départs, est aussi l'âge du risque assumé, et que tout naturellement elle se situe par là dans la perspective du salut, donc dans la droite ligne de l'imitation ou du refus d'imitation du Christ, dont l'étape parfaitement accomplie est toujours l'imitation du Christ crucifié. (Béguin $52)$

Adhering to the thematic images of the way and the Mirror, this discussion will reflect, through Bernanos' characters, the first step of his creative and real journey from cradle to cross. The infancy of Jesus was primarily characterized by qualities of poverty, humility 
and simplicity. These central virtues, as they reflect childlikeness will be addressed first. Affectivity expressed through tenderness, another virtue in the medieval edification theme, will be demonstrated in relation to maternal figures for the central characters as well as in relation to the three principal characters themselves: Donissan, Chantal and the curé. Lastly, the theme of chivalry will be discussed through the description of the "heroic child." The theme of the quest, war language and virtuous weaponry will be emphasized in this description.

Overall, this chapter, as well as the subsequent chapters contained in Part Two, provide a glimpse of Bernanos' contemplative response to salvation history in that the texts used echo his own personal imitation of Christ.

\section{CHILDLIKE POVERTY, HUMILITY AND SIMPLICITY}

Donissan: a poor and simple child

In the Middle Ages, the devotion to the nativity particularly inspired the faithful to contemplate and imitate the poverty, humility and simplicity of Jesus. The birth of Jesus was for Bernanos, a celebration of childhood primarily because it was the celebration of a special Child. Fittingly, Christmas enters into sous le 
soleil de satan in a significant way. It is Christmas Eve when the abbé Menou-Segrais bares his scrupulous soul about the "jeune prêtre" in his parish to his old friend and confessor, the abbé Demange. The mention of "Noël" in the first part of the novel occurs twice. These texts provide a framework for the key introduction of the main figure, Donissan. The first reference is an expression of disappointment by Menou-Segrais. "Je suis désolé que vous ne puissiez passer avec moi cette nuit de Noël. . ." (SS 122). The second mention of Christmas is linked with childhood through specific reference to "The child." Consistent with Bernanos' understanding of childhood juxtaposed with the realization of death, it is no surprise that the mention of the latter is paradoxically present in this brief text. This time it is Demange who laments :

Je suis fâché de vous quitter si tôt. . . oui, j'aurais aimé, j'aurais particulièrement aimé passer cette nuit de Noël avec vous. Cependant, je vous laisse à plus puissant et plus clairvoyant que moi, mon ami. La mort n'a pas grand-chose à apprendre aux vieilles gens, mais un enfant, dans son berceau! Et quel Enfant! . Tout à l'heure, le monde commence. (SS 125) 
Prior to and between these two texts, precursory language referring to a "child" is used. Expressions such as "jeune," "petit sauvage," "pauvre," "simple" in reference to Donissan, prepare Bernanos' reader for the appearance of this main childlike character. The description of the sudden presence of this young priest before the two older clerics captures characteristics of a child including allusions to smallness, single-mindedness, clumsiness, disorderliness, confusion and dismay.

Au seuil du vestibule obscur, sa silhouette, prolongée par son ombre, parut d'abord immense, puis, brusquement--la porte lumineuse refermée-petite, presque chétive. Ses gros souliers ferrés, essuyés en hâte, étaient encore blancs de mortier, ses bas et sa soutane criblés d'éclaboussures et ses larges mains, passées à demi dans sa ceinture, avaient aussi la couleur de la terre. . Le désordre, ou plutôt l'aspect presque sordide de ses vêtements journaliers, était rendu plus remarquable encore par la singulière opposition d'une douillette neuve, raide d'apprêt, qu'il avait glissée avec tant d'émotion qu'une des manches se retroussait risiblement sur un poignet noueux comme un cep. (SS 124-25) 
In this text, Donissan's poverty is reflected in his exterior appearance. His shoes and clothing still bear evidence of the physical labor in which he was engaged prior to being summoned by his superior. This reference to the "ordinariness" of a Donissan who, not unlike a carpenter's Son, engages wholeheartedly in the menial tasks of common folk also points to a spirit of humility and simplicity. Later in the novel, Donissan's inclination to perform manual labor is critiqued cruelly by his superior, Menou-Segrais, as a sign of an inferior vocation. These dutifully candid, but stinging words to the "grand enfant" conclude with a brutal suggestion that Donissan return to his labor in the fields. The word used, "charrue," alludes to the inferiority of the menial task as it presents other lowly images such as sweat and dirt. These are integral to working the earth.

La force qui vous a été départie, votre addrese même à certains travaux manuels, c'était là sans doute le signe d'une vocation moins haute, où la Providence vous appelait. . Est-il jamais trop tard pour reconnâ̂tre, guidé par de sûrs avis, une erreur involontaire? . . Devrezvous tenter une nouvelle expérience. . ou bien. . ou bien. . --ou bien? . . osa demander l'abbé Donissan. 
--ou bien retourner à votre charrue? conclut le doyen d'un ton sec... (SS 128)

In addition to the ordinariness in the initial description of Donissan, the visible attempts to put some order into his dishevelled appearance, accompanied by a shy transparence, likewise reflect a childlike simplicity. The image of the earth (also present indirectly in the aforementioned term, "plow") colors this character with a humble quality. The earth is intricately associated with the image of dust. Combined with the image of light present in the first descriptive text through the word "resplendir," and Donissan's overall confusion, the earth image reinforces an immediate mystical dimension in the description of this character.

Dust is also used in descriptive passages to create an aura of confusion or mysticism, and appears in this sense often in sous le soleil de Satan. (Morris 80)

This mystical quality, along with the images of poverty, humility and simplicity in the text point to the appearance of another Child. It is the Infant Jesus who is named subsequent to Donissan's exit from the room. Hence, this introductory description is intricately connected with Christmas, the day which Bernanos described as "the celebration of childhood" (qtd. in Béguin 98).1 
This specific celebration, childhood, is characterized as an initial time of peace and hope as is Christmas. It is towards childhood that other bernanosian characters turn for consolation along their respective journeys of imitation.

Chantal: a mystical child

A mention of Christmas is present in La Joie only as a retrospective yearning for the calm and carefree experience of childhood reminiscent of Bernanos' own early years. An innocent Chantal humbly longs for a simple life free from notice and acclaim by others.

Oui, j'eusse désiré une vie sans histoire, la plus claire possible, et d'être à la fin une petite vieille, aux joues roses, qui rit toute seule dès le matin, rose comme une praline, et meurt aussi tranquillement qu'elle mettait jadis ses souliers dans la cheminée, la nuit de Noël. ( $\mathrm{J}$ 669-70)

Although a Divine Child is not specifically alluded to in this text, a "child" who possesses supernatural qualities is present from the outset of the novel. Ironically, the first glimpse of a holy and pure chantal is through the voice of the most vile character of the story, M. Fiodor, "le Russe." He describes her simply as "un enfant. . . 
un vrai petit ange, aussi léger qu'une fleur de chardon" ( J 543-44). The imagery of a heavenly creature juxtaposed with a thorny weed carries much richness. The air symbology elicited by both the angel and the lightness of the thistle contrasts with the earth image of the lowly weed. Through these images, the "child" becomes an incarnational prototype from the outset. Physical characteristics of the littleness of a child are scattered throughout: "Sa petite main toujours calme" ( $J$ 546) "un geste enfantin" ( J 548), "son pas juste et léger" ( J 552), "le regard d'un enfant" ( $\mathrm{J}$ 600), "la chère petite" ( 632), "la petite main grande ouverte" ( J 676) "la mince petite figure" ( $\mathrm{J}$ 703). These descriptions serve as external reminders of Chantal's interior childlike qualities which are principally those of poverty, humility and simplicity.

Childhood and Chantal's poverty are intricately linked in this novel. Bernanos aligns his heroine with a saint who particularly inspired him, Thérèse of the Child Jesus, revered for her "little way" of perfection. It is significant that this child model of perfection who bears the name of the christ child is textually connected with Chantal. Awaiting God's action in the consoling transports of her contemplative prayer, Chantal experiences "les heures de jadis, si pareilles à celles de 
l'enfance" where, like Thérèse, she exclaims joyously: "Je ne puis tomber qu'en Dieu." Likewise, using the words of this child saint, also known as "The Little Flower," Bernanos likens Chantal to "un petit grain de poussière impalpable, suspendue dans la volonté de Dieu" (J 552, 604). The falling image, which is a "fall into a spiritual abyss" or an ascending fall, as well as the grain of dust image, represent a childlike, transparent openness which is a prerequisite to submission (Morris 6869). Once again, as in the initial presentation of the Christ figure, Donissan, a mystical quality is present. Chantal's mystical prayer, "ce sommeil heureux du désir, n'était rien d'autre que la miraculeuse insouciance des enfants, leur pureté" ( J 552). This desire for God was her singular joy. This joy was her all which she commended to her dying friend and spiritual father, Chevance. Bernanos describes her gift as "son indicible pauvreté" and queries, "Qui peut s'émouvoir d'être pauvre entre les mains d'un seigneur plus riche que tous les rois?" He continues to describe the poverty of this child as an interior search for spiritual frailty. But Chantal viewed her own littleness or weakness as a verification of God's presence within her. Her poverty was a fundamental, supernatural poverty which "avait brillé sur son enfance, 
ainsi qu'un petit astre familier, une lueur égale et douce" ( $J$ 553).

Similar to Donissan, Chantal's desire for the ordinary characterizes her simplicity. Several examples demonstrate Bernanos' careful creation of a child saint who participates in the daily routine and insignificant aspects of the human condition as did Jesus.

Elle croyait sa vie trop simple, trop étroitement commandée par des devoirs monotones, quotidiens, pour qu'elle risquât de s'éloigner jamais beaucoup, moins par vertu que par une humble nécessité, de la place exacte où l'eût cherchée le maître le plus exigeant. ( $J$ 558) In spite of a transformation in her prayer which lifted her into mystical realities not fully understood by her, Chantal did not exempt herself from her routine duties and responsibilities:

La méprise fut d'autant plus facile qu'elle avait continué à s'acquitter de ses devoirs et à gouverner sa maison avec la même allégresse qui ressemblait si fort à celle des enfants . . . ( $564)$

Similarly, temptations to scruples in her sensitive soul were conquered by her simple faithfulness to the daily 
tasks common to all. The ordinary became a place of refuge for her.

- . elle ne souhaitait que reprendre sa tâche quotidienne, l'exercice des devoirs simples, définis, authentiques, rentrer dans la vie mortifiée, asile universel, lieu unique, ouvert aux saints et aux pécheurs, où elle sentait le repos, ainsi qu'une brebis perdue sous l'orage. - ( ( 574 )

Still another example of Chantal's adherence to the ordinary occurs in a scene with her father. M. de Clergerie is futilely attempting to convince Chantal to enter religious life because of her spiritual gifts of simplicity, innocence, and her spirit of childlike submission ( $J$ 588). But his daughter reacts firmly:

$\mathrm{Ni}$ vous, ni le doyen d'Idouville, ni personne au monde, et pas même un ange, ne me convaincraient d'entrer en religion une heure trop tôt. Que j'accomplisse de mon mieux les petits devoirs, au jour le jour--hélas selon mon humeur et mes forces... ( J 590)

The curé: an ordinary child

The poverty, humility, and simplicity of the crib are present from the beginning of Journal d'un Curé de 
Campagne. Although Christmas is not specifically mentioned, Bernanos prepares the way for the textual introduction of the Infant Jesus. The "petit écolier" at the outset of his diary, his "cahier d'écolier" (JCC 1032), describes the coughing of animals who find shelter in "l'étable chaude, odorante" (JCC 1031). This humble image of beasts of burden is a precursor to a nativity motif. This latter comes to light through the curé d'Ambricourt's account of an impressionable visit with his jovial friend and confidant, the curé de Torcy. This commonsensical cleric is a model of edification for his young friend, whom he affectionately addresses as "mon petit enfant." In this description, the cure de Torcy leads the naive priest through a magnificent bedroom into an adjacent starkly furnished room. The characteristics of the room, crowned by a "vilain" chromo on the wall of "un Enfant Jésus bien joufflu, bien rose, entre l'âne et le boeuf," reflect a stark simplicity befitting its function as a prayer room. Recalling this visit, the curé describes its contents. "Il m'a conduit dans une autre pièce très nue, meublée seulement d'une table et d'un prie-Dieu" (JCC 1041). The picture itself, a gift from the curé de Torcy's godmother, is described by him as ugly, inexpensive and "un peu bête." But in spite of its affront to quality or any resemblance to the artistic, it 
is preferred by this down to earth priest as a reminder of his call to ordinary service in spite of his wealthy heritage.

Mon Enfant Jésus est trop jeune pour s'intéresser encore beaucoup à la musique ou à la littérature. Et même il ferait probablement la grimace aux gens qui se contenteraient de tortiller de la prunelle au lieu d'apporter de la paille frâ̂che à son boeuf ou d'étriller l'âne. ( JCC 1043)

The significance of bringing nourishment to the beasts is synonymous with the curé de Torcy's priestly vocation of ministering to his parishioners. His analogical term for those he serves is "un troupeau." This herd does not comprise beasts of the finest quality, but the simple, poor, ordinary beasts who work the land. Contrary to considering himself apart from those he has the responsibility to serve, the curé de Torcy aligns himself with this motley mass.

--du simple bétail--; à quoi je ressemblerais, veux-tu me dire? Du bétail, ni trop bon ni trop mauvais, des boeufs, des ânes, des animaux de trait et de labour. Et j'ai des boucs aussi.. - nous devons nous arranger de tout, même des 
boucs. Boucs ou brebis, le maitre veut que nous lui rendions chaque bête en bon état. (JCC 1044) This nativity scene made of stone is for this wise cleric then, a reminder of the real pain and frailty of the human race, but also becomes a call to imitation of a child whose role was primarily incarnational, that is, assuming the form of those he came to serve (Morris 23).2

While engaged in the simple, ordinary task of peeling potatoes, the cure d'Ambricourt reveals his own simplicity and poverty of spirit as he ponders his friend's wise words during their previous encounter.

Apporter de la paille fraîche au boeuf, étriller l'âne: ces paroles me scnt revenues ce matin à I'esprit tandis que je pelais mes pommes de terre pour la soupe. (JCC 1047)

The image of feeding the humble beasts of the stable serves as a refrain which continues the Christmas motif and its rich connotations of an incarnational Infant who has come to serve. In its second repetition, the curé mirrors this Infant as the image takes on a broader meaning, namely, the task of caring for his own parishioners. His poverty of spirit and simplicity are evident as this "fils du paysans" writes honestly about the complexity of a seemingly simple task. 
Apporter de la paille fraîche au boeuf, étriller I'âne. - . soit. Mais les besognes simples ne sont pas les plus faciles, au contraire. Les bêtes n'ont que peu de besoins, toujours les mêmes, tandis que les hommes! Je sais bien qu'on parle volontiers de la simplicité des campagnards. Moi qui suis fils de paysans, je les crois plutôt horriblement compliqués. (JCC 1047)

Similar to Donissan and Chantal, there are innumerable descriptions which point to a poor, humble and simple curé which are not directly associated with Christmas in the text, but which continue to reflect principle interior and exterior qualities of the Child. The diary form of the novel itself acts as an autobiographical testimony to the childlikeness of the curé inasmuch as it is a record of the ordinary steps in his journey to holiness. A humble tone characterizes his motives for writing.

Je ne crois rien faire de mal en notant ici, au jour le jour, avec une franchise absolue, les très humbles, les insignifiants secrets d'une vie d'ailleurs sans mystère. Ce que je vais fixer sur le papier n'apprendrait pas grandchose au seul ami avec lequel il m'arrive encore 
de parler à coeur ouvert et pour le reste je sens bien que je n'oserai jamais écrire ce que je confie au bon Dieu presque chaque matin sans honte. (JCC 1036)

His diary does not glorify virtue or hide weakness, but with the candor and confidence of a child, this fledgling priest writes what is true. From the outset, the reader glimpses an almost transparent central character. Frailness of body, dryness of spirit, hope in the Incarnation all color Bernanos' very ordinary country priest. In the lamplight, the young priest pens his initial idea of the purpose for his diary.

Dans mon idée, il devait être une conversation entre le bon Dieu et moi, un prolongement de la prière, une façon de tourner les difficultés de l'oraison, qui me paraissent encore trop souvent insurmontables, en raison peut-être de mes douloureuses crampes d'estomac. Et voilà qu'il me découvre la place énorme, démesurée, que tiennent dans ma pauvre vie ces mille petits soucis quotidiens dont il m'arrivait parfois de me croire délivré. J'entends bien que NotreSeigneur prend sa part de nos peines, même futiles, et qu'il ne méprise rien. (JCC 1048) 
The journal is explicitly identified as a mirror image which reflects a mysterious presence. As the young priest writes, he is overcome with a desire to cry. Tears in Bernanos' novels are often used in reference to positive values such as God's love, a childlike nature, humility and innocence (Morris 157-58). 3 His awareness of and tearful response to such a presence provide early hints of a spiritual childhood closely linked with mystical qualities (Morris 159).4

Tandis que je griffonne sous la lampe ces pages que personne ne lira jamais, j'ai le sentiment d'une présence invisible qui n'est sûrement pas celle de Dieu--plutôt d'un ami fait à mon image, bien que distinct de moi, d'une autre essence. • - Hier soir, cette présence m'est devenue tout à coup si sensible que je me suis surpris à pencher la tête vers je ne sais quel auditeur imaginaire, avec une soudaine envie de pleurer qui m'a fait honte. (JCC 1049)

Similar to Donissan, the curé's exterior appearance carries with it the traits of a child. A poor and simple impression is sometimes combined with awkwardness, confusion and dismay. On one occasion when the curé was invited to "le château," he planned to wear a cassock which he reserved for exceptional circumstances. However, 
due to a loss of weight caused by a cancer, his special attire was much too large. Consequently, he had to wear his daily cassock. He was confounded by this simple upset as he felt the well-worn condition of his daily clothing would cause him to flaunt poverty.

$$
\begin{aligned}
& \text { Il m'en coûte un peu d'aller au château avec } \\
& \text { celle que je porte d'habitude et qui a été } \\
& \text { maintes fois reprisée, surtout au coude. Je } \\
& \text { crains d'avoir l'air d'afficher ma pauvreté. } \\
& \text { Que ne pourrait-on croire! (JCC 1058-59) }
\end{aligned}
$$

Conversely, a similar discomfort with a display of luxury motivates the simple priest to counteract any interieur complacence which might lure him away from true poverty of spirit. He writes:

J'habite un presbytère très confortable, la plus belle maison du pays, après le château, et je laverais moi-même mon linge! J'aurais l'air de le faire exprès. (JCC 1050)

In addition to washing his own linen, the curé is not adverse to preparing his own soup. We have already glimpsed him peeling potatoes. In a straightforward way, like a child laughing at his own awkward antic, this simple priest describes how he rose to greet the assistant commissioner with potato peelings still in his lap. 
L'adjoint est arrivé derrière mon dos et je me suis levé brusquement de ma chaise sans avoir eu le temps de secouer les épluchures; je me sentais ridicule. (JCC 1047)

Instances of feeling awkward and inept also appear in a penned honesty about his lack of management skills in relation to his "petite paroisse." He traces his seeming ineptitude to an ancestral background of poverty.

Mais je descends d'une lignée de très pauvres gens, tâcherons, manoeuvres, filles de ferme, le sens de la propriété nous manque, nous l'avons sûrement perdu au cours des siècles. Sur ce point mon père ressemblait à mon grand-père qui ressemblait lui-même à son père mort de faim pendant le terrible hiver de 1854. . . maman avait beau mettre son meilleur jupon, sa plus belle coiffe, elle avait cet air humble, furtif, ce pauvre sourire des misérables qui élèvent les enfants des autres. (JCC 1056)

This bewildered, yet candid sense of inadequacy continues to appear in other reflections.

Je suis chaque jour plus frappé de mon ignorance des détails les plus élémentaires de la vie pratique, que tout le monde semble connaître 
sans les avoir appris, par une espèce d'intuition. (JCC 1055)

The curé's journal entries change from a bewildered tone to one of smallness and confusion. Following a monthly meeting with his fellow priests from the region, he recalls sadly coming home "sous la pluie" (JCC 1055). The image of rain and his unique feelings of littleness in the midst of a prestigious clerical crowd, convey a feeling of loneliness and solitude (Morris 173).

Au cours de la discussion sur les caisses rurales, j'avais l'impression d'être un enfant fourvoyé dans une conversation de grandes personnes. (JCC 1055)

As a solitary child then, this simple priest already reflects the solitude of the cross and death, which for Bernanos were unified in a retrospective, lucid revelation in his own spiritual journey.

\section{MATERNAL TENDERNESS}

Another characteristic of the medieval period reflected in devotions related to the Infancy of Jesus was that of tenderness. This quality was associated with both the Infant himself as well as with the surrounding figures of the nativity. In particular, the role of the virgin Mary elicited imitation of maternal tenderness. This 
trait is first seen in three secondary characters who act as immediate models for Donissan, Chantal and the curé. Similar to the medieval canon whose role of imitation included an affective response towards those he served, Menou-Segrais, Chevance and the curé de Torcy respond tenderly to their childlike companions. They become secondary Christ-figures who exemplify "Jesus as Mother" (Bynum, Jesus $129 \mathrm{ff}$ ). 5

\section{The tenderness of Menou-Segrais}

In Sous le soleil de Satan, a first indication of such tenderness follows Donissan's episode of imprudent fervor with the discipline. Reflecting the tender gestures of a Virgin Mother at the crib where she wraps her Child in swaddling clothes and in the aftermath of the crucifixion where she holds Jesus in her arms, MenouSegrais gently unloosens the bloodied clothing of Donissan. The latter, dismayed at his superior's discovery of his secret, buries his head in his hands. Reassuringly, Menou-Segrais "les écartaient doucement, découvrant la rude tête, d'un geste presque maternel" (SS 132). Trying to disguise "sa tendresse" the older priest assists Donissan into his own armchair and - parlant toujours, glissait un oreiller sous la tête douloureuse. Puis, s'asseyant sur 
une chaise basse, et ramenant frileusement autour de lui sa couverture de laine, il se recueillait une minute, le regard fixé sur le foyer, dont on voyait danser la flamme dans ses yeux clairs et hardis. (SS 132)

This tender scene ends with the sound of the Angelus, the prayer announcing the maternity of Mary and the mystery of the Incarnation. It is dawn, the bernanosian moment of childhood, and the room is symbolically filled with gentleness, warmth and a mystical aura through reference to the burning logs crumbling into ashes.

Les trois premiers coups de l'Angélus de l'aube tintèrent au-dehors comme un avertissement solennel, mais ils ne l'entendirent pas. Les bûches croulaient doucement dans les cendres. (SS 133)

\section{The tenderness of Chevance}

Although already dead, Chevance continues to be the beloved spiritual parent for Chantal. In a moment of scrupulous self-scrutiny, Chantal imitates the consoling voice of this maternal guide who, even in death, continues to nourish her spirit.

Elle continuait à se parler à elle-même, tout bas, presque tendrement, comme on rassure un 
enfant ou un fou. Etait-elle alors sincère, absolument? Condamnait-elle avec tant de dureté, rejetait-elle sans remords, une fois pour toutes, ce qui--elle le sentait bien à présent-avait été depuis tant de semaines sa nourriture mystérieuse? . . 'Méfiez-vous de ce qui trouble!' I'ordre si souvent répété de son vieil ami l'abbé Chevance retentissait encore dans son coeur. ( J 573)

A similar, reminiscent, maternal image of tenderness appears when Chantal is attempting to discern the mystical movement of her prayer. Once again, it is to the memory of Chevance that she turns.

Certes, l'image de Chevance, son nom même, semblait bien loin de sa pensée. . Pourtant, par un prodige unique, d'un mouvement de l'âme aussi pur, aussi innocent qu'aucun de ces gestes inhabiles qui ravissent d'amour et de pitié le coeur des mères, elle craignit vaguement d'avoir désobéi; elle se retourna vers son vieux maître, ainsi que gémit, en dormant, un nouveau-né. Qu'eût-il pensé? Ne l'eût-il pas arrêtée depuis longtemps, d'un de ces sourires anxieux qu'il avait, si tristes, si tendres? Aurait-il permis qu'elle le précédât sur de tels chemins? ( J 683) 
The tenderness of the curé de Torcy

The maternal characteristics of the curé de Torcy are not predictable from the initial introduction to this practical and likable character in the Journal. A first impression of his jovial, warm-hearted and down-to-earth personality is sketched with descriptive phrases such as "gros rire bonhomme," "rondeur bourrue," and "commun" (JCC $1040,1072)$. As a child admires a superhero, the curé d'Ambricourt enthusiastically describes his experienced friend's qualities. "Mon Dieu, que je souhaiterais d'avoir sa santé, son courage, son équilibre" (JCC 1036). The young priest's admiration for his friend does not veil his ability to see beyond the surface. He writes:

Il m'observait de biais sans en avoir l'air et, dans ces moments-là, je crois voir au fond de son regard beaucoup de tendresse--comment dirais-je?--une espèce d'inquiétude, d'anxiété. ( JCC 1040)

In surprised simplicity, the curé recalls other gestures which betray the curé de Torcy's maternal solicitude towards his "petit enfant." In a first example, he physically provides reassurance through the gift of touch. "J'ai tout à coup senti ses deux mains sur mon épaule" (JCC 1076). Following this unanticipated action, another gratuitous gesture wraps this "barefoot altar boy" with a 
sense of security which insulates him momentarily from the fear of death (JCC 1077).6
Alors, il s'est passé une chose très surprenante. Il a poussé une chaise tout contre moi, il s'est assis, m'a pris les mains dans les siennes sans quitter mon regard du sien, ses yeux magnifiques pleins de larmes, et pourtant plus impérieux que jamais, des yeux qui rendraient la mort toute facile, toute simple. ( JCC 1077)

Terminology of maternal tenderness is also used by the curé de Torcy himself. Similar to the medieval canon who exemplified Jesus for those in his community, this seasoned cleric surprises his simple companion with a sudden gentle tone of voice in a sermonic monologue about the Word of God. He says, "Notre-Seigneur parle tendrement à ses pauvres. . ." (JCC 1078). He proclaims that no one can be insensitive "à la douceur, à la tendresse de la parole. . ." (JCC 1072). In this monologue, an incarnational word is presented as a Child who comes for children. The curé de Torcy's tender tone carries the image of an innocent newborn whose initial moments of carefree beatitude are aligned with the sweetness of death. ${ }^{7}$ The familiar bernanosian theme stemming from the author's first communion grace comes to 
Iife in this text. The image, like a journey, links birth and death in the hopefulness of a Promised Child whose kingdom is only for the childlike.

Et puis la nature agit de même: est-ce que pour le petit enfant qui repose dans son berceau et qui prend possession du monde avec son regard éclos de l'avant-veille, la vie n'est pas toute suavité, toute caresse? Elle est pourtant dure, la vie! Remarque d'ailleurs qu'à prendre les choses par le bon bout, son accueil n'est pas si trompeur qu'il en a l'air, parce que la mort ne demande qu'à tenir la promesse faite au matin des jours, le sourire de la mort, pour être plus grave, n'est pas moins doux et suave que l'autre. Bref, la parole se fait petite avec les petits. . 'si vous n'êtes pas comme l'un de ces petits, vous n'entrerez pas dans le royaume de Dieu.' (JCC 1072-73)

\section{Mirrors of tenderness}

The maternal tenderness exemplified by each of the spiritual parents is inevitably and necessarily present in the three main characters. Inasmuch as Donissan, Chantal and the curé d'Ambricourt mirror the Infant, who is simultaneously the recipient of Mary's tenderness and the 
maternal Jesus, these Christ figures clearly demonstrate their model's maternal quality.

In a textual comparison with a mother's impatience to caress her child, Donissan is portrayed as a pilgrim on a mission. He hastens his steps toward his destination, the old village church of Etaples. In his imagination, he sees the human crowd of "petit peuple féminin" gathered near the confessional. They are "habile à gagner la première place, querelleur, à mines dévotes, regards à double et triple détente, lèvres saintement jointes ou pincées d'un plis mauvais." Near them, the men, the "troupeau murmurant, si gauches et si roides!. . ." also await him (SS 156). Bernanos describes Donissan's maternal reaction as the sight of the church inspires him to envision these simple souls entrusted to his care.

Le rude jeune prêtre. . s'émeut d'une tendresse inquiète; il hâte le pas sans y songer, avec un sourire si doux et si triste qu'un roulier qui passe lui tire son chapeau sans savoir pourquoi. . On l'attend. (SS 156)

This caregiver of souls is again compared to a mother's solicitous sensitivity to her child when Donissan meets the troubled adolescent, Mouchette, on the roadside. He experiences a deep pity for her. ". . une violente pitié était déjà dans son coeur. N'est-ce point ainsi 
qu'une mère s'éveille en sursaut, sachant de toute certitude que son enfant est en péril?" (SS 198)

The maternal tenderness of Chantal is more symbolic in La Joie. As we have seen, this character acts as the foreground representation of the saintly maternal model, Chevance, in a type of "mise en abîme" which originates with the spirituality of Bernanos himself. Nearly all the characters who surround this child are confronted with their own truth. Chantal provides them with spiritual nourishment which they are free to accept or reject. As a mother labors to bring her children into the light from the darkness of the womb, Chantal's presence illumines the sinfulness around her. ${ }^{8}$ what she recognizes is nearly overwhelming. At one point, "la jeune fille intrépide et sage, si tendre à tous, eut cette folle pensée de fuir. . ." (J 605). Instead, she literally and figuratively, bears the painful burden of others. Love motivates her. In one instance, her father, who wallows in rationalization and self-loathing is caressed by her declaration, "Oh! papa, je vous aime!" ( $J$ 593) As her transparent sensibility is nearly overwhelmed by the heaviness of sin, Bernanos gives us a glimpse of the compassionate maternal quality in this child saint. Car elle venait d'étouffer, par un effort immense, la révolte de son coeur. Les faibles 
mains frémissantes faisaient, à son insu, le geste d'effacer, de couvrir, et son regard resplendissait de cette sorte de pitié qu'on ne voit qu'aux yeux des mères. ( J 593)

In the curé d'Ambricourt, a similar quality of tenderness is present. Although not textually described as "maternal," it can be identified by a patient and gentle frankness towards the obstinate individuals whom his presence confronts. Like Donissan, the curé is on a mission to care for souls. Far from a conscious, zealous call to attack wickedness with brute force, his vocation exacts a day to day journey through the ordinariness of "petites choses" and a triumph of "petites joies" so wellreflected throughout his diary (JCC 1255). One by one the "children" of his parish cross his path. He guides the hate-filled adolescent, Mlle Chantal, towards the confessional, and later, towards the door of the church "doucement" (JCC 1133, 1136). In his compassion, he addresses Mme la Comtesse spontaneously as "ma fille" (JCC 1161).9 And similar to the mystical Chantal of La Joie, his own childlike comportment and candor elicit confessions of deeply buried secrets from the solitude of sinfulness. Mme la Comtesse exclaims:

- . il me semble qu'un autre enfant m'a tirée de cette solitude. J'espère ne pas vous 


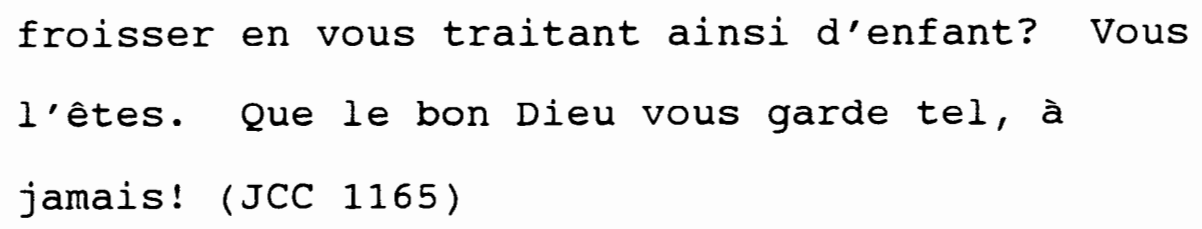

THE CHIVALROUS CHILD

At this point, the discussion moves from the foregoing sampling of similarities between medieval characteristics of maternal tenderness and bernanosian characters to likenesses with another major medieval theme, namely, chivalry. Elements of chivalry, particularly the virtuous aspects, infiltrated expressions of medieval devotion including the imitation of the Christ Child. Jesus' mother likewise became an important exemplar of innocence and purity, and indeed, was often the ideal woman and inspiration for a knight's quest. Medieval Christocentric characteristics are identified once again in Donissan, Chantal and the curé as we focus on their common role as a chivalrous child.

\section{Quest, virtue and battle}

Reminiscent of the humble, yet heroic Christ child who comes to save, to conquer sin and death, the three central "children" of Bernanos" novels are quickly engaged in a salvific purpose as they enter into the redemptive journey of Jesus. Theirs is a crusade for souls which 
bears the marks of the medieval, penitent pilgrimage as well as of the chivalrous, mystical quest. The way of their mission is presented on the bernanosian double plane of the real and the spiritual. Their "road" incorporates an exterior landscape which mirrors a rich interior view of personal struggle and spiritual adventure. The knightly honor, bravory and valor of all three childlike characters flow from their single-hearted devotion to the Love of their life. The inspiration of an All-loving God provides them with the spiritual strength to do battle against the wickedness which surrounds them. In spite of their physical littleness and frailness, they are each armed with purity of heart. This quality is identical with the ever-present Christ-like poverty of spirit and simplicity which shield them from pride and protect their innocence.

Donissan's mission is "pour les seuls pécheurs" (SS 189). Through the voice of his spiritual confessor, Menou-Segrais, this simple and obedient penitent is commissioned to pursue his vocation, his quest. The fatherly cleric recognizes Donissan's virtuous readiness for such a perillous adventure. 10 Alone, he must embark on the march towards sanctity which is not devoid of suffering. The implications of this passage point to another child whose mystical quest for souls necessitated 
the ultimate unselfish spirit, the sacrifice of self as victim.

Là ou Dieu vous attend, il vous faudra monter, monter ou vous perdre. N'attendez aucun secours humain. Dans la pleine conscience de la responsabilité que j'assume, après avoir éprouvé une dernière fois votre obéissance et votre simplicité, j'ai cru bien faire en vous parlant ainsi. En doutant, non pas seulement de vos forces, mais des desseins de Dieu sur vous, vous vous engagiez dans une impasse: à mes risques et périls, je vous remets dans votre route; je vous donne à ceux qui vous attendent, aux âmes, dont vous serez la proie. . Que le seigneur vous bénisse, mon petit enfant! (SS 134)

In response to Menou-Segrais' words, Donissan reacts "comme un soldat qui se sent touché" (SS 134). Here, Bernanos descriptively combines a human characteristic so present in his own childhood with a paradoxical mystical allusion. His soldier is characterized with these words: ". . cette âme, encore soulevée de terreur, rendait sublime" (SS 134).

Following his commissioning by Menou-Segrais, Donissan recognizes the "champ libre" where he is determined to overcome every obstacle to his exterior 
ministry to others (SS 135). Humiliating challenges such as "la quête de carême" imposed upon him by his superior, reflect only minimally his continual interior struggle (SS 137, 153). The inner recesses of his own battle are echoed by expressions throughout the novel such as "lutter contre soi-même," "se surmonter," "il conquiert," "il se débattait en aveugle." war words such as "le combat," "son ennemi," "l'adversaire," only hint at the role of this child crusader against the Prince of Darkness. Rather than glorifying his main character as "l'un de ces saints dont l'histoire ressemble à un conte, de ces doux qui possèdent la terre, avec un sourire d'enfant-roi. . ." (SS 147), Bernanos creates a fearful child transformed into a warrior whose hate is aptly vengeful. The same text includes a blood image which signals not only the exterior thematic of war, but points to spiritual suffering linked with the blood of a crucified Savior. "Il est né pour la guerre; chaque détour de sa route sera marqué d'un flot de sang" (SS 147).

It is the love of God, demonstrated by the salvific gift of his only Son, which continually motivates Donissan to accept the challenge to defy evil. Indeed, he is "cette âme forcenée" who prays his "Suscipiat" before the cross (SS 154-44). Purity of heart strengthens him for combat. "Et il défiait l'abîme, il l'appelait d'un voeu 
solennel, avec un coeur pur. . " (SS 155). A child's simplicity equips him with the necessary weaponry. "Dieu soit béni, mon enfant, parce que vous avez si franchement et si humblement parlé. Car cette simplicité désarme l'esprit du mal même" (SS 219).

Chantal's crusade for souls, unlike Donissan's, was not a conscious deliberate mission. Naive and innocent, this "enfant héroiqque" is unaware of her call at first. Through the observations of secondary characters, Chantal is portrayed as "un enfant" who epitomizes all that hate and sin are not. In contrast to the heaviness and downward pull of fear suggested by a world of lies, she is "cette petite, l'éther" who embodies all that is light, airy and refreshing ( $J$ 543). M. Fiodor, a dark character of the novel, is the one who reveals her salvific role. La Mademoiselle est trop pure, elle va, elle vient, elle respire et vit avec la lumière, hors de nous, hors de notre présence. Et néanmoins elle rayonne à son insu, elle tire de l'ombre nos âmes noires, et les vieux cruels péchés commencent à s'agiter, bâiller, s'étirent, montrent leurs griffes jaunes - . Demain, après-demain--qui sait?--une nuit, cette nuit même, ils s'éveilleront tout à fait. (J 626) 
Unaware even of "sa propre aventure, ayant trop vécu au jour le jour, heure par heure," Chantal is gradually awakened to her mystical role ( $\mathrm{J}$ 691). Her vocation, first recognized in "l'appel muet" of her deceased spiritual father, is primarily to love ( $\mathrm{J} 558$ ). Chantal recalls Chevance's words about the grace of a jealous God which is a gift "de nous aimer ainsi que nous aimons les petits" ( $\mathrm{J}$ 558).

War language also figures in the story of the chivalrous Chantal. As her very presence confronts the lying and mediocre characters around her, battle language abounds. There are expressions denoting struggle, obstacles, challenges, regrouping forces, defending oneself, fighting with oneself, feeling disarmed as well as the "grands débats de I'âme" ( $\mathrm{J}$ 611).11 Chantal's weaponry is similar to that of Donissan. The simplicity of the truth is her strongest sword and her armor is purity of heart. An exquisite description of her battle tactics occurs in the scene with her grandmother, Mme de Clergerie, who has just revealed her long-concealed secret of hatred for Chantal's mother. Typical of a child, Chantal imitates her spiritual parent, Chevance. L'unique ruse de Chantal est justement celle d'un Chevance: une foudroyante simplicité. Alors que le faible ou l'imposteur est toujours 
plus compliqué que le problème qu'il veut résoudre, et, croyant encercler l'adversaire, rôle interminablement autour de sa propre personne, la volonté héroïque se jette au coeur du péril et l'utilise, comme on retourne l'artillerie conquise pour frapper dans le dos une troupe vaincue. Elle s'approcha brusquement, posa les deux mains sur les épaules de Mme de Clergerie, saisit dans le sien l'affreux regard vide, traversé d'ombres, et dit:

--Je n'ai pas peur, mama. Je n'ai pas peur de vous." ( $J$ 612)

Descriptions of Chantal's purity, which are often linked with the virtues of poverty and simplicity, resemble the mystical overtones characteristic of the medieval knight in search of the Holy Grail. She is described as "une petite pierre inaltérable, la très pure et très chaste humilité" ( $J$ 572). Her father compares her to a lily, a symbol of purity. ". . . tu pousses tout droit, comme un lis" ( $J$ 581). Chantal, oblivious to her own transparency, utters, "Il faudrait n'être qu'un cristal, une eau pure. Il faudrait qu'on vît Dieu à travers" ( $J$ 603). Desiring only to remain "docile à Dieu" (J 602), Chantal's love for God, her single-hearted 
motivating ideal, prompts her to generously love even the most wicked around her. A description of her attitude towards others links childhood with her spontanaeity, freedom and purity. ". . son indulgence envers chacun d'eux avait été celle d'un enfant, aussi spontanée, aussi libre, aussi pure" (J 602).

The curé himself defines his mission simply with the words, "Je suis le serviteur de Jésus-Christ" (JCC 1096). He moves through his daily duties like a faithful vassal to his lord. His diary is a mirror of his moments "sur la route" within "une paroisse comme les autres" (JCC 1031). As has been mentioned, the entries of this daily pilgrimage reflect an ordinary life, not only to its readers, but to himself (JCC 1036). His search for and maintenance of the truth is at the heart of this simple priest's quest. For truth is the only purifying force which can directly confront the adversary. The enemy in this novel is "l'ennui," a devouring, contagious "cancer" whose subtle symptom is mediocrity (JCC 1031). Its willing victims are lulled into a state of impurity which surreptitiously extinguishes a desire to know the truth of oneself before God. Its cancerous core is a lack of faith, a denial of God, "la Vérité, la vie." The young priest's recognition of the dangers at hand strengthen him for his own struggle. 
Ne serait-il pas plus juste de dire: la pureté ne nous est pas prescrite ainsi qu'un châtiment, elle est une des conditions mystérieuses mais évidentes--l'expérience I'atteste--de cette connaissance surnaturelle de soi-même, de soimême en Dieu, qui s'appelle la foi. L'impureté ne détruit pas cette connaissance, elle en anéantit le besoin. On ne croit plus, parce qu'on ne désire plus croire. Vous ne désirez plus vous connaître. Cette vérité profonde, la vôtre, ne vous intéresse plus. (JCC 1129)

Throughout the curé's search for truth evidenced in his written journey, the qualities of childlikeness play a significant role. His honest assessment of his own poverty of spirit is synonymous with childhood. - - je n'ai jamais douté d'avoir l'esprit de pauvreté. Celui d'enfance lui ressemble. Les deux sans doute ne font qu'un. (JCC 1246)

In a dialogue between the curé and his fatherly superior, M. le doyen de Blangermont, the latter affirms the sincerity of this little priest "d'un coeur d'enfant" (JCC 1155). Once again, the virtue of simplicity emerges as a major weapon against which the parishioners attempt to defend themselves. As suggested by the textual comparison between simplicity and the image of fire, this quality in 
the curé, similar to that of Donissan and Chantal, illumines the sinfulness of others.

D'être ce que vous êtes, il n'y a pas de remède à cela. Que voulez-vous, mon enfant, ces gens ne haissent pas votre simplicité, ils s'en défendent, elle est comme une espèce de feu qui les brûle. (JCC 1174)

Humbly, the curé recognizes his own insignificance as a defense. He writes: "Ou mon insignifiance, reconnue de tous, a-t-elle désarmé les soupçons, l'antipathie?" (JCC 1209) He is a "heroic child" first and foremost because he faithfully mirrors the qualities of childhood to the end. Even at death's door, he wants no part of praise or special recognition for his personal struggle and service to others. He remains a poor, humble, simple child whose death will reflect the truth of his life, the way of ordinariness. 12

L'héroisme à ma mesure est de n'en pas avoir et, puisque la force me manque, je voudrais maintenant que ma mort fût petite, aussi petite que possible, qu'elle ne se distinguât pas des autres événements de ma vie. (JCC 1245)

War language again abounds in the Journal. Expressions such as "lutter contre," "l'ennemi," "me défier en face," "recueille ses forces," "un gémissement 
de vaincu," among others, appear in descriptions of the curé's own personal struggle as well as in battles which erupt in others due to his saintly presence (JCC 1148).13 The curé, whose body is ravaged with cancer, symbolically embodies the double plane of battle. His own person becomes a reflection of the larger battlefield of a parish also ravaged by "ce cancer" (JCC 1032). Exteriorly, he sustains his frail, yellowing body and attempts to alleviate painful stomach cramps and nausea with a meager mixture of bread crumbs and wine. This nourishment, misjudged by others as evidence of alcoholism, is fuel for attack on his character. Ironically, these ingredients symbolize the Eucharist which, reminiscent of the medieval period, was a major weapon against demons. Moreover, these ingredients reflect the sacrificial role of the humanity of Jesus and are reminders of the call to imitation. The simple fare of bread and wine then link the curé closely to a christ figure as one strengthened for battle.

Tactics of the chivalrous child, who, step by step, brings sinful secrets of lying and hate-filled lives to the surface, are particularly evident in the curé's encounters with MIle Chantal and Mme la Comtesse (JCC 1132-39, 1145-64). Throughout the spiritual struggles of this novel, the allegiance of this chivalrous child is to 
the same ideal love of Donissan and Chantal. The God of truth is equally the God of Love. The curé unequivocally reminds Mme la Comtesse: "Il n'est pas le maître d'amour, il est l'amour même" (JCC 1158).

This chapter clarified the unifying aspects of the two background images, the way and the Mirror. Childhood, the bernanosian point of departure and the ultimate lucid reflection of oneself, was considered in relation to the medieval devotion surrounding the Infancy of Christ. This particular devotion emphasized the qualities of childlike poverty, humility, and simplicity. Demonstrating the Christocentric likeness of the three bernanosian characters to the Infant of medieval devotion, texts which reflect these central virtues were highlighted. A Christmas motif and its incarnational significance to the descriptive presentation of Donissan, Chantal and the curé d'Ambricourt were emphasized. In addition, textual samples of childhood themes of littleness and ordinariness which reflect virtues of the Infancy devotion were presented. Examples of double-planed imagery which comprise both earthly and mystical qualities were likewise discussed in relationship to the Infant imitation focus. Another quality surrounding the medieval Infancy devotion was that of tenderness. Examples of this virtue, set against the medieval edification theme where 
affectivity was a virtuous response, were found in the roles of "parent" characters, abbé Menou-segrais, abbé Chevance and the curé de Torcy. The three central child characters mirror their respective spiritual parent in their own individual role of Christlike imitation. Themes of chivalry infiltrate this devotion. The quest translates into a salvific role, the vocation of each character. Innocence and purity of heart are synonomous with the Divine Infant's virtues of poverty, simplicity and humility. In particular, simplicity is the major weapon with which to wage battle against evil. War language abounds in each novel and evil is present in different guises. The common allegiance of each "heroic child" is to their ideal, a God of Love. 
NOTES

1 Bernanos, "From Pirapora," décembre 1939.

2 Morris refers to the use of concrete objects such as rocks, stones etc. to describe abstract ideas. He quotes Bachelard who says "En s'exprimant par des images matérielles, par des images terrestres, . . il semble que les peines humaines deviennent plus lourdes, plus noires, plus dures, plus troubles, bref, plus réelles." Footnote 18, Gaston Bachelard, La Terre et les rêveries de la volonté (Paris: Corti, 1948) 1-2.

3 see Chapter I, "The Phenomena of Tears and Rain."

4 For Bernanos, the humility and innocence of childhood constitute "la juste voie de l'accomplissment chrétien." Yves Bridel, L'Esprit d'enfance dans l'oeuvre romanesque de Georges Bernanos (Paris:Minard, 1966) 248. In L'Imposture, Bernanos refers to "ce don sacré des larmes" as a "nouvelle enfance."

5 In this chapter, Bynum discusses the maternal role of the abbott in monastic communities. She also discusses the origin of the devotion to the Sacred Heart of Jesus and its maternal connotations.

6 Elsewhere Bernanos alludes to children as "enfants du choeur," "va-nu-pieds" (JCC 1037).

7 This theme of a newborn's beatitude is likewise described in Sous le Soleil 198. 
La première vision de l'enfant est mêmement si pleine et si pure que I'univers dont il vient de s'emparer ne saurait se distinguer d'abord du frémissement de sa propre joie. Toutes les couleurs et toutes les formes s'épanousissent à la fois dans son rire triomphal.

8 The mirror-like illumination of sin by the three main characters is discussed more at length in the last chapter of this study.

9 Ma fille, lui ai-je dit (le mot est venu de luimême à mes lèvres), on ne marchande pas avec le bon Dieu, il faut se rendre à lui, sans condition. (JCC 1161)

10 --Mon petit enfant, dit le vieux prêtre, que de périls vous attendent! Le Seigneur vous appelle à la perfection, non pas au repos. Vous serez de tous le moins assuré dans votre voie, clairvoyant seulement pour autrui, passant de la lumière aux ténèbres, instable. (SS 228)

11 See also: ( $J 671,676,697)$.

12 In the final chapter of this study, "I'enfance" mirrored in death is discussed.

13 See also: (JCC 1149, 1156, 1161, 1228). 


\section{CHAPTER IV}

\section{THE AGONY}

Bernanos understood his profession as a call to witness Christ. For him, this spiritual adventure was a challenge to work hard, to suffer much, to doubt oneself in success as well as in failure. Coupled with his own predisposition to suffer from anguish, his vocation to write was his way of the cross, his Calvary. In the process of this journey, Bernanos' Christian heroism is reflected through the sanctity and mysticism of his protagonists. Their mysticism is a place where more than the experience of divine essence is realized. The God of Bernanos' mystics is an incarnate one who undergoes his Passion, resurrects the dead, and becomes an ecclesiastic God (Von Balthasar 245). The childlike bernanosian protagonists whose poverty, humility and simplicity distinguish them from the common hero, experience a mystical night of the soul which mirrors medieval imitation of the sufferings of the human Jesus. This imitation, as Von Balthasar describes, reflects Jesus who assumes the burdens of the sinner and embraces the agony, the cross and the descent into Hell in a redemptive act. L'enfer que subissent les mystiques est souvent un enfer sans dêmon; il est la simple confrontation vécue avec cet immense péché du monde qui pèse de tout son poids et dont il est 
impossible de faire abstraction. (Von Balthasar $267-68)$

The "passion" of the bernanosian Christ figures is not for their own salvation. True to a medieval imitation of the Passion, they are motivated by the love of God which consumes them. Consequently, these chivalrous children do not suffer primarily for their own salvation, but for the redemption of others. Although Donissan, Chantal and the curé do not aspire to martyrdom, their pain, which so aptly reflects the distress and fear of their literary creator, is rooted in an interior martyrdom of anguish. Bernanos, l'ultime témoin des angoisses qu'il décrit, en est aussi le martyr. C'est sa faculté d'aimer et de souffrir, sa nostalgie des grandes routes désertées, c'est son enfance que retrouve en lui son évocation de la sainteté. . - (Moch 12)

Like the human Jesus, these bernanosian saints want the "cup of suffering" to pass. It is not the accusations, misjudgments and mistreatment by others which they fear, but a death which masks the reality of Divine Love. This death obscures forever the truth of oneself as a perfect image of Jesus. It is a death wherein the destination of fulfillment is forever lost in the dark and cold realm of untruth. This kingdom of lies is the world of satan where 
an imitation of Christlike perfection is distorted and where the Way becomes a treacherous labyrinth.

The main focus of this chapter is to demonstrate similarities to the medieval imitation of the Passion through an emphasis on the agony of each of the three main characters. The Mirror image emerges literally and figuratively. In the ongoing theme of imitation, its presence is constant. The image of the way is presented more directly in the discussion of the way of the cross. However, it should be kept in mind that each aspect of the Passion presented in this chapter is but a step on the pilgrimage towards Christian perfection.

In each of the synoptic Gospels, a description of Jesus' agony in the Garden of Gethsemani, the prelude to his crucifixion and death on the cross, is accompanied by expressions of human emotion. Jesus is sorrowful and troubled in Matthew (Matt. 26:37). Sudden fear coupled with great distress come over him in Mark's account (Mark 14:32). And anguish impels Jesus to pray more earnestly in the Gospel of Luke (Luke 22:44). In all three accounts, Jesus turns to his Father for comfort. In a paradoxical prayer, he pleads that this "cup" of suffering be taken away, yet, he expresses his openness to do his Father's will. Obedience and submission characterize the suffering Jesus of the synoptic accounts. Only in Luke's 
account is Jesus' anguish accompanied by sweat which "fell to the ground like great drops of blood" (Luke 22:44). These emotions and the obedient submission of Jesus as well as other characteristics related to the synoptic descriptions of the agony are reflected in unique ways in Bernanos' portrayal of his Christlike figures.

\section{The agony of Donissan}

Anguish, fear, submission, sweat and blood are part of Donissan's agony. In Sous le soleil de Satan, the title of the "Première Partie" of the novel, "La tentation du dêsespoir," provides a clue to this protagonist's suffering. Temptation in its most subtle form throws the unsuspecting Donissan into an encounter in the abyss of his own interior. A parallel to the three temptations of Jesus at the outset of his public ministry ${ }^{1}$ as well as to his threefold effort to rouse his sleeping disciples in the Garden of Gethsemane ${ }^{2}$ is captured symbolically in three stages of this bernanosian saint's agony.

First, Donissan's descent into despair is precipitated by a conversation with Menou-segrais on Christmas eve. Just as the crib was another Child's first step towards the cross, so too does the Nativity mark the naive curé's prelude to Calvary. Menou-Segrais starkly declares that Donissan's vocation is "Ia Sainteté!" Alone 
in his room, the echo of this shattering challenge to holiness resounds in Donissan's head: "Là où Dieu vous appelle, il faut monter" (SS 142). It is a vocational quest which exacts the epitome of humble submission (SS 139). But God's will for this simple soul overcomes him with an overwhelming fatigue (SS 142). At first, Donissan naively proceeds in blind obedience but not without an impending sense of distress (SS 142).

Alors, il se débattait en aveugle contre une tentation nouvelle plus dangereuse. Et son angoisse était de ne pouvoir la nommer. (SS 142) In the powerlessness of this anguish, which weighs him down with fatigue, he is stripped of all illusion to grandeur. The mirage of unrealized ideals is unmasked. The overwhelming truth of oneself paradoxically blinds and elucidates. The subtle darkness of despair dissipates defenses and the realities of his weaknesses are reflected in an unobscured mirror. In the following text, Bernanos' descriptive comparisons of the onset of despair unite death and childhood once again. This reiterated theme of self-knowledge reveals a little more about the narrator's series of personal interior crises.

Quelque chose de plus intime que la vie même était comme suspendue en lui. L'artiste vieillissant qu'on trouve mort devant l'oeuvre 
commencée, les yeux pleins du chef-d'oeuvre inaccessible--le fou bégayant qui lutte contre les images dont il n'est plus maitre, pareilles à des bêtes échappées--le jaloux bâillonné et qui n'a plus que son regard pour haïr, devant la précieuse chair profanée, ouverte, n'ont pas senti plus profonde la fine et perfide pointe, la pénétration du désespoir. Jamais le malheureux ne s'est vu lui-même (il le croit) aussi clair, aussi net. Ignorant, craintif, ridicule. . Hélas! ce que son mâttre distingue en lui, n'est-ce pas ce qui subsiste encore des dons jadis reçus, dissipés! La semence étouffée ne lèvera plus. Elle a été jetée pourtant. Mille souvenirs lui reviennent de son enfance si étrangement unie à Dieu et ces rêves, ces rêves-là mêmes--ô rage! (SS 142-43)

In Donissan's journey of suffering, each step thrusts him more into a land of exile (SS 143). Similar to Jesus whose attempts to awaken his companions to watch with him were unsuccessful, Donissan is without human companionship. Unable to raise his eyes towards the cross through which all is possible, he is even estranged from any divine consolation (SS 143). Instead, he is plagued by distracting interior voices of self-accusation "qui 
grondaient, sifflaient, grinçaient au coeur... avec une rage damnée. . ." (SS 144). Fear fills him with suffocating force. Suddenly he finds himself in a momentary oasis of complete silence.

L'intolérable sensation d'être pris au piège, de trouver dans la fuite un couloir sans issue, le mit soudain debout, le front glacé, les bras mollis, dans une inexprimable terreur. Et tout à coup le silence se fit. (SS 144) Alone in this silence, he waits, not with hopeful anticipation, but with dread foreboding. Almost imperceptibly, the waiting itself becomes the reality of a presence. Deceived, this tormented young priest perceives this presence as "le regard d'un ami." However, En détournant la tête, l'abbé Donissan ne rencontre aucun regard ami, mais seulement, dans la glace, son visage pâle et contracté. (SS 146) The literal mirror image of this passage unveils steps to Christlike perfection by disclosing a key factor in the bernanosian reality of suffering. Facing one's deepest self with an illuminating truth, is seemingly the purifying crucible for Bernanos' Christ figures. Because the tempter of bernanosian saints permeates their very saintliness, the core of their being, the struggle to 
perceive oneself truly is a simultaneous battle to disclose the deception of Satan, himself.

Cet homme incomparable qu'est l'abbë Donissan mérite un tentateur à sa mesure, l'indispensable rival de Dieu, dont la haine 's'est réservé les saints'.

'Il est dans l'oraison du Solitaire, dans son jeûne et sa pénitence, au creux de la plus profonde extase, et dans le silence du coeur. . .3

Seeing himself in the mirror, Donissan instinctively lowers his eyes. He is filled with uneasiness and doubt. Has his self-perception revealed the presence of another? For the second time, Donissan wants to pray. But his futile interior cry of distress dies in a muteness which announces the second stage of his agony.

This second effort to turn towards the Divine awakens a mysterious joy in Donissan (SS 147). But this is shortlived. Its unfamiliarity disconcerts him. And fear is again present.

L'âme aride, qui ne connut jamais d'autre douceur qu'une tristesse muette et résignée, s'étonne, puis s'effraie, enfin s'irrite contre cette inexplicable suavité. (SS 147) 
With discerning wisdom, Bernanos describes the seductive ruse of Satan, author of Donissan's strange sensible delight. Iike a beast hunting its prey, the devil craftily accompanies the saintly pilgrim each step of the perilous way. 4

Comme l'autre, qui s'est glissé entre Dieu et lui, se dérobe avec art! Comme il avance et recule, avance encore, prudent, sagace, attentif. . Comme il met ses pas dans les pas! (SS 147)

In this night of confusion accompanied by an illusory joy, Donissan suddenly recognizes his secret hope for sanctity which masks the presence of presumptive pride. Determined to dispel this temptation, "cette autre flamme du désespoir intrépide," Donissan succumbs to a calculated violence against himself (SS 148). Paradoxically, Satan turns the forceful weapon of self-infliction against him. Donissan, forgetting all recourse to the purifying fire of the Divine, is duped by the very pride he attempts to purge. ${ }^{5}$ The brutal self-flagellation resulting from an impetuous, self-reliant determination to purify himself mark the third stage of his agony.

Symbolically, Donissan is scourged by the hand of Satan. The presence which he feared in himself has momentarily overcome him. It surfaced as predatory pride. 
His instrument of torture, "une chaîne de bronze . . .," resembles Moses' rod which, in the old Testament, turns into a serpent when cast down (Exod. 4:2). Bernanos clearly compares "I'étrange discipline" to a snake (SS 148). "Chaque fois la chaîne sifflante, un instant tordue au-dessus de sa tête, venait le mordre au flanc, et s'y reployait comme une vipère. . (SS 149). He continues this analogical description. "La chaine était entre ses doigts raidis à chaque coup plus souple et plus vive, étrangement agile et perfide, avec un bruissement léger" (SS 150).

Blind to Satan's trap: Donissan struggles against interior illusions which Bernanos describes as the delirium of hope and the kiss of betrayal (SS 154). Against this deceptive joy, he wields the instrument of an inseparable enemy, his own demon.

- . il frappait sans relâche, trempé de sueur et de sang, les yeux clos, et seule le tenait debout, sans doute, sa mystérieuse colère. (SS 150)

Throughout the description of the scourging, Bernanos juxtaposes imagery of fire and cold which are both used negatively.

- - Satan is directly described as the essence of cold. . . Satanic fire attempts to mimic 
the love of God. It gives no light, but only destroys, leaving one cold and icy. (Morris 301) An oxymoron of fire/cold imagery sets the stage for the aforementioned subtle presence of evil throughout this scene. Mirror imagery likewise threads its way through this passage paralleling the evil presence with suggestions of obscured vision. Donissan's temptation is described as a flame. With a frozen face he snatches up the discipline and whips himself with a cold rage. The exterior landscape of snow and mud are juxtaposed with "Ie ciel livide" and "la clarté du jour" which suggest fire imagery. His pain, particularly across his closed eyelids, is described as "une flamme brève et haute. . . comparable au vertige du regard dans une lumière trop vive." His suffering is also compared to an unworldly fire which burns his eyes. His blind hate for himself is likened to a red fire which cannot be extinguished even with all the blood of the human race. At the end of this scene, Bernanos refers again to "la pâle clarté", "l'aube" which Donissan cannot see with his half-closed eyes (SS 148-51). In the throes of self-deception, his vision is blurred.

The aftermath of the flagellation is also replete with this same parallel imagery of fire/cold. But, it takes on new meaning. Donissan is no longer in delirium. 
He has passed through the pink fog of the bloody night (SS 149). His awakening is accompanied by the sun which permeates his room as well as the limpid sky outside. His eyes now open, he is astonished by the glistening stain of blood on the floor. Like his external vision which has become clear, his thoughts float in "une lumière si douce" filled with calm and lucidity (SS 151). Obscurity dispelled, he sees his own interior clearly.

Les derniers voiles étaient effacés, il se retrouvait lui-même, s'observant d'une conscience claire et active, mais avec un désintéressement surhumain. (SS 151)

A sun, already high in the sky, accompanies Donissan's efforts to move from his bed. The mirror on a table in his room reflects the external truth of what he has done to himself. What he sees is a nightmarish reflection. Ses flancs nus, sous la chemise en lambeaux, n'étaient qu'une plaie. Au-dessous de sein, la blessure saignait encore. (SS 152)

The pain he experiences is again likened to fire, a burning realization of what he has done.

Mais les déchirures plus profondes de son dos et de ses reins l'investissaient d'une flamme intolérable, et, comme il tentait de lever le bras, il lui sembla que l'extrême pointe de 
cette flamme poussait jusqu'au coeur. . . 'Qu'ai-je fait? répetait-il tout bas, qu'ai-je fait? (SS 153)

A lurking, hostile evil continues to accompany Donissan's self-awareness through several references to cold imagery. Like the biting satanic chain, the icy water bites his wounds. The elements of hot and cold encounter each other in his body as he trembles with feverish shivers. The winter wind laced with powdery snow whipping his cheeks with cutting air, is contrasted to fire imagery. ". . . il sentait ses yeux brûler dans leurs orbites comme deux charbons. . . il tenait âprement son regard fixé sur le clocher plein de soleil" (SS 152-53).

This "look," connected with fire imagery, becomes a positive precursor to his ability to look at the Cross, and perhaps to pray. At this point in the novel, Donissan, like Jesus, has passed through three stages in his agony. First, the burdensome challenge to holiness threw him into despair leaving him estranged from divine and human comfort and unable to pray. His second effort to turn towards the Divine was thwarted by a crafty, illusionary joy which led him into the tempter's trap of prideful purging. The third stage, marked by a lucid realization of self-deception, prepares him to face the 
cross. The action culminating these stages of Donissan's agony occurs when he symbolically climbs three steps to the altar and stops. "Alors, il regarde la Croix" (SS 153).

It is at this juncture that the readers are addressed directly. Momentarily leaving the scene of Donissan gazing at the cross, the narrator discloses the subtle ploy of satan in the soul aspiring to sanctity. The description is set in the context of mirror imagery wherein Satan becomes the perceived object of reflection. This tempter is adeptly painted as a surreptitious infiltrator into the core of sanctity. Fire imagery in this text necessarily carries a negative emphasis since the reference is clearly to satan.

Vos diableries sont à la mesure de vos nerfs fragiles, de vos précieuses cervelles, et le Satan de votre étrange rituaire n'est que votre propre image déformée, car le dévot de l'univers charnel est à soi-même Satan. Le monstre vous regarde en riant, mais il n'a pas mis sur vous sa serre. . . C'est en vain que vous le cherchez dans la chair plus secrète que votre misérable désir. . Il empoisonne l'eau lustrale, il brûle dans la cire consacrée, respire dans l'haleine des vierges, déchire avec 
la haire et la discipline, corrompt toute voie. (SS 154)

Returning to the scene of Donissan gazing, not at his own image in the mirror, but at the cross, Bernanos' text reveals a soldier struggling in the throes of battle. Donissan looks on "le Christ impassible" and pours out all the "violence" of his frenzied soul. Vulnerable, he declares himself unworthy of sanctity and begs for this call, this "cup" to pass. ". . . ne m'appelle plus!" (SS 154) He surrenders himself to the Crucified and renounces any aspiration to glory, to joy or to hope. Like a wounded child, he offers his life and even his salvation. Bernanos concludes this "Suscipiat" leaving little doubt that the submissive cry of Donissan is the prayerful plea of a saint.

Qu'ai-je à donner? Que me reste-t-il? Cette espérance seule. Retire-la-moi. Prends-la! Si je le pouvais, sans te haïr, je t'abandonnerais mon salut, je me damnerais pour ces âmes que tu m'as confiées par dérision, moi, misérable! Et il défiat l'abîme, il l'appelait d'un voeu solennel, avec un coeur pur... (SS 155) 
The agony of Chantal

Although Chantal's agony incorporates many of the same elements as Donissan's suffering, Bernanos parallels Chantal's suffering more explicitly to that of the human Jesus in La Joie. Similar to the emotional reactions and states found in the portrayal of Donissan's agony, Chantal likewise experiences anguish, fear, aloneness, vulnerability and surrender. However, unlike Donissan who is assailed by interior forces of evil in his agony, Chantal is primarily accosted by exterior malevolent forces (Morris 216). Anguish, fear and aloneness are initiated by a foreboding sense of betrayal from without. Similar to the agony of her spiritual father, Chevance, Chantal senses an impending peril and she is afraid, not of an interior force, but of something lurking in the shadowy environment around her. Her memories of Chevance's agony fill her with terror ( $J 676$ ). In the midst of her own absurd premonition, the recollection of her spiritual father's words on his deathbed give her courage.

En un sens, voyez-vous, la peur est tout de même la fille de Dieu, rachetée la nuit du Vendredi saint. Elle n'est pas belle à voir--non!-tantôt raillée, tantôt maudite, renoncée par tous. - Et cependant, ne vous y trompez pas: 
elle est au chevet de chaque agonie, elle intercède pour l'homme. ( $J$ 675)

In spite of this momentary consolation, she struggles with a rising panic in her aloneness. Feeling weak, powerless and trapped, she goes to her window. There, her own image, a reflection of fear, confronts her. She sees "grandir son pâle visage dans la vitre" (J 677). Wanting to flee, to escape from the terror of her premonition, she opens her door to leave but is greeted by suffocating shadows. Accustomed to finding peace and comfort in the consolation of contemplation, she is tempted to circumvent her fear by turning to the silence of prayer. Remembering previous advice of Chevance who counselled her to resist this form of escape, to remain calm in her forebodings, and to cease trying to understand her fear, Chantal recalls her spiritual father's description of Jesus' own human struggle with fear, a fear which heralds death.

Même la prière est parfois une ruse innocente, un moyen comme un autre de fuir, d'échapper--au moins de gagner du temps. Notre-Seigneur a prié sur la croix, et il a aussi crié, pleuré, râlé, grincé des dents, comme font les moribonds. ( $\mathrm{J}$ 675 )

Different from a Donissan whose bloody selfchastisement represents the agony of interior struggle, 
Chantal's agony involves an accumulation of exterior assaults on her person. Chantal's brutal whip is shaped from subtle forms of discouragement and misunderstanding while sharp thorns are represented by the obstacles placed in her path which weaken her body and test her spirit. Paradoxically, these debilitating forces prepare her to walk in the footsteps of Jesus as Saviour.

Le découragement de ces dernières semaines, les désillusions successives, la lutte qu'elle venait de soutenir contre Mme de Clergerie, La Pérouse, contre elle-même, lui apparurent comme autant de pièges, d'obstacles dressés sous ses pas afin d'user ses forces, de la réduire à l'impuissance dans le moment même qu'elle allait accomplir l'oeuvre unique pour laquelle elle était née: le salut des faibles êtres dont elle se sentait comptable à Dieu. ( J 680)

Like Jesus, Chantal chooses to remain defenseless in the face of the lies which surround her. Her truth and candor before M. La Pérouse echo the tribunal scene of the silent Lamb of the Gospels.

on n'a pas le droit de se défendre. . Dieu ne garde aucun de nous comme un oiseau précieux, dans une volière. . I I livre ses meilleurs amis, il les donne pour rien, aux bons, aux 
mauvais, à tout le monde, ainsi qu'Il a été donné par Pilate: "Tenez, prenez, voici I'homme!" ( J 672)

Chantal, image of the Sacrificial Lamb, undergoes the agony of a victim soul. Her purity equips her to withstand the milieu of lies and betrayal which surround her, but does not shield her from experiencing the weight of their sins which she, like Jesus, symbolically shoulders. Bernanos often uses water imagery to "transcribe the entire spectrum of spirituality, from the depths of sin and despair to purity and innocence" (Morris 155). Through the image of water weighing heavily upon her, Chantal is presented as the suffering servant, stripped and readied to be an instrument of salvation. - . elle crut entendre se refermer sur elle une eau profonde, et aussitôt, en effet, son corps défaillit sous un poids immense, accru sans cesse et dont l'irrésistible poussée chassait la vie hors de ses veines. Ce fut comme un arrachement de l'être, si brutal, si douloureux, que l'âme violentée n'y put répondre que par un horrible silence. . Et presque dans la même incalculable fraction de temps, la Lumière jaillit de toutes parts, recouvrit tout. ( J 681) 
Mystically engulfed in Divine Light, Chantal is a grace-filled instrument for others. ${ }^{6}$ Her "Fiat" to her Consoler is voiced with the simple expression, "M'Y voici" (J 681). In the midst of her ectasy with her eyes focused "un peu au-dessous de son crucifix" (J 682), this Christlike protagonist surrenders spontaneously.

- . c'était comme l'effusion hors de sa chair brisée, anéantie, du sang précieux d’un autre coeur. 'Je ne possède plus rien', pensait-elle avec une joie encore naïve et pourtant grave, auguste, qu'elle aurait voulu serrer farouchement sur sa poitrine, ainsi. . . S'il voulait, je pourrais mourir. . . (J 682)

This submission, even unto death, is reiterated in conjunction with an express reference to the crucified Jesus who shares his agony with her.

- . s'il plaisait à Dieu de détruire une misérable petite créature si parfaitement dépossédée, il devrait partager avec elle sa propre agonie, laisser prendre le dernier battement exténué de son coeur, le dernier souffle de sa bouche. Oui, elle recevrait la mort de cette Main qui ne peut plus se refermer sur rien, tenue ouverte par les clous, à jamais.

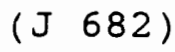


Like Jesus then, the saint of La Joie loses herself for others. The "Sainte Agonie" which she imitates, becomes a crossroad where the fear of death is reconciled in the context of Eucharist, the ultimate sacrifice of self. Echoes of Bernanos' own consoling confrontation with death at his first communion resound clearly in this novel, particularly in his treatment of "la sainte Agonie." In Chantal's perfect imitation of Jesus' agony, the sacrificial elements of the Eucharist emerge in descriptive passages. Chantal's suffering takes on the form of sacrificial bread. Similar to the symbolism of the medieval era, this bread, the Body of Christ, shields and strengthens.

- - elle avancerait pas à pas parmi les ténèbres d'une Agonie dont le seuil n'a encore été franchi par aucun ange; elle recueillerait chaque miette, à tâtons, de ce pain terrible. . - ( J 682)

This aspect of Chantal's suffering is parallelled with a bernanosian hymn of praise to an Incarnate Jesus whose sacrifice of self is primarily redemptive. This Christ is both the host of the Sacrificial Banquet of Holy Thursday ${ }^{7}$ and the human and divine savior of st. Paul's letter to the Philippians (Phil. 2:6-11). The Eucharistic theme of sacrifice is present through vineyard imagery 
which introduces the second key element of the sacrificial banquet--wine. Symbolizing "blood poured out" as well as "the cup" of the evangelical texts describing Jesus' agony in Gethsemane, this image is combined with a direct reference to Jesus' body, "le Corps sacré." Love, the motivating force for sacrifice, is linked to the earth with all its connotations of humility and simplicity. In the sacrifice of self-giving, monstrous fear is confronted, and conquered. Chantal emulates the model of this bernanosian hymn in her own agony. 8

Chantal's surrender to the struggle, her acceptance of each crumb of the sacrificial bread, brings an oasis of silence.

Et dans la même minute, le silence qu'elle appelait roula sur elle, la recouvrit. (J 682)

Unlike Donissan, the silence she experiences is not a hush of confused interior voices awaiting the blow of an invisible, treacherous tempter. Rather, her silence is the cessation of the sinful murmurings of the persons in her small universe ( $J$ 681). In her "solitude sans recours, éternelle" ( $J$ 681) which arises from the fleeting thought that God has abandoned those around her and that she is powerless to save them, her purity of heart instinctively prompts her to turn toward the Cross. Chantal's sense of abandonment, her thirst for consolation 
and the salvation of souls as well as her ultimate submission to the Divine, mark her as the exemplary mystic who re-enacts closely Jesus' final suffering on the cross. Elle leva vers le Christ pendu au mur un regard avide, et sans pouvoir se détourner plus longtemps de la source ineffable dont la soíf la dévorait, elle glissa sur les genoux, se jeta dans la prière, les lèvres serrées, les yeux clos, comme on tombe, ou comme on meurt. ( $\mathrm{J}$ 681) Morris describes Chantal's thirst as her desire to experience the same agony that Christ felt. He quotes Bernanos who says: "Certains êtres que rien n'assouvit ne sauraient trouver leur rafraîchissement dans l'eau vive promise à la Samaritaine, il leur faut le fiel et le vinaigre de la Totale Agonie" (qtd. in Morris 216).9 Chantal's mystical imitation of the suffering Jesus is likewise captured in her fall mentioned in this text. It is the mystical fall upwards already discussed in chapter III. Her likeness to death reemphasizes her total state of abandonment and self-giving (Morris 68).

The inclusion of the image of hardness so often used by Bernanos to announce or describe the presence of evil itself or any of its forms (pride, rejection of faith, etc.), is especially significant through contrast in a subsequent description of Chantal "dépouillée de tout 
autre sentiment, réduite à l'essentiel, lisse et nue, en effet, comme une roche usée par le flot" (J 682). 10 The stripped nature and pliability of "une roche," a type of rock found literally at "rock bottom," connotes the extent to which Chantal has surrendered herself to the movements of grace throughout her agony. In the perilous throes of dying to self, she is paradoxically bathed in life-giving grace. All that she has, her gift of self, her anguish, her doubts and even her remorse are plunged into "la prodigieuse compassion de Dieu" ( J 682). Docile to the movement of grace within her, and humbly aware of her unworthiness, ". . I'Agonie divine venait de fondre sur son coeur mortel et l'emportait dans ses serres" ( $J$ 683). As Chantal rests in prayer with a solitary God who consummates his human anguish in the Garden of olives, familiar elements of this scriptural night are mentioned in the bernanosian text. Blood, tears, the sound of a cock crowing and betrayal are present. In union with the Crucified, Chantal prostrates herself on the ground. Symbolic of Christ-like suffering being poured out in expiation for the sins of others, the earth, a symbol of sinfulness, drinks her tears "avec une avidité furieuse" ( J 683).

Hints of betrayal are heralded in a textual mixture of images which define the continual double-planed stage 
for bernanosian action. Light and shadows, hope and despair, the supernatural and real world of Chantal are ever-present. Into this setting, Bernanos interjects a question which is simultaneously Jesus' question as well as the silent query of the child saint who is caught up in the Divine agony. In the following text, Bernanos presents the deepest throes of Jesus' agony as a betrayal of love.

D'où va venir la trahison?

Car c'est à la trahison qu'Il pense, et elle y pense comme lui. C'est sur la trahison qu'Il pleure, c'est l'exécrable idée de la trahison qu'Il essaie vainement de rejeter hors de lui, goutte à goutte, avec la sueur de sang . . . Il a aimé comme un homme, humainement . . Ia manière d'un homme, mais comme aucun homme ne l'avait jamais aimé, ne l'aimerait jamais. Si purement, si étroitement, avec ce coeur qu'Il avait fait pour cela, de ses propres mains. ( $\mathrm{J}$ $683-84)$

In her mystical union with Jesus in his agony, Chantal experiences a lucid terror, one which Bernanos assures the reader, is not born of dreams. Contrary to the important emphasis placed on Donissan's ability to see the cross outside of himself, it does not matter whether 
Chantal's eyes see or don't see (J 685). She is bathed in mystical illumination which allows her to see beyond the external world. She recognizes a mirror-like image of herself in her own suffering which is identical with the suffering of her Model, Jesus.

La douleur fulgurante en était à ce degré de transparence et de pureté qui la fait rayonner bien au-delà du monde charnel. Et pourtant l'extraordinaire jeune fille reconnut la compagne fidèle, l'amie humble et sincère de sa vie, sa propre souffrance, dans cette espèce de miroitement prodigieux, insoutenable, qui était la souffrance même de Dieu. (J 685)

In the grace of union, Chantal's awareness of her oneness with Divine suffering reflects the bernanosian concept of "agony" which flows from the heart of self-knowledge. - . c'est du regard seul de Dieu que cette profondeur [l'abîme de la vie en Dieu] reçoit une plénitude débordante de signification qui déchire le réseau de la temporalité. De là vient le rôle presque démesuré que joue chez Bernanos l'agonie, comme lieu et comme heure de l'irruption de la vérité à chaque instant de la vie. . (Von Balthasar 50) 
Finally, vulnerable like Donissan, yet sustained in the grace of truth, Chantal renews her surrender. Her "Suscipiat" is equal to the desire of medieval martyrs prior to a fatal blow.

- - elle fit une fois de plus ce don ingénu de soi-même. Aucune des martyres qu'elle aimait n'embrassa le glaive ou la hache d'un plus gracieux abandon. A peine son visage eut-il une rougeur légère tandis que, du profond de l'extase, ses bras et ses épaules equissaient le geste de protéger, de couvrir une présence chérie, d'aller au-devant du coup fatal . • ( J 685)

\section{The agony of the curé}

The curé's agony is more plausibly portrayed in that the origin of his suffering emerges from the context of daily human experience. Hints of the dramatic assault of evil with which Donissan struggles as well as the purity of Chantal's mystical union in "La sainte Agonie" are tempered to the ordinary in Le Journal. A combination of internal as well as external elements contribute simultaneously to the curé's agonizing crucible.

The curé, a humble man of faith throughout the throes of his suffering, candidly acknowledges his primary role 
as a follower of Jesus. In his journal, his short sentence, "Je suis le serviteur de Jésus-Christ" (JCC 1096) is his reassuring self-perception which drives him doggedly forward in spite of his trials.

Physical pain is coupled with interior struggle. Not understanding the exact nature of his illness which causes him "d'affreuses douleurs d'estomac" (JCC 1055), the curé accepts his condition as coming from God.

Une douleur vraie qui sort de l'homme appartient d'abord à Dieu, il me semble. J'essaie de la recevoir humblement dans mon coeur, telle quelle, je m'efforce de l'y faire mienne, de l'aimer. Et je comprends tout le sens caché de l'expression devenue banale 'communier avec', car il est vrai que cette douleur, je la communie. (JCC 1096)

The expression "communier" connotes the receiving of the host. In the Eucharistic context, communion is the sacrifice of Jesus who offers his physical body (under the form of bread) and his blood (under the form of wine) for the strengthening and salvation of others. In this sacrifice, Jesus continues to share in human existence and the communicant enters into union with him. In the foregoing passage, the curé alludes to a Christocentric role wherein he embraces suffering which becomes a 
sacrificial offering for others. His nourishment of small portions of bread and wine, due to his illness, and the offering of the Holy Sacrifice of the Mass as a function of his priestly role symbolically unite the curé more poignantly with the Body and Blood of Jesus. He continually desires to follow Jesus' example of sacrifice, a way of being for others, in his own life.

The outward appearance of this simple priest is described as he looks at himself in a mirror. What he sees reveals vestiges of interior suffering and provides a first indication of his struggle to love himself.

En me rhabillant, je me regardais dans la glace, et mon triste visage, un peu plus jaune chaque jour, avec ce long nez, la double ride profonde qui descend jusqu'aux commissures des lèvres; la barbe rase mais dure dont un mauvais rasoir ne peut venir à bout, m'a soudain paru hideux. (JCC 1092)

Throughout the major part of his journey, sadness more than fear, accompanies the curé. It resembles the sadness of Jesus' agony as recounted in the Gospel text of Matthew.

And sadness came over him, and great distress. Then he said to them, 'My soul is sorrowful to the point of death.' . . And going on a little 
further he fell on his face and prayed. (Matt. $26: 36)$

The curé's exterior appearance marked by sadness elicits a nickname coined by the children in his parish. They call him "'Triste à vir' ce qui signifie en patois 'triste à voir"" (JCC 1109). Like a mirror which reflects the ravages of a spiritual illness, this sadness becomes the dark companion of the curé.

Nuit affreuse. Dès que je fermais les yeux, la tristesse s'emparait de moi. Je ne trouve malheureusement pas d'autre mot pour qualifier une défaillance qui ne peut se définir, une véritable hémorragie de l'âme. (JCC 1099)

As his daily struggle escalates, temptations to despair lurk around him. He writes that even the word "désespérée" horrifies him (JCC 1111). He recognizes sadness as the forerunner to a sin against hope, and names the origin of his inner affliction.

Le péché contre l'espérance--le plus mortel de tous, et peut-être le mieux accueilli, le plus caressé. Il faut beaucoup de temps pour le reconnâttre, et la tristesse qui l'annonce, le précède, est si douce! C'est le plus riche des élixirs du démon, son ambroisie. (JCC 1116-17) 
His mounting physical and spiritual anguish casts him into aloneness and solitude on a double plane. Exteriorly, his illness which is eventually diagnosed as stomach cancer, symbolizes the cancerous sinfulness infecting his parish. His disease not only causes him great physical pain, but creates emotional suffering as well. Just as Jesus suffered physically and emotionally for the sins of humankind, so does the curé redemptively assume the spiritual sickness of his parishioners. For example, his condition prevents him from eating properly and he can only tolerate meager portions of bread crumbs mixed with wine. Due to his cancer coupled with his simplicity and naive awkwardness, he becomes the target of ridicule and false accusations by both young and old parishioners. Among the rumors wielded through their scornful scourge of gossip, the curé is falsely labelled an alcoholic. Moeller summarizes the widespread derision inflicted upon this innocent priest.

Le mal se met à pulluler autour de lui; en apparence, le curé va d'échec en échec. L'institutrice lui écrit une lettre anonyme, le priant de s'en aller; le comte porte plainte auprès de l'évêque; Séraphita se moque de lui; le village tout entier le traite d'ivrogne. . . - (Moeller 390) 
The guileless curé finds consolation initially in the thought that "Les moines souffrent pour les âmes. Nous, nous souffrons par elles" (JCC 1052). His attitude towards the falsehoods and mediocrity of his parish is forecast early in his diary. It is a forgiving one, the same attitude of Jesus hanging from the cross who looks out at the face of the human race. The curé writes: "Pardonnez-leur parce qu'ils ne savent pas ce qu'ils font . . " (JCC 1052). He becomes an increasingly solitary figure in a parish which remains deaf and blind to his sincere intentions to minister.

Alors que je me croyais encore au seuil de ce petit monde j'étais déjà entré bien avant, seul-et le chemin du retour fermé derrière moi, nulle retraite. Je ne connaissais pas ma paroisse, et elle feignait de m'ignorer. (JCC 1102-03)

Similar to Jesus' solitude in Gethsemane, deprived of the comfort of his sleeping disciples, the curé reveals his isolation in the midst of his parishioners. J'étais si épuisé ce matin que j'aurais donné je ne sais quoi pour une parole humaine de compassion, de tendresse. (JCC 1100) Interiorly, the source of his strength diminishes with an ever-increasing spiritual dryness. Through mirror 
imagery which reflects the double-plane of his existence, the curé attempts to understand the meaning of his increasing distress.

Oh! j'ai connu des moments de désarroi, de détresse. Mais alors, et à mon insu, je gardais cette paix intérieure où les événements et les êtres se reflétaient comme dans un miroir, une nappe d'eau limpide qui me renvoyait leur image. La source est troublée maintenant. (JCC 1131)

He confesses that prayer has been little help in alleviating his suffering. With sheer will-power, he forces himself to pray, but he is estranged from any divine consolation.

- . d'abord posément, calmement, puis avec une sorte de violence concentrée, farouche... avec . . un emportement de volonté, dont tout mon coeur tremblait d'angoisse. Rien. (JCC

\section{1)}

The darkness of his spiritual anguish permeates his futile attempts to pray. His efforts take place during a dreadful night when his sleep is interrupted with nightmares (JCC 1111). ACcompanying his attempts to pray is a deluge of rain which represents the dark presence of evil (Morris 174). Desperately yearning for the ability to pray which is, for him, as necessary as air to his 
lungs and oxygen to his blood (JCC 1111), he laments that nothing familiar remains behind him. And in front of him, there is nothing except a black wall (JCC 1111). Continuing to grope in this darkness of the soul, his solitude turns to abandonment.

On ne prie jamais seul. Ma tristesse êtait trop grande, sans doute? Je ne demandais Dieu que pour moi. Il n'est pas venu. (JCC 1112)

The solitude and preliminary silence of abandonment converge into a darkness which becomes his spiritual night of the soul.

Même solitude, même silence. Et cette fois aucun espoir de forcer l'obstacle, ou de le tourner. Rien. Dieu! je respire, j'aspire la nuit, la nuit entre en moi par je ne sais quelle inconcevable, quelle inimaginable brèche de l'âme. Je suis moi-même nuit. (JCC 1112) Trapped in the stillness of his interior night, he wonders if he will be able to love anymore. Similar to chantal's posture of abandonment, the curé stretches face down on the floor. But unlike the perfect mystic whose action was pure, the more human curé realizes that he awaits nothing from God. Shamefully and scrupulously, he describes this act as a lie. 
The contrast of Chantal's suffering permeated with light images to the curé's agony of darkness is captured in a single image which Bernanos uses with both characters. In chapter III, the mystical implications of the "grain of dust" image were explained in reference to Chantal. In Le Journal, the same image is used twice successively. At first, the curé likens his past to a "grain of dust" bearing characteristics of light.

Il me semble avoir fait à rebours tout le chemin parcouru depuis que Dieu m'a tiré de rien. Je n'ai d'abord été que cette étincelle, ce grain de poussière rougeoyant de la divine charité. ( JCC 1113)

In the subsequent use of this same image, it dissipates into the darkness.

Je ne suis plus que cela de nouveau dans l'insondable Nuit. Mais le grain de poussière ne rougeoie presque plus, va s'éteindre. (JCC $1114)$

In both instances, the image carries connotations of humility, simplicity and charity.

The profound silence of the cure's anguish is heralded by some stark insights concerning the truth of oneself. First, purity allows faith, "cette connaissance surnaturelle de soi-même, de soi-même en Dieu. . ." (JCC 
1129). Impurity impedes the desire to know one's deepest self. As a result, one denies oneself, one's joy and the ability to love oneself.

Vous ne pouviez vous aimer qu'en Dieu, vous ne vous aimez plus. Et vous ne vous aimerez plus jamais en ce monde $\mathrm{ni}$ dans l'autre-éternellement. ( JCC 1129)

This passage culminates with an admission of his extreme anguish which cloaks his very being in silence.

J'ai écrit ceci dans une grande et plénière angoisse du coeur et des sens. Tumulte d'idées, d'images, de paroles. L'âme se tait. Dieu se tait. Silence. (JCC 1129)

In this state, he awaits what he describes as "la véritable tentation." The style of his diary entries at this point provides the reader with an impression of a halting, yet stealthy approach of a monstrous threat in the dark paralysis of his anguish (JCC 1129-30). This anguish, like that of Chantal, is in union with "la Sainte Agonie." The difference in the two novels is that the curé is unaware of this fact until, in the midst of a visit with his old friend, the curé de Torcy, he suddenly realizes the origin and reason for his suffering, a realization that comes to him in a very natural and familiar movement of the soul. 
La vérité est que depuis toujours c'est au jardin des oliviers que je me retrouve. . N'est-ce pas assez que Notre-Seigneur m'ait fait cette grâce de me révéler aujourd'hui, par la bouche de mon vieux mâ̂tre, que rien ne m'arracherait à la place choisie pour moi de toute éternité, que j'étais prisonnier de la Sainte Agonie? (JCC 1187)

Although fear is not mentioned in the dark agony of the cure, it is present later when confronted with death. After the sudden death of Mme la Comtesse, the curé sees his own image, deformed by fear, reflected in mirrors and windows:

Cette détresse honteuse était si grande, que je ne pouvais pas m'empêcher de grimacer. Je voyais dans les glaces, les vitres, un visage qui semblait défiguré moins par le chagrin que par la peur, avec ce rictus navrant qui demande pitié, ressemble à un hideux sourire. Dieu! ( JCC 1166)

The fear of death, blood, and an image of scourging are connected to the "Holy Agony." The mention of the latter incorporates a tone of supplication and consolation. The fleeting experience of fear in the following scene is one 
of lucidity and acceptance, unlike the foregoing descriptions of dark anguish.

Encore une petite hémorragie, un crachement de sang, plutôt. La peur de la mort m'a effleuré. Oh! sans doute, sa pensée me revient souvent, et parfois elle m'inspire de la crainte. Mais la crainte n'est pas la peur. Cela n'a duré qu'un instant. Je ne saurais à quoi comparer cette impression fulgurante. Le cinglement d'une mèche de fouet à travers le coeur, peut-être?. - O Sainte Agonie! (JCC 1209)

Fear is mentioned again, not directly in relation to death, but as its precursor. It emerges in a passage which serves as a framework for the place and reality of the curé's own mortal death. 11 As he enters the old church, there are too many people there. This external crowd mirrors an internal image of fear which is precipitated by a desire to prostrate himself on the church floor. But his desire becomes a twisted revolt against prayer and once again, the curé experiences the anguish of absence.

Car je ne luttais pas contre la peur, mais contre un nombre, en apparence infini, de peurs-une peur pour chaque fibre, une multitude de peurs. Et lorsque je fermais les yeux, que 
j'essayais de concentrer ma pensée, il me semblait entendre ce chuchotement comme d'une foule immense, invisible, tapie au fond de mon angoisse, ainsi que dans la plus profonde nuit. (JCC 1228)

According to Brian T. Fitch, this night of interior darkness still present reflects an emptiness - . où il lui semble que Dieu l'a abandonné; alors, sa vie intérieure s'impose à lui comme un gouffre ténébreux, puisque sa conscience est uniquement conscience d'une absence. . . . ("Aspects de la structure. . ." 90-91)

The sweat of his agony is contrasted with the cold which assails him when he leaves the church. As mentioned previously in the discussion of Donissan's temptation, the cold is generally used by Bernanos to indicate the presence of evil, of darkness.

La sueur ruisselait de mon front, de mes mains. J'ai fini par sortir. Le froid de la rue m'a pris. . . ( JCC 1228)

As the text continues, a second crowd, a noisy one outside the church is present and amidst this motley populace, the curé's darkness is lifted.

Mais je ne sentais qu'une légèreté incompréhensible. Ma stupeur, au contact de 
cette foule bruyante, ressemblait au saisissement de la joie. Elle me donnait des ailes. (JCC 1228)

The placement of these two crowds side by side in this text prepares the way for the bernanosian themes of "le silence qui nous garde" and the communion of saints. (JCC 1229) Both of these themes converge in the context of death and transformation, subjects which are discussed in the last chapter.

Another text uniting agony and fear occurs towards the end of the novel. The agony described in this passage no longer reflects the shadows of night, but is seen in its glorified reality. It is an act of love. Fear is seen here as the "friend.. ." which Bernanos identified in La Joie. It is a fear which, in the spirit of the old Testament, is the beginning of Wisdom. Fear becomes the helpmate which readies the soul to look upon one's own truth which, according to Bernanos, can be truly seen only in the face of Divine Love.

- . I'agonie humaine est d'abord un acte d'amour. . Pourquoi m'inquiéter? Pourquoi prévoir? Si j'ai peur, je dirai: j’ai peur, sans honte. Que le premier regard du seigneur, lorsque m'apparaîtra sa Sainte Face, soit donc un regard qui rassure! (JCC 1256) 
This fear is then, a fear filled with hope in the heart of "La Sainte Agonie."

In chapter four, the primary focus has been on the unique modelling of Jesus' Agony by Donissan, Chantal and the curé. Motivated by the love of God, each of these chivalrous children enter the battle against evil through a painful experience of interior anguish.

Donissan's anguish originates in the depths of his soul as he struggles with the temptation to despair. Isolated and confused, he tries to see himself clearly, but his mirror of self-knowledge is obscured by an insidious presence of evil which hides in his own pride. Fire/cold imagery enhances the drama of the abbe's conflict. With scrupulous and ruthless strokes, he flagellates himself in a bloody attempt to purge himself of pride. In the aftermath of his impulsive actions, his vision, both spiritual and physical, clears. It is only when he can focus on the cross, that he is empowered to pray. He begs that his "cup" of suffering pass. And like his Model, Jesus, he surrenders obediently by offering his entire being as well as his own salvation with a pure heart.

Chantal, a holy victim like the medieval martyrs, is accosted by exterior forces of evil. She becomes the Sacrificial Lamb offered as victim in the Eucharist and on 
the cross. Isolated like Donissan, her agony is a struggle with fear. Impending peril haunts and terrorizes her. The lies and betrayal that surround her are confronted with her purity. Empowered in mystical prayer, this Christ figure shoulders the weight of the sins around her. Light, water, earth and rock imagery, as well as the symbolic elements of the Sacrificial Banquet, add descriptive force to the characterization of Chantal as the mystic saint united with Jesus in his agony. In the lucidity of mystical illumination, she recognizes that her suffering is identical with the agony of Jesus.

Vulnerable, yet empowered by her union with her Model, she surrenders herself to the fatal blow.

The curé's agony is like Chantal's, identical to the suffering of Jesus in the Garden of Olives. However, unlike the mystic saint of La Joie, the curé is unaware of this identity with Jesus' agony until much later in the novel. His suffering is rooted in the ordinariness of the human condition. Physical pain due to a stomach cancer is accompanied by an interior struggle of sadness which borders on despair. Themes of darkness, silence and cold accompany textual allusions to the curé's interior struggle as well as with his ability to know and love himself. Similar to Donissan and Chantal, the curé is also isolated. He too is victimized by his parishioners 
who scourge him with malicious gossip and ridicule. Fear accosts the curé in relation to death, but does not play a major role in the dark anguish of sadness. In this novel, it becomes the positive force accompanying the agony of Jesus. The curé, in his ordinary way, accepts fear just prior to his death. This hope-filled act provides evidence of his surrender to Divine love. 
NOTES

1 Matt. 4:1-11; Mark 1:12-13; Luke 4:1-13.

2 Matt. 26:36-46; Mark 14:32-42; Luke 22:40-46.

3 See Bernanos, Sous le Soleil (Paris: Plon 1926)

138, qtd. in Moch, La Sainteté 80 , see footnote \#41.

4 see Bernanos, sous le soleil 147.

Le pauvre prêtre croit flairer le piège tendu, lorsque déjà les deux mâchoires l'étreignent, et chaque effort les va resserrer sur lui.

5 Morris, From Heaven to Hell 301. "Divine light and fire also act harshly on the sinner, yet purify by destroying evil."

6 See Bernanos, La Joie 681. Chantal becomes an instrument of grace through the fruits of her contemplation described as: ". . . ce regard intérieur qui baignait dans un autre jour."

7 Matt. 26:20-29; Mark 14:17-25; Luke 22:14-23; John $13: 17-26$.

8 Bernanos, La Joie 684. The following is the text of the bernanosian hymn of praise to a redemptive, incarnate Jesus. In addition to the underlying importance in the textual creation of Chantal's agony, it also reflects Bernanos's source of consolation and hope, the Incarnate Jesus in the Eucharist, as he personally struggled with the fear of dying. 
Lui, cependant, bénissant les prémices de sa prochaine agonie, ainsi qu'Il avait béni ce jour même la vigne et le froment, consacrant pour les siens, pour la douloureuse espèce, son oeuvre, le Corps sacré, Il l'offrit à tous les hommes, Il l'éleva vers eux de ses mains saintes et vénérables, par-dessus la large terre endormie, dont il avait tant aimé les saisons. Il l'offrit une fois, une fois pour toutes, encore dans l'éclat et la force de sa jeunesse, avant de le livrer à la Peur, de le laisser face à face avec la hideuse Peur, cette interminable nuit, jusqu'à la rémission du matin. Et, sans doute, Il l'offrit à tous les hommes, mais Il ne pensait qu'à un seul. Le seul auquel ce Corps appartint véritablement, humainement, comme celui d'un esclave à son maître. . Le seul ainsi qui pût défier la miséricorde, entrer de plain-pied dans le désespoir ainsi que le premier meurtrier s'était ouvert de la nuit. Le seul homme entre les hommes qui possédât réellement quelque chose, fût pourvu, n'ayant plus rien désormais à recevoir de personne, éternellement. 9 see footnote \#93, qtd. in Gaucher, Le Thème de la mort 76 .

10 Morris, From Heaven to Hell. See Chapter I, "Satanic Hardness" 15-26. 
11 H. Aaraas, Littérature et sacerdoce (Paris:

Minard, 1984) 127-28.

- - les lieux de l'écriture sont expressément nommés et la divisent en deux: l'estaminet de Mme Duplouy (voir 1227-42) et le logement de M. Dufréty (voir 1242-58), à minuit, dans la chambre où il va mourir. . . Ce récit est organisé autour de deux visites dans une église, la même, chaque fois avec un résultat négatif (voir 1228, 1231). 


\section{CHAPTER V}

\section{THE WAY OF THE CROSS}

The Passion of the bernanosian saints is a lifelong pilgrimage. Their way of the cross is not the final culmination of their agony as it was for Jesus. However, Donissan, Chantal and le curé reflect the suffering Servant, who, "bearing his own cross" (John 19:17-22), made his way to Golgotha where he suffered and died for the salvation of others. His death, an expiation for the sins of the world, is reflected in the burden of sinfulness carried by each of Bernanos' Christ figures. Although each of them experiences the cross in the continual conversion process of the Way, a particular scene exists in each novel which reflects more literally Jesus' Way of the cross. Each of these scenes contains accompanying elements which provide a backdrop unique to each novel and consequently unique to the way for each character. Both the elements of each character's Way and their more literal imitation of Jesus' Way of the cross are the main emphases of this chapter.

\section{Donissan's Way of the cross}

Donissan's Way of the cross is literally and figuratively circular. While encompassing many of the aspects described in Donissan's agony, particularly the struggle with temptation, his Way also reflects an 
external resemblance to Jesus' way of the cross. Donissan's Way is a circuitous route. It ends with his direct encounter with Lucifer, the prince of darkness. This climactic struggle is, like Jesus' struggle, victorious.

The way considered in a literal sense is the first focus of this section. Secondly, elements which provide a backdrop for the Way as well as staging for Donissan's encounter with evil are highlighted. Finally, Donissan's "chemin" and its similarity to Jesus' Way to Calvary is demonstrated.

The way itself is characterized in both a descriptive and rhythmic fashion. With punctuated, moving phrases, Bernanos provides the reader with a literal description of Donissan's road. "Devant lui, la route plongeait maintenant vers la vallée, entre deux hauts talus, semés d'une herbe courte et rare" (SS 163). As the abbé sets out, it is "sur une route irréprochablement unie, à pente très douce, au sol élastique" (SS 163). Inadvertently, he turns off the main road to a shortcut. This pathway is not often used. It passes by a cemetery and ends at the mouth of the neighboring church where he is awaited to help with confessions. In the description of this detour, allusions to death and final destination are already apparent. The soil on this unfrequented path is 
surprisingly even and firm (SS 163). However, the shortcut takes the abbe mysteriously back to his starting point. He determines not to leave the main road which has become a rougher terrain at this point. As he walks, he feels "sous ses grosses semelles, le sable trempé de pluie" (SS 164). The next description of the road is a figurative one. Bernanos animates the way and his choice of words alludes to snake-like imagery which interacts with an increasingly vulnerable Donissan. "La route s'allonge et glisse sous lui, comme si elle le portait. . .--droite et facile, d'une pente si douce. . ." (SS 164). Subtly, this image alerts the reader to a dangerous presence. In addition, the escalation of hostile expressions and obstacles along "la route" such as "l'herbe glacée," "rameaux invisibles," "un petit fossé," "la boue froide," "une haie épaisse et courte hérissée d'épines," (SS 165) augment the suspense. The reference to cold imagery is reminiscent of Bernanos' inclusion of an evil presence.

The rhythm of the way is captured in this text by repetition, pauses and sequences of short phrases. At first, Bernanos sets a more rapid pace with a short phrase followed by a longer explanation: "Il se mit à marcher--ou plutôt il lui sembla depuis qu'il avait marché très vite. - ." (SS 163). In the second phase of Donissan's circular 
journey, the initial sentence is longer and is followed by successive shorter phrases. This contributes to a slower pace which matches the action of the main character: "Il se remit en marche aussitôt bien décidé à ne plus quitter la grande route. Il marchait cette fois lentement, tenant son regard fixé devant lui, . . ." (SS 164). A syncopated series of phrases resemble the hesitant steps of Donissan: "Se dressant debout, en gémissant, il fit encore quelques pas, cherchant à deviner la ligne de l'horizon, tournant sur lui-même" (SS 165). These linguistic elements contribute to the abbé's mounting frenzied pace bordering on panic. "Une fois de plus il s'engage dans le chemin, descend la pente, d'abord lentement, puis plus vite, et plus vite encore, enfin tout courant" (SS 166). Finding himself at his starting point for a second time, he undertakes his journey once again with controlled calm. Short phrases resemble his methodical and determined footsteps and also interrupt the flow of his pace like the obstacles described. "Il avance d'un pas régulier, docile dans la terre qui colle à ses semelles, enjambe des haies basses, une clôture en fil de fer, évite d'autres obstacles, à tâtons, sans tourner la tête, de nouveau infatigable" (SS 167).

From the outset of this passage, exterior darkness and heaviness mark the context of the abbe's pilgrimage. 
The countryside before him is already "trois quarts englouti dans 1'ombre" (SS 163). Almost immediately, Donissan looks for familiar landmarks "à travers la nuit" (SS 164). Descriptions of night abound. The "ciel noir" (SS 164) which becomes the "nuit close" (SS 164) symbolically represents his circular route. As a foreshadowing of the abbé's encounter with the beast of darkness, the blackness of the night seems to stalk its prey. This image is coupled with a heaviness already hinted at with the expression, "les ténèbres si épaisses" (SS 164). Donissan quickens his pace to avoid being swallowed up by "cette nuit noire qui s'ouvrait et se refermait derrière lui si étroitement qu'elle semblait peser" (SS 164). The reiteration of the beast-like image prolongs a sense of persistant pursuit. "Il presse le pas et toujours la nuit s'ouvre et se referme" (SS 164). As the text continues, images of the night mirror interior implications. Unifying the external landscape, "la plaine immense," with the increasing confusion of the abbé, Bernanos makes a gradual transition from the exterior night cloaking the pilgrimage to an inner night of the pilgrim's own emptiness (SS 165). The image of heaviness continues to be present in this transition. This time it is a sleepy heaviness which overcomes Donissan and fills him with uneasiness. In turn, the disquiet or interior 
darkness takes on beast-like qualities. ". . elle s'empara de lui tout entier. Elle était comme un cauchemar lucide, qui rongeait peu à peu son sommeil. . . (SS 165). Later in the text, Bernanos leaves no doubt that this extreme darkness is present on two planes. It simultaneously surrounds the abbé and is present in his soul: "Si épaisse que soit la nuit qui l'enveloppe, audehors et au-dedans. . ." (SS 171).

Another element which marks Donissan's pilgrimage is silence. Like the initial darkness, it is an external silence. Bernanos' description of this element also includes a suggestion of heaviness.

- - le profond, l'épais silence n'était plus traversé d'aucun bruit. . . Il n'entendait, en prêtant l'oreille, que le vague frémissement de la terre, perceptible à peine, et si monotone que l'extraordinaire silence s'en trouvait accru. D'ailleurs, ce murmure même cessa. (SS 163)

The accompanying wind, soundless, strikes the curé in the face with its coldness (SS 166). It is the herald of another unannounced companion whose initial presence, "dont il distingue mal la silhouette" (SS 167), accompanies the abbé without breathing a word (SS 167). The person of this "petit noir marcheur" embodies the 
unification of darkness and silence. Likewise, the "glissement" of the abbé into profound silence is likened to characteristics of darkness: "Les ténèbres où il s'enfonçait sifflaient à ses oreilies comme une eau profonde" (SS 172). Yet another example of the juxtaposition of these two images is found in the unspoken query, "A-t-on besoin de se connaitre pour aller de compagnie, à travers ce grand silence, cette grande nuit?" (SS 167) At this juncture, the external and internal dimensions of night and silence merge. Their meaning is imbued with an evil presence which marks Donissan's agony. However, unlike the agonizing prelude to this pilgrimage where the abbé was grappling with an invisible, deceptive force, he is now faced with a visible tempter. The scene is set for the entrance of this evil entity. From the beginning of Donissan's journey, cold images are abundant. As has been discussed in chapter four, the bernanosian Satan is the essence of cold. We have already glimpsed two instances of "cold" in this text: the icy wind and the frozen grass. Initially, cold mud (SS 166) becomes frozen mud (SS 175). As the pilgrimage progresses, cold imagery moves from the external setting to the person of the abbé. "Toutefois sa fatigue était si grande que le froid l'avait saisi: il grelottait dans sa soutane trempée de sueur" (SS 165). With the appearance of Satan, cold imagery 
escalates with rapidity. Some of these expressions include: "Homme de neige," "Il y a de quoi se geler le sang," "un grand frisson," "comme s'il eût plongé lentement dans une eau profonde et glacée," "Je résiste au froid," "J'ai froid" (SS 175). The accumulating cluster of these images is crowned with the chilling confession of the mascarading "maquignon" (SS 174). He states: "Je suis le Froid lui-même. L'essence de ma lumière est un froid intolérable. . " (SS 175).

Prior to the direct encounter with evil, Donissan's pilgrimage strikingly reflects the way of the cross. At first, he is full of zeal and energy in both mind and body. His energy is compared to the freshness of the morning (SS 164). In bernanosian imagery, this time of day signals the presence of grace. The abbé's demeanor contrasts sharply with the exterior circumstances. In spite of the darkness, he sees clearly (SS 164). When he discovers that his pathway has led him back to his initial place of departure, his reaction is one of surprise and calm. In his renewed effort to follow the road, he proceeds more slowly. But in contrast to the mounting hostility of the elements around him, he experiences no anguish. Becoming disoriented due to his obscured vision, however, his initial energy and lucidity dissipate into an illusion. Physically, he begins to suffer. His heart 
pounds and he is covered with sweat. ". . il se sentit recru de fatigue, les jambes raides et douloureuses, les reins brisés. Ses yeux, qu'il avait tenus grands ouverts dans les ténèbres, étaient maintenant pleins de sommeil" (SS 165). Although he does not yet experience fear, he is vexed and feels the weight of his drowsiness and the cold. Under this weight, he cannot keep himself from sliding a first time. Filled with a vague and confused misgiving, he keeps his eyes shut for fear of "le choc d'une vision imprévue et terrible" (SS 166). When he does open them, "il s'aperçut simplement qu'il était revenu, pour la deuxième fois, à son point de départ, exactement" (SS 166). So stunned by this deception and inability to progress, he remains crouched in the cold mud incapable of any movement or thought. (SS 166) When he is able to move, he inspects and reinspects the area he has travelled trying to break the circle. The bernanosian description of his search skillfully mirrors a previous description of the scrupulous priest who methodically tries to root out his every flaw like "un lutteur qui ménage des forces" (SS 161). Symbolically bent under the weight of his own sinfulness, he searches in vain for his mistaken turn. Il marchait de long en large, courbé en deux, tâtant parfois le sol de ses mains, s'efforçant de retrouver sa propre trace, de la suivre pas à 
pas jusqu'au point mystérieux où il avait dû quitter la bonne voie pour, insensiblement, lui tourner le dos. (SS 166)

Unsuccessful, Donissan is filled with discouragement and despair. His eyes well with tears. Undertaking his journey once again, however, his simplicity motivates him to conquer the obstacles of illusion and deception. His intent this time is not so much to reach his destination, but to flee from his own terror. Likened to a ghost, "si drôlement actif et gesticulant, à travers les choses immobiles" (SS 167), he crashes into a cold wall and slides for the second time into the frozen mud. The use of cold imagery signals the continued presence of evil while the abbé's fall resembles Jesus' memorable journey to Calvary. Eyes closed, and bewildered, Donissan realizes that he has once again completed a circular route.

As the struggling abbé lifts himself up again, it is as though a burden rests on his shoulders. In the docile steps that follow, Donissan mirrors Jesus carrying His cross.

Il se relève, avec un profond soupir et, d'un geste des épaules, comme pour assujettir son fardeau, se remet en marche, tournant décidement le dos. (SS 167) 
Shortly thereafter he is accompanied by the disguised Satan, who, with false solicitude, "couche presque de force son compagnon" (SS 171). Humiliated and attempting to rationalize the apparent kind actions of this deceptive companion, Donissan attempts to get up. He is filled with feelings of intuitive resistance. But, again, like Jesus, he falls a third time. "Il secoua la tête, fit un effort pour se dresser debout et, pesamment, retomba" (SS 171). A subsequent fall is a symbolic one. "Il lui sembla qu'il glissait dans le silence, d'une chute oblique, très douce" (SS 172). Held in an embrace, unknowingly face to face with deception itself, he struggles against the treacherous support. The tree-like image which Bernanos introduces in a brief description of this embrace elicits a paradoxical association with the wooden cross of Jesus. "Le torse qu'il pressait ainsi était dur et noueux comme un chêne" (SS 172). Embracing the cross, Jesus conquered sin and death. And from its height He descended into hell before he rose again. In this text, Donissan is held by the enemy over an apparent abyss (SS 177). His recognition and struggle with the satanic seducer of souls is a battle against his own fear, anguish and terror. The struggle escalates to the supreme test. The enemy, disguised with Donissan's own flesh, becomes a transparent double which the abbé must deny. 
Et le vicaire de Campagne vit soudain devant lui son double, une ressemblance si parfaite, si subtile, que cela se fût comparé moins à l'image reflétée dans un miroir qu'à la singulière, à l'unique et profonde pensée que chacun nourrit de soi-même. (SS 180)

The brusque words, "Retire-toi, Satan!" (SS 181) ring victoriously. In a symbolic gesture, the curé pushes "la chose frémissante" out of his path (SS 181). This is the last time "la route" is mentioned in the text. The struggle with Satan concludes and Donissan emerges as a true disciple strengthened for other encounters along his way. In unison with the Gospel message, "If any man would come after me, let him deny himself and take up his cross and follow me" (Matt. 16:24) this Christlike figure's subsequent journey leads him to imitate Jesus in an ongoing struggle for the salvation of others.

\section{Chantal's way of the cross}

Bernanos' description of Chantal's way of the cross includes literal and figurative dimensions, but not to the extent of the way in sous le Soleil de Satan. Her path is not a journey of interior struggle like Donissan's, but a response to the external need of others. Through her mysticism, Chantal is groomed for an altruistic journey 
which leads to the disclosure of sinfulness and saving grace. The actual descriptive texts where this Christocentric figure resembles Jesus carrying his cross appear in two brief sections of the novel. The first section is the beginning of a conversion process. Its conclusion is not described until much later in the text. In this discussion, emphasis will be given first to the backdrop elements of the way. This will be followed by a description of the cross Chantal carries as well as her Christ-like imitation in the conversion process.

In contrast to Donissan's journey which begins at night and is continually surrounded by darkness, Chantal's Way of the cross occurs at noon in the heat of the day. This is a fitting backdrop for the Christ-like action of the mystical heroine who is continually characterized by light and fire imagery. Allusions to the warmth and light of a summer's day ( $J$ 613) punctuates the text through expressions such as "le soleil pique" (J 607), "le feu liquide du ciel" ( $\mathrm{J}$ 608), and "la lumière de midi" ( $\mathrm{J}$ 608). Contrary to a potentially negative interpretation of the unmerciful heat and light continually represented, the "ciel torride" and "les rets de flamme du paysage" reflect a purifying fire (J 611). Consistent with bernanosian double-planed imagery, the "impitoyable 
lumière" is a powerful force which reveals hidden evil ( $614)$.

Car elle n'arrivait pas encore à détacher ses yeux de la tête ennemie, assaillie par toute la puissance du jour, dépouillée même de cette ombre secrète... ( J 614)

The elements of night, heaviness, silence and cold are present in this text in a figurative sense. Each of them emerges in descriptive passages of Chantal's grandmother. She personnifies a burden which symbolically represents the sinfulness in Chantal's universe.

This frail, disoriented woman is shrouded with a night of dark secrets. Through her past sins, she has created her own night.

Elle serrait plus étroitement les doigts sur ses yeux comme si la nuit qu'elle faisait ainsi en elle l'eût rapprochée de la chère morte . . . ( б10)

The grandmother is also described as "noire et menue devant cet horizon immense. . ." (J 611).

Chantal, whose purity and light pierce the darkness around her, senses the sinful heaviness in her grandmother. 
Il y a quelque chose, je ne sais quoi, qui pèse trop lourd en vous, dans votre pauvre âme, estce vrai? ( $\mathrm{J}$ 612)

This heaviness is symbolized by the keys which Chantal's grandmother clutches. Chantal illumines their negative significance in a comparison which highlights the element of heaviness:

Chacune d'elles est un petit démon, et chacun de ces petits démons est, à lui seul, plus lourd qu'une montagne. Avec un poids pareil, ma pauvre mama, quand les anges s'y mettraient tous à la fois, ils n'arriveraient pas à vous traîner jusqu'en paradis. ( $\mathrm{J}$ 661)

The keys are also identified by Chantal as "de vieilles habitudes" (J 662). These are the lies which she, in her own truth, refuses to carry (J 659).

Later in the text, there is no doubt that the grandmother represents the heaviness of the sins of the world. As Chantal lifts her grandmother in her arms, she exclaims:

. . je voudrais que vous soyez lourde, beaucoup plus lourde, aussi lourde que tous les péchés du monde ( $J$ 616).

silence is present within Chantal and in the deranged muteness of her grandmother. Chantal's silence is an 
interior supernatural silence. It is not "celui qui prélude aux grands débats de l'âme" like that of Donissan. But rather, a silence of a different kind which gives her the feeling of "une attente déçue" ( J 611). This interior silence contrasts to the physical silence of her grandmother who is incapable of disclosing her interior, sinful deformity.

- . debout à la même place, sa petite ombre à son côté, ainsi qu'un nain difforme. . elle ouvrait et fermait la bouche sans proférer un son. ( J 611)

Unlike the proliferation of cold imagery present in Donissan's Way of the cross, only one image of cold emerges in relation to hate in the text of La Joie. This image provides a contrast between Chantal's desire to love and pardon her grandmother and the closed-heartedness of the grandmother whose greatest sin is the inability to love.

Car la haine elle-même ne referme pas, sur un faible coeur d'homme, deux bras si glacés. Le cadavre même de la haine est plus chaud. ( J 611) Although emotionally weakened from the throes of her own suffering, and acknowledging that she barely has enough courage to sustain herself, Chantal initially resists the weight of the cross. But the rambling 
confession of her grandmother, in whose face she sees her own image, graces her with the realization that to avoid the burdens of others is to avoid God. From the outset of her way, she is conscious of her singular destination. She says:

Mama, . . il nous faut rentrer là-bas, vous et moi. Il nous faut rentrer en Dieu. ( $\mathrm{J}$ 616)

Chantal then reassures her grandmother:

N'ayez pas peur . . je suis maintenant assez forte pour vous porter. . (J 616)

Giving her grandmother a kiss on the forehead, Chantal tenderly carries her "serrée sur sa poitrine, la proie lamentable" (J 616). Chantal's load is paradoxically lightened through her expression of love. Mama, murmura-t-elle tout essoufflée, reprenant haleine, j'ai l'air de te porter: c'est toi qui me portes... ( J 616)

Jesus' expression of love was marked by suffering. Chantal's Way is likewise difficult. Fatigue and the burning sun accompany her. But a renewed joy gives her the courage to continue, and her steps become the expression of a peaceful challenge ( $J$ 616).

In the later text, Chantal carries her grandmother a second time. Once again, her burden is characterized by the same lightness. Chantal's virtuous strength makes her 
burden seem easier. She tells M. La Pérouse: "Je vais la porter jusqu'à la chambre de Fernande. . Oh! elle ne pèse pas bien lourd. . ." ( $J$ 657). It is in this context that the reader learns about Chantal's fall during her first attempt to carry her grandmother.

$$
\begin{aligned}
& \text { C'est moi qui vous ai blessée, souvenez-vous? } \\
& \text { Je ne l'ai pas fait exprès, je n'ai pu vous } \\
& \text { retenir, nous sommes tombées toutes les deux. (J } \\
& 657 \text { ) }
\end{aligned}
$$

Chantal's truthfulness calls her grandmother from her false illusions to a state of lucidity, to a momentary transformation. The grandmother recollects clearly:

$$
\begin{aligned}
& \text { Retiens-toi bien, ma jolie. Je pense à notre } \\
& \text { promenade, l'autre, souviens-t'en, tu m'as } \\
& \text { portée dans tes bras . . . ( J 658) }
\end{aligned}
$$

The text suddenly portrays the joyful Chantal as the voice of sadness. This sadness, the expression of love betrayed, mirrors the bernanosian understanding of "la Sainte Agonie."

- tristesse comparable à nulle autre. . Tristesse désintéressée, surnaturelle, pareille au reproche des anges. ( $J$ 658)

The final movement of the text underscores the graced purpose of Chantal's way of the cross. The truth of her sadness penetrates the last vestiges of her grandmother's 
dementia, a masquerade of lies. Like the Redeemer whom she models, Chantal spiritually carries her grandmother step by step towards complete conversion. Illumined as an instrument of grace, she brings to light her grandmother's sinful weakness (symbolized by the keys discussed earlier), and finally delivers her from its heaviness.

\section{The curé's way of the cross}

The curé's way is present throughout the novel on a double plane. Externally, it is "la grande route," or "la lisière" or simply "le chemin" upon which he travels to his parishioners as a ministering pilgrim. Simultaneously, it is the way of his suffering, both physically and spiritually. The external dimension as well as the personal dimension of his life-long pilgrimage are present in a scene in this novel which most closeiy resembles Jesus' Way of the cross. The curé's cross encompasses the weaknesses of his parishioners which he assumes, as well as his own spiritual and physical suffering. Unlike the dramatic and suspenseful portrayal of Donissan's Way of the cross or the mystical movement of Chantal's Way, the curé's pilgrimage reflects Jesus' suffering in a more ordinary, human way. Le chemin emprunté par le pasteur d'Ambricourt nous paraît d'emblée moins extraordinaire, plus 
familier. Sans doute parce qu'il s'agit d'un prêtre immergé dans une paroisse rurale déchristianisée, d'un curé de campagne pauvre, gauche, maladroit, et malade, en proie au doute. (Estève, Georges Bernanos: un triple 162-63)

The backdrop elements resemble those in sous le soleil de Satan, but are presented with much greater simplicity. These will be discussed first. Secondly, emphasis will be given to the way itself and the manner in which it reflects Jesus' journey to Calvary.

Similar to Donissan's way of the cross, the curé's pilgrimage also begins at night. In this novel, nighttime is an exterior darkness which parallels his difficult journey and eventually takes on a characteristic similar to Donissan's interior night. The curé writes:

La nuit m'a paru soudain plus noire, plus compacte. (JCC 1199)

As in Sous le soleil, night is also accompanied by the heaviness of silence, which like the "eau profonde" in Bernanos' first novel, closes in on the curé.

- . j'ai pensé que je tombais de nouveau, mais cette fois c'était dans le silence. J'y ai glissé d'un seul coup. Il s'est refermé sur moi. (JCC 1199) 
Another image of night is also present in Le Journal which recaptures the abandon of the mystic virgin, Chantal. Thus, this image is imbued with a positive rather than a negative connotation. Like a light in the darkness, the curé experiences the presence of "la ViergeEnfant." Although her face is a vision of sadness which is full of abandon and innocence, a virginal sadness devoid of bitterness, the virgin child represents a night of hope. "Elle faisait penser à je ne sais quelle grande nuit douce, infinie." (JCC 1198)

At the outset of the curé's trek, the terrain is a muddy clay which sticks to his shoes. In this novel too, an image of heaviness is present which signals the difficulty of his travels where "les chemins y sont mauvais" (JCC 1196). The "argile glacée" into which he falls, does not connote the dramatic presence of evil which cold images elicit in sous le soleil. The frozen clay is simply one of several exterior discomforts encountered along the way which point to the heaviness of his burden. Similar to Chantal's cross, his burden is the weight of others' sinfulness.

- . ce prêtre touche notre sensibilité et semble proche de nous, par les épreuves qu'il doit surmonter, les combats qu'il doit livrer contre l'incompréhension d'autrui, les 
faiblesses qu'il lui faut assumer. (Estève, Georges Bernanos: un triple 163)

Other discomforts of this journey come from the negative connotation of the rain-soaked grass and from the water dripping from tree branches which drenches his neck and arms (JCC 1198).

The Way itself begins in a positive spirit. At the outset, the curé's stomach pain has subsided somewhat and, encouraged, he embarks upon his mission. But very quickly his journey mirrors the suffering of Jesus' Way of the cross. Without warning, he falls a first time. This description as well as mention of the thorny brambles where he searches for his rosary suggest Another's agony. The curé's increased physical pain makes him delirious. As Jesus was consoled by his mother along the Way, the cure is consoled by the previously mentioned vision of the Virgin-Child. As he gets to his feet and continues his determined journey, he strays from the path. Sadness and agony unite in the description of his illness. He spits out blood which tastes like tears (JCC 1198). A slave of his suffering, he doesn't reject it, but accepts it like a dog follows its master (JCC 1198). Then, like Jesus, he falls a second time.

Tout à coup mon bras qui s'appuyait à la haie s'est trouvé dans le vide, tandis que le sol me 
manquait. J'étais parvenu, sans m'en douter, au bord du talus, et j'ai heurté violemment des deux genoux et du front la surface pierreuse de la route. (JCC 1198 )

In his delirium, he imagines that he gets up again, and in the profound blackness of his unconsciousness, he dreams he falls a third time.

Similar to Veronica who wiped the sweat and blood from Jesus' face as he made his way to Golgotha, a "petite Samaritaine" ministers to the curê. Seraphita Dumouchel, the curé's recalcitrant little parishioner who contrasts with the innocent child of his vision, is his Veronica. Tout en parlant, elle me passait son chiffon sur le front, les joues. L'eau fraîche me faisait du bien, je me suis levé, mais je tremblais toujours aussi fort. (JCC 1200)

As the curé prepares to continue on, Séraphita also becomes his simon of Cyrene. She says:

si vous voulez, je vous accompagnerai jusqu'au bout du chemin. . Elle est partie devant moi, puis, le sentier s'élargissant, elle s'est rangée à mon côté, et quelques pas plus loin a mis sa main dans la mienne, sagement. (JCC 1200) This part of his journey ends with the curé's greater realization of the seriousness of his illness and a 
fearful allusion to the reality of his own death. The scene concludes with the image of blood introduced by a description of the curé's cassock. "L'étoffe était raide, l'eau est devenue rouge" (JCC 1201). After washing this blood-soaked garment, the curé states: "J'ai compris que j'ai rendu beaucoup de sang" (JCC 1200). These final words sustain the portrayal of the curé as the suffering Christ. Like Jesus, powerless and humiliated in physical weakness, he is on the way to fulfill his mission as a Sacrificial Lamb.

This chapter's primary focus has been on the literal and figurative meaning of the way of the cross in each of the three novels. As imitators of Jesus' climb to Golgotha, each character experiences the weight of sinfulness in a unique way.

Donissan travels a circuitous route marked by darkness, heaviness and silence. The exterior blackness reflects his internal struggle. A direct encounter with evil is the dramatic climax of his journey filled with falls, confusion and humiliation.

Chantal's burden is the heaviness of the sinfulness which surrounds her. This mystic saint literally carries her cross symbolized by the person of her grandmother. Like Donissan, Chantal falls due to her own fatigue and suffering, but her inner spiritual strength counteracts 
the external obstacles of heat and heaviness. As a redemptive instrument of grace, she frees her grandmother from the web of lies which bind her. Her way becomes the path of her grandmother's conversion process.

The curé's way of the cross is an ordinary journey marked by his physical suffering, exterior discomforts and the interior darkness of his sadness. Literal resemblance to Jesus' Way of the cross is present in a nighttime scene full of falls, blood and a child who assumes the roles of Veronica and Simon of Cyrene. The literal similarities of the curé's Way to that of Jesus mark him as a figure on the road to death. 
CHAPTER VI

\section{DEATH AND RESURRECTION}

"And when Jesus had cried out in a loud voice, he said, 'Father, into your hands I commit my spirit'. With these words he breathed his last" (Luke 23:46). Jesus' final act of submission, his acceptance of "death on a cross" was the moment of truth fulfilled (Phil.2:8). In abject poverty, in profound humility, and stripped of life, the obedient son of the Father, accomplished his mission of redemption (Phil. 2:6). As liberator and freedom itself, embraced by His Church for all generations as the model of perfection, Jesus is the Way of authenticity and wholeness for those who imitate him. In chapter two, Bernanos' loyal adherence to this belief was presented.

Incarnate life's ultimate surrender, Jesus' death, is the ever-present hope of the bernanosian agony. Throughout his personal journey of suffering revealed through his literary creations, Bernanos embraced death in the light of faith. The reality of the final mortal moment was a continual beacon leading him forward on his journey to the fullness of light, to the profound truth of who he was before God.

Il nous dit que la vie ne peut se justifier par elle-même, qu'elle n'a de sens que comme préparation à la mort. Lucidité redoutable, 
exténuante, mais qu'il faut vouloir et aimer-car, seule, elle nous garantit que la vie fut bonne, qui fut ce chemin de la mort. Elus ou réprouvés, tous les personnages profonds de l'oeuvre vivent leur vie comme une marche vers ce dernier instant de connaissance et de jugement. Dans l'angoisse ou dans le courage, dans l'espérance de la foi ou l'énigmatique délectation du néant, ils ne veulent rien d'autre que la mort. (Picon, oeuvres xxvii)

As mentioned previously in this study, Bernanos' solemn Communion introduced him to the reality of death in a new way. From that time forward, death was his silent companion. This habitual presence constantly reflected the truth of the Christ-centered victory, a hoped-for promise even in the darkest moments. In the preface to oeuvres romanesques Picon describes Bernanos' revelation as a child. His realization was that life could not be lived in truth unless one accepts death. And death can be accepted only because Christ died for all, assuming humanity. Picon explains that Bernanos' resolution to confront death, to know how to die, to see himself die was, without a doubt, the promise made by the child to the adult, and transmitted by the adult to the dying person. (Picon xxxiii). This truth of death was a key for 
Bernanos which unlocked the obscureness of temporal vision. His ability to see beyond gifted him with the ability to present an image of eternal truth in his saintly characters. This image likewise reflects himself viewed in the reality of his own mortality, and not surprisingly, points to a Christocentric reality at the heart of his contemplation of death.

In step with the medieval pilgrim, Bernanos' quest as a writer reveals a spiritual adventure which is simultaneously a march with death towards death. It is a pilgrimage marked by self-sacrifice and a keen sense of one's mortality. It is a continual reminder of a dimension beyond oneself which elicits a unique, individual response each step of the way. For Bernanos, La mort est "la grande aventure" qui arrache toute vie à son anonymat, lui donne le caractère d'une réalité unique, impossible à répéter, c'est elle aussi qui ennoblit la vie temporelle tout entière et la mue en aventure éternelle. (Von Balthasar 430)

Death then is the final threshold which unites the contemplative pilgrim with the image in the Mirror and with the Way. However, the hope of the individual does not end with union, but continues, transformed, through participation in everlasting glory. 
The first part of this chapter highlights the bernanosian reality of death which comprises a spiritual death to self as well as mortal death. This discussion necessarily includes reference to the action of grace reflected in the life and death of each of the three Christocentric figures, Donissan, Chantal and the curé, who as bernanosian "instruments of salvation," mirror a redemptive Jesus. In the final part of this study, the resurrection is treated as the culminating transformation of the Christocentric figures into the image of Jesus. Bernanosian themes which allude to the presence of eternal life, and to the resurrection in particular, are those of dawn and the communion of saints. Their richness is explored in relationship to imitation and the eschatological pilgrimage towards fulfillment.

\section{DEATH}

A spiritual death to self presupposes a humble attitude. The presence of this childlike virtue in each of the three Christ-like figures has already been discussed in chapter three. In their ongoing individual struggle against evil, whether it be subtle temptations of pride, sadness or despair, each figure must, like Christ, accept the struggle as part of his/her agony. In each novel, an interior death to self opens Donissan, Chantal 
and the curé to their respective roles as instruments of salvation. This inner spiritual dying does not happen once and for all. It continually conforms them to the image of Christ on their personal pilgrimage right up to the moment of their mortal death. Grace sears their souls, purifying them in the process of becoming instruments of purification for others.

\section{Donissan}

Donissan's clairvoyant grace is announced by Satan in the midst of the face-to-face encounter with the enemy: "Aujourd'hui, dit-il, une grâce t'a été faite. Tu l'as payée cher. Tu la paieras plus cher!" (SS 178) In a continual struggle with despair buried in the sinuous trappings of his own pride, Donissan vows to defeat Satan even if it costs him his own salvation. As an early creation of Bernanos' clerical character, Donissan is presented

d'une violence outrée qui s'accorde mal avec l'humilité qu'il cherche. Mais la souffrance rédemptrice et la clairvoyance après la rencontre nocturne avec le tentateur est déjà là, ainsi que la volonté de se donner pour le salut des âmes. (Aaraas 141) 
In Bernanos' novels, the image of light "represents the grace of God necessary for spiritual life" (Morris 272). As an instrument of grace, Donissan is often associated with these images.

$$
\begin{aligned}
& \text { From the "petite flamme claire dans le vent" of } \\
& \text { Donissan's joy to the "lumière douce" of his } \\
& \text { interior vision and the "soleil de Dieu" evident } \\
& \text { during the resurrection, the presence of God } \\
& \text { manifests itself to Donissan, even though he } \\
& \text { often fails to recognize it. (Morris 271) }
\end{aligned}
$$

Descriptions of his apparent failure as an instrument of grace for Mouchette as well as for the "'grands enfants pleins de vices et d'ennui' qui jetaient leur écume dans son confessionnal et retournaient à leurs tristes plaisirs" (SS 254-55) enhance the powerless and humble stance of this priest (Moch 64). These episodes reinforce the darkness which comes from the rejection of grace and act as forerunners to a resurrection scene wherein the Saint of Lumbres is determined to defeat Satan. Like Jesus who called the daughter of Jairus back to life (Matt. 9:18-26) ${ }^{1}$ who gave the widow of Naim's dead son back to her (Luke 7:11-17), and called Lazarus from the tomb (John 11:1-44), the old warrior, Donissan, faces death directly. He is called to the bedside of a dead child. With vehemence, he assumes the challenge. 
Pour écraser une fois "le tenace bourreau qui s'amuse des hommes comme d'une proie" il brave "l'enfer et sa flamme". Il prend le petit garçon dans ses bras et l'élève comme une hostie.

". . il n'implore pas ce miracle il l'exige. Dieu lui doit, Dieu lui donnera, ou tout n'est qu'un songe. De lui ou de Vous, dites quel est le maître!" (SS 303-304)

The anticipated resurrection in this scene which ends in deception and humiliation casts the saintly figure in a shroud of doubt. Has Donissan been outwitted by Satan, conquered by his own prideful affront towards God and the Enemy? In a footnote, Bernanos assures the reader of his saint's salvation. The narrator refers to the child's mother who became insane following the quasi resurrection of her child, and to her subsequent healing during a pilgrimage to the Church of the saintly hero (Moch 77-78). On sait que Mme Havret fut guérie quelques mois au cours d'un pèlerinage à l'église de Lumbres. (SS 271)

It is only at the discovery of Donissan's mortal death, that this bernanosian Christ-figure is completely exonerated and that his true role as an instrument of grace is finally verified. 
Mais il est--et s'il ne le savait pas assez, Bernanos le saurait pour lui--un de ces hommes que la grâce divine a distingué du lamentable troupeau humain, l'homme 'vers qui monte la justice, à travers le temps, comme un astre'. (Moch 65)

In keeping with his humble life and the obscurity of any worldly or spiritual success, Donissan dies alone, in a confessional. Even to the end, his physical presence is symbolically situated on the battlefield of struggle with Satan. Uncompromisingly, he dies standing up.

- - il est là, bien tranquille, telle une sentinelle, tuée d'une balle dans sa guérite, à bout portant!. .

Dressé contre la paroi, les reins soutenus par l'étroit siège sur lequel il s'est renversé au dernier moment, arc-bouté de ses jambes roides contre la mince planchette de bois qui barre le seuil, le misérable corps du saint de Lumbres garde, dans une immobilité grotesque, l'attitude d'un homme que la surprise met debout. (SS 306) 


\section{Chantal}

Throughout La Joie, Chantal's saintliness is undeniable. Grace is in her and all around her. The images of light which surround her and emanate from her, "strengthening those of pure air and water, set Chantal apart as the supreme example of a soul touched by the presence of God" (Morris 277). Her own sense of littleness is augmented by her realization of this Divine presence in her life.

Si loin qu'elle remontât vers le passé, un sens exquis de sa propre faiblesse l'avait merveilleusement réconfortée et consolée, car il semblait qu'il fût en elle comme le signe ineffable de la présence de Dieu, Dieu lui-même qui resplendissait dans son coeur. ( $J$ 553)

This light attracts yet burns others with its brutal revelatory force. Chantal's assassin, Fiodor, recognizes grace and its power in face of an impenetrable, sinful obstinacy. In his description of grace, water and fire are united. The former is a cleansing element symbolizing Divine life poured out in baptism. The latter symbolizes Divine love with its purifying properties.

Hélas! madame Fernande, le secret de cette maison n'est pas le mal--non--mais la grâce. Nos âmes maudites la boivent comme l'eau, ne lui 
trouvent aucun goût, aucune saveur, bien qu'elle soit le feu qui nous consumera tous éternellement. . Q Que dire? Chacun de nous s'agite en vain, se débat; nous sommes pris entre les mailles d'un filet qui nous emporte pêle-même où nous ne voulons pas aller. ( $J$ 625) The resistance to this light and life becomes a source of interior conflict for Chantal. She is torn between the joy of its brightness where she can bask in warm waves of consolation and its harsh heat pressing her to the earth where she is called, like Jesus, to assume the sins and suffering of those around her. As a humble instrument of this grace, she lies face down on the ground and cries as she has never cried before ( $J$ 605). Her tears, symbols of expiation and humility, water the earth, a symbol of terrestrial attachment and the human condition of sinfulness (Morris 52ff). It is in this expiatory posture that she becomes a self-sacrificing instrument of grace. Following this scene, Chantal carries her grandmother to conversion. 2

The continuing self-sacrificing role of Chantal and her mortal death are closely intertwined with the conversion of Cénabre. Each step of his redemption is marked by images of light contrasted to darkness and 
heaviness. These images "leave no doubt as to the state of his soul at the end" (Morris 281).

The force of grace again appears, as the light of the room "Jaillit" (721) when Fernande first opens the door, and then, as Cénabre enters the room, "la lumière vint frapper ce visage pétrifié par une anxiété plus qu'humaine'(722). Cenabre is unable to resist the power of the light of grace. As he stands in the room under the "lumière dure" (723), trying to recite the Pater Noster, he falls forward to the floor, losing his sanity, a distinct indication that his cold reason and intellectualism have been destroyed by the light of grace. (Morris 282) Prior to his final conversion, heaviness characterizes Cénabre's efforts to climb the steps. These efforts symbolically represent the weight of his sinfulness. Aussitôt il se mit à monter à ses côtés, lentement, pesamment, comme s'il eût repoussé du front, à grand peine, un poids immense. ( $J$ 722) Darkness, contrasting to the movement of grace in his soul, surrounds Cénabre. He enters the room out of the darkness of the shadows ( $\mathrm{J} 720$ ). His momentary lucid glimpse of the gruesome murder scene reveals Chantal's miserably sprawled out body which is described by Fernande 
as a Holy Sacrament ( J 723). The connotation of sacrifice is present in this reference to Eucharist, the offering of Jesus' Body and Blood for the remission of sin. The body of the little victim ( J 723) is also described with an allusion to heaviness which connects Chantal, even in death, with the self-sacrificing image of Christ carrying his cross. This cross is first and foremost the weight of others' sinfulness.

Alors la cuisinière haussa les épaules, saisit brutalement Chantal entre ses bras. Lorsqu'il entendit rebondir sur le lit le lamentable fardeau, cénabre eut une espèce de gémissement sinistre et fit un pas en avant. --Il le fallait bien, excusez-moi, dit la grosse femme toute honteuse. Même si légère, j'ai eu du mal, j'ai les bras cassés. On voudrait plutôt la porter à genoux . . ( J 723)

The curé

The simplicity of the curé d'Ambricourt is a fire which burns his parishioners. As a prisoner of "la sainte Agonie," he is tempted to "se laisser aller, de se complaire au dédoublement et à la haine de soi, de s'abandonner au néant" (Aaraas 144). But instead, he abandons himself to love, a love, first of all, for the 
gift of self. In his own submission to Love, he becomes a grace for others and continually opens himself to grace as well. Like Donissan, he too is gifted with a clairvoyance, an ability to read souls. The countess says: ". . D'ailleurs, vous le savez, vous savez les choses avant qu'on ne vous les dise" (JCC 1163). Later, Laville tells him: "Vous avez un regard qui donne envie de raconter des histoires, n'importe quoi" (JCC 1238). Bernanos does not portray the extraordinary gifts of this cleric in a dramatic, flamboyant way, but within the natural context of ordinary human existence. The simple curé himself is surprised by his effect on people. In recounting his meeting with the countess he writes:

Les paroles que je venais de prononcer me frappaient de stupeur. Elles étaient si loin de ma pensée, un quart d'heure plus tôt! Et je sentais bien aussi qu'elles étaient irréparables, que je devrais aller jusqu'au bout. (JCC 1146)

As an instrument of grace, he is not set apart as a saintly figure who does not need conversion in his own life. Instead, he is portrayed as another fragile human being who also reaps the fruits of the conversion process. Following his interaction with the countess, he describes God's quiet action in his own life: "La paix que j'avais 
appelée sur elle était descendue sur moi. Et si simple, si familière qu'aucune présence n'aurait pu réussir à la troubler" (JCC 1164).

As in the conversion scenes of Sous le soleil and La Joie, light images which announce the presence of grace at work abound in Le Journal as well. For example, from the beginning of the curé's encounter with the countess, grace is present. A fire burns in the background. "Les bûches sifflaient dans l'âtre" (JCC 1146). A contrast between heat and cold, light and darkness identifies two forces, evil and grace, at work in the conversion process.

J'avais voulu réchauffer d'un coup ce coeur glacé, porter la lumière au dernier recès que la pitié de Dieu voulait peut-être laisser encore dans de miséricordieuses ténèbres. (JCC 1160) The curé compares the false love of self-deception to the artificial illusion of light. "Mais nous ressemblons à des fous qui tendent les bras vers le reflet de la lune dans l'eau" (JCC 1163). Just prior to the countess' sincere repentance and complete openness, descriptions of her physical appearance include references to light: "son front était luisant de sueur" (JCC 1163), and "j'ai vu monter dans son regard je ne sais quelle lueur. • ." (JCC 1164). At the moment of her renunciation of past sins, "Elle a lancé le médaillon au milieu des bûches en 
flammes" (JCC 1164). And the curé reaches into the fire in a futile effort to retrieve the lock of hair from the countess' dead child. It is consumed in the ambers. This final image of fire is God's action, grace, which purifies the last inordinate attachment of this woman on the eve of her own death.

The curé's mortal death is preceded by a childlike lucidity which expresses, not so much the warring struggle of a Donissan or the sacrificial role of Chantal, but a descent into himself where he discovers simple truth. This truth is above all a reconciliation with self. As though looking in a mirror at his reflection, he sees his own littleness.

Car je n'ai de réussite qu'aux petites choses, et si souvent éprouvé par l'inquiétude, je dois reconnaître que je triomphe dans les petites joies. (JCC 1255)

It is in this humble stance of recognizing the child he was that he embraces the end of his struggle.

N'importe! c'est fini. L'espèce de méfiance que j'avais de moi, de ma personne, vient de se dissiper, je crois, pour toujours. Cette lutte a pris fin. Je ne la comprends plus. Je suis réconcilié avec moi-même, avec cette pauvre dépouille. (JCC 1258) 
The final letter from M. Louis Dufréty to the curé de Torcy reveals the humble circumstances of the curé's death. Deprived of any legitimate ecclesial representation or sacramental consolation, his last moments pass in the small apartment of his defrocked friend.

D'épaisses gouttes de sueur coulaient de son front, de ses joues, et son regard, à peine visible entre ses paupières entrouvertes, semblait exprimer une grande angoisse. (JCC 1259)

This prisoner of the "Sainte Agonie" who confided to his journal that human agony is first and foremost an act of love (JCC 1256), remains the humble instrument of grace to the end. Like a child in distress who clings to his mother's hand, the dying curé holds his rosary "serré sur sa poitrine" (JCC 1259). With a last effort, he humbly requests absolution from Dufréty. Visibly consoled, the curé subsequently utters the words which reflect not only the union of the Divine with his very ordinary life, but the hope-filled promise of an on-going Presence. "Qu'estce que cela fait? Tout est grâce" (JCC 1259). 


\section{RESURRECTION}

The ultimate meaning and value of death, whether spiritual or mortal, does not lie with death itself in the novels of Bernanos, but in the revelation that occurs at death. The unity of death with a vision of childhood indicates not so much a return, but a rebirth to a new way of being made possible through the action of God, through grace. This new life is a transformation into oneness with God. Similar to the merging of the medieval Mirror and the way into the person of Jesus, the total transformation by grace into the perfection of christ is the bernanosian resurrection. Steps toward this eschatological way of being have already been highlighted in this study. Actions of grace in the conversion process of Bernanos' saints through whom Christ shines, and the lives they influence, proclaim the Gospel promise of Resurrection (Von Balthasar 155). This faith premise, embraced by Bernanos, is present through the mortal deaths of Donissan, Chantal and the curé. Like the song of the phoenix rising from its ashes, a resurrection refrain is present as well in two themes linked to the spiritual and physical dying of his protagonists, that of dawn and the communion of saints. Signs of resurrection in the deaths of Donissan, Chantal and the curé and these two themes, 
dawn and the communion of saints, comprise the final consideration of this study.

\section{Signs of resurrection}

The stiff, upright body of Donissan, determined even in death to wage war against Satan, is found by the illustrious author, Saint-Marin. The title of his book, Cierge Pascal, refers to the liturgical Pascal Candle blessed and used throughout the Easter season by the church. Although the book itself is presented as an unrealistic treatise about sainthood, its titular link to the Resurrection brings a subtle, ironic hint of victory to the death scene of Donissan. The theme of resurrection as a continuation of life after death, is also present through the written word in sous le soleil. Death does not silence the saint of Lumbres. He continues to defend the defenseless against the enemy. "Non! son dernier mot n'est pas dit. . Le vieil athlète percé de mille coups témoigne pour de plus faibles, nomme le traître et la trahison. . ." (SS 307). His final complaint to the Judge is neither one of despair nor of condemnation. It is a "loving reproach" (SS 308). Thus, despite the disconcerting description of Donissan's death and the defiant tone of his last defense, the novel ends in the hope of victory. 
Long before Chantal's death, Bernanos alludes to a Iife of transparence, the realm of God which is beyond present reality. Chantal exclaims: "Combien les saints se font transparents!" ( J 603) She continues: "Il faudrait n'être qu'un cristal, une eau pure. Il faudrait qu'on vît Dieu à travers" ( $\mathrm{J}$ 603). In death, the transparency of her virtue is painted spontaneously by Fernande: "Elle n'était jamais assez humiliée, elle ne désirait que le mépris, elle aurait vécu dans la poussière. . Elle aura tout renoncé, monsieur, je vous dis, même sa mort" ( 723). Words connoting eternity and life introduce resurrection language into Bernanos' description of the dead body of his martyred saint. In this same passage, an ironic twist of words parallels the stony Cénabre with the corpse of Chantal.

Le prêtre restait debout, sous la lumière dure. Aucune sagesse humaine, ni même le génie de la compassion, n'eût rien trouvé à lire sur les traits immobiles qu'une volonté prodigieuse, à l'agonie, sculptait du dedans, marquait du signe de l'éternel. Une minute, une longue minute, la balance oscilla entre la morte toujours vivante, et ce vivant déjà mort. ( J 723)

The novel concludes with the action of transforming grace. Cénabre begins to pray with a superhuman voice ( $J$ 
724). His "Pater Noster" barely begun, holds the promise of his redemption through the continued instrumentality of the deceased Chantal. With Cénabre's death indicated in a final footnote, the hope of resurrection lingers like a glorious chord resounding beyond the last lines of the novel.

The curé also lives on after his death. The letter to the curé de Torcy from Dufréty commits the curé d'Ambricourt's last moments to continued memory. In a commentary on this last testament, Aaraas suggests that it is not only an account of the redemptive death of the curé, but a witness to the resurrection. He contends that Dufréty's initial description is bogged down in a stilted precious style geared to impress the curé de Torcy. But suddenly, an authentic voice replaces that of Dufréty. C'est la voix du Journal, la voix du curé d'Ambricourt, et on la reconnaît sans peine. • Il s'agit d'une véritable résurrection, certes pas dans la chair, mais dans le langage, de cette voix qui s'est tue pour un moment, mais qui rejaillit de nouveau pour imposer la certitude que cet homme vit! Tout se passe comme si ce prêtre, à qui il est révélé que sa place était choisie pour lui de toute éternité. - ce prêtre qui vit de la Vie du Christ, qui 
partage son agonie et sa mort, participe aussi à sa résurrection. (Aaraas 156-57)

Even without the letter, the little priest's diary remains as a testament to his simple life. Both of these documents represent him well. His diary, in particular, reflects a life continually in the process of transformation. His final realization, "tout est grâce," is perhaps his first knowing glimpse of resurrected life wherein "La Sainte Agonie" shared by this saint is recognized as an eternal embrace of "La douce Pitié de Dieu" (JCC 1230). ${ }^{3}$

$\underline{\text { Dawn }}$

In the three synoptic accounts of the resurrection, it is dawn when the empty tomb is discovered. In the Gospel of Matthew, it is "towards dawn on the first day of the week" (Matt.28:1), while in Mark the text reads, "And very early in the morning on the first day of the week they went to the tomb, just as the sun was rising" (Mark $16: 2)$. In Luke, the women carry spices to the tomb "on the first day of the week, at the first sign of dawn . . . (Luke 24:1). Although the Resurrection theme was not emphasized directly in the medieval period, the promise of eternal life was present through emphasis on the creation and incarnation. God, looking after his handiwork with 
maternal tenderness, sent a Son who was the perfect instrument of salvation. Eternal life resulted from conformity to Him, through grace, to the image of God.

The hope of being filled with God through the light of grace is physically symbolized in the majestic medieval cathedrals. Shaped in the form of a cross, the head of this redemptive symbol, the central place of worship for the community of the faithful, faces eastward. Pointed towards the rising sun, the tomb-like darkness of such a structure was literally filled with the light of dawn. This light transformed the cathedral's interior into color and splendor. Such radiance passing through the structure's magnificent windows dissipated shadows and renewed hope for eternal glory. Similar to the medieval cathedrals which symbolically unite the darkness of the Passion and Cross with the light of transformation, Bernanos' saintly children, engulfed in "la sainte Agonie," are renewed and refreshed in the mystical reality of dawn. Béguin succinctly captures the bernanosian role of dawn as a sign of hope. It is almost always present in Bernanos' reference to a childhood revisited at the moment of death.

Comment ne pas remarquer, dans tous les textes de Bernanos touchant à la Mort et à la Peur, ces images d'aube et de matin--'ô mort si frâ̂che! ô 
seul matin. . une aube fraîche et profonde'-qui y reparaissent toujours, comme d'ailleurs elles ne font guère défaut aux pages où il s'agit de l'enfance. Ce sont les images de l'espérance, les mêmes qui environnent d'une naissante lumière les départs rimbaldiens sur les routes, ces départs dont nous disions qu'ils n'avaient point d'autre but que le Royaume de Dieu • . (51)

The image of dawn is equated with consolation following the experience of anguish. In a letter to one of his friends on December 23, 1940, Bernanos reflects on his own experience in which a hope-filled dawn is mentioned. L'espèce de tristesse où je vis maintenant m'est devenue chère, parce que c'est celle de mon pays, et plus je m'y enfonce, plus je me rapproche de lui. Je suis entré dans la nuit française, mais je sais bien qu'en allant courageusement jusqu'au bout de la nuit, on rencontre une autre aurore. (qtd. in Béguin $51)^{4}$

Dawn is unquestionably equated with eternal life and "la douce pitié de Dieu."

- . dans un article paru au Brésil en janvier 1945, dira-t-il que le sort commun des hommes 
est de mourir avec le sentiment de leur tâche inaccomplie et de connaître, à l'heure de l'agonie, ce suprême déchirement, avant de se réveiller, le seuil franchi, dans la douce pitié de Dieu, comme dans une aube fraîche et profonde. Et l'après-mort s'appelle pour lui "un éternel matin". (qtd. in Béguin 51) 5

In Sous le soleil, a reference to dawn is present in Donissan's written complaint found after his death. This image appears as a time of final reckoning, but also as a beginning time.

L'univers, que le péché nous a ôté, nous le reprendrons pouce par pouce, nous vous le rendrons tel que nous le reçûmes, dans son ordre et sa sainteté, au premier matin des jours. (SS 307 )

In this short reference, the saint of Lumbres promises the slow, determined conquest of sin, and the return of untainted spoils from his war against satan to the creator. His long night of battle is about to end. In Donissan's note, the "premier matin des jours" can be interpreted as both the beginning of time and the end of time. This phrase marks a familiar landmark on a circular journey. As a starting point, it is identified as the initial order and sacredness of the universe. As an 
ending, it is the same order and sacredness restored and transformed into a new beginning. In short, this image of morning conveys the reality of the Eternal which has been ever-present throughout Donissan's journey.

The eternal quality of the dawn image is figuratively present in La Joie. Early in the novel, the "day" in all its splendor of light is associated with "joy." "La joie du jour, le jour en fleur, un matin d'août, avec son humeur et son éclat, tout luisant. . ." (J 552). The unearthly, pure, quality of this light is quickly counterbalanced with negative terrestrial descriptions. As though impeding the weightlessness of the morning light from drifting into an expanse of eternal bliss, Bernanos ties it to less pure and heavier images: "l'air trop lourd," "les perfides aromates d'automne," "la brume insidieuse," "la terre épuisée," les prés défrấchis," "l'eau dormante avec l'odeur des feuillages taris" ( 552). The perfection of this morning, tranquil and transparent, is immediately shadowed. Its earthly setting fetters its pristine nature. Elements of fragility and destruction announce the incarnational symbolism present in the image. "C'était la joie du jour, et par on ne sait quelle splendeur périssable, c'était aussi la joie d'un seul jour, le jour unique, si délicat, si fragile dans son implacable sérénité. . " ( J 552). 
Chantal is the joy of the morning. Her presence in this novel is light incarnate. "De son pas juste et léger, rarement hâtif, la jeune fille traversa toute cette lumière. . " ( J 552). Later, Bernanos describes her as being filled with divine light in prayer which "jaillit de toutes parts, recouvrit tout" ( J 681). As a redemptive figure, she unveils momentarily the resurrectional promise in her prayerful transparency. "Elle pût désormais les envelopper et les étreindre de ce regard intérieur qui baignait dans un autre jour" ( J 681).

Dawn is a time of refreshment and renewed hope for the suffering curé as it was for Bernanos himself. After a difficult night of pain, the curé is awakened to a new day by light and water. He writes: "Mauvaise nuit. A l'aube la pluie m'a réveillé. Elle passait à travers le vitrail brisé" (JCC 1103). Liturgically, the elements of light and water are major symbols of the Pascal celebration. The blessing of water and the new fire on the eve of the Feast of the Resurrection represent the sacramental life of the church through which grace is channeled. These elements are also healing properties and bring physical and spiritual strength. With healing and reconciliation come hope and new beginnings. The image of dawn is this healing grace for the curé. "La délivrance de l'aube m'est toujours aussi douce. C'est comme une grâce 
de Dieu, un sourire. Que les matins soient bénis!" (JCC 1208)

Another resurrection theme emerges in the motorcycle episode of Le Journal where the image of dawn is once again imbued with hope and consolation. In this scene, images of light, "machine flamboyante" and "un éclair" surround the morning with victorious radiance. The description of the motorcycle recalls an old Testament prototype of the resurrection. The fiery chariot of the prophet Ezekiel carries him to the heavens. ". . . a chariot of fire appeared and horses of fire, coming between the two of them; and Elijah went up to heaven in the whirlwind" (2 Kgs.2:11-12). Like Enoch of the Book of Genesis, Elijah did not die, but was simply "taken by God" (Gen. 5:24). In the old Testament story, the miraculous prophetic actions of Elijah are continued or "resurrected" through a youth, his progeny, Elisha. The motorcycle journey, ethereal next to the darkness of the curé's outward attire and inner spirit of sadness, similarly liberates a cocooned youthfulness to the glories of life, to the beginning of a "triumphant" day.

A côté de cette machine flamboyante, ma soutane faisait une tache noire et triste. Par quel miracle me suis-je senti à ce moment-là jeune, si jeune--ah! oui, si jeune--aussi jeune que ce 
triomphal matin? En un éclair, j'ai vu ma triste adolescence-- . . Cela était devant moi comme une personne, un être (vivant ou mort, Dieu le sait!) (JCC 1211) 6

This scene, a preview of resurrected liberation, opens the way for an escalation of dawn imagery. From this point on, the curé's decline towards death is punctuated by expressions of faith and hope in grace, symbolized consistently by dawn imagery.

Je me suis levé, j'ai bu un verre d'eau, et j'ai prié jusqu'à l'aube. C'était comme un grand murmure de l'âme. Cela me faisait penser à l'immense rumeur des feuillages qui précède le lever du jour. Quel jour va se lever en moi? Dieu me fait-il grâce? (JCC 1223)

Dawn imagery appears again after his illness is diagnosed. The curé resists the reality of his condition and his consolation of the hope-filled morning dissipates. Through blind faith, he is aware that the light of grace is still present within him. His perceived darkness comes from the knowledge of his impending physical death and an accompanying spiritual numbness.

M'échapper! Fuir! Retrouver ce ciel d'hiver, si pur, où j'avais vu ce matin, par la portière du wagon, monter l'aube! M. Laville a dû s'y 
tromper. La lumière s'est faite d'ailleurs en moi tout à coup. Avant qu'il eût achevé sa phrase, je n'étais déjà plus qu'un mort parmi les vivants. (JCC 1239-40)

The same, almost prophetic imminence of death is expressed in the final reference to dawn in the curé's journal. This reference carries a double-planed image of both a natural morning and a supernatural one. The curé's posture is one of readiness. Alert to the sounds of a waking morning, he awaits a final eternal dawn.

Je me suis endormi un instant, les coudes sur la table. L'aube ne doit pas être loin, je crois entendre les voitures des laitiers. (JCC 1256)

\section{Communion of Saints}

The death of the bernanosian saints is an act of love. Moving in the pilgrimage of communion with both heaven and earth, Bernanos' protagonists mirror the incarnational dying of Jesus all along the way. They become the perfected pilgrim through their death which, like Jesus' death, is a final act of redemptive supplication for the salvation of the human family. This movement is based on an ecclesial concept which Bernanos embraced. It is the Church's theological emphasis on the mutual salvific role of the faithful, both on earth and in 
heaven. Union of the members of Christ's Body for the purpose of glorifying the Father in and through the oneness of the spirit are the central components of this faith premise.

The pilgrim is always in danger of feeling constricted and oppressed by his anxiety for his salvation. When the spirit gives him the perfected angels and saints as brothers in every way close to him, he reveals himself as the love who gives the one Christ, the life of all, ever more fully as the fellowship grows wider. 7

Embracing this concept, Bernanos presents the destiny of the human race as a common one.

Nul plus que lui n'est persuadé qu'il existe une "communion des saints", une communauté totale de destins et de responsabilitiés qui concerne ce qu'il y a de plus profond dans les personnes. . - bien universel de tous les chrétiens . . en tant que chacun d'eux est destiné à la contemplation de Dieu. A ce niveau, il n'y a plus de distinction possible entre la nature et le surnaturel: l'homme devient véritablement libre, en tant que personne, dans le risque de la grâce. (Von Balthasar 71) 
The end of the bernanosian journey, therefore, is not singularly marked for a few saints who leave other pilgrims behind blinded and choking in the dust of their delusions. Like Jesus, Bernanos' saints move among and with the motley crowd of sinners. Donissan, Chantal and the curé do not detach themselves from their respective environments to soar with grace-filled superiority to purer celestial regions. Nor do they abandon themselves to the dark, earthly encumbrances of their fellow pilgrims. Rather, uniting earth and heaven in their person, they plead as the incarnate Jesus pleaded. In Sous le Soleil, Donissan's last lament before God is one of supplication for those he served, for those whose salvation is as precious as his own. It echoes his continual struggle against the ensnaring tricks of Satan divulged in the dark confines of the confessional. - - il n'entend que ce murmure à peine distinct, la voix de ses fils à genoux, pleine de honte. Ah! qu'ils parlent ou se taisent, la grande âme impatiente a déjà devancé l'aveu, ordonne, menace, supplie!. . Regardez ces enfants, Seigneur, dans leur faiblesse! leur vanité, aussi légère et aussi prompte qu'une abeille, leur curiosité sans constance, leur raison courte, élémentaire, leur sensualité 
pleine de tristesse. . , entendez leur langage, à la fois fruste et perfide, qui n'embrasse que les contours des choses, riche de la seule équivoque, assez ferme quand il nie, toujours lâche pour affirmer, langage d'esclave ou d'affranchi, fait pour l'insolence et la caresse, souple, insidieux, déloyal. (SS 276) 8

Chantal, likewise, pleads for those around her in the sacrificial, humble offering of her person.

Elle ne songeait qu'à le servir, les servir tous, et d'abord les plus déshérités, dont sa tendresse infaillible avait éprouvé le néant, qu'elle sentait vides. "Pauvres pécheurs! comme ils sont vides!" disait le vieux Chevance. Quels pécheurs? Sa charité ne les nommait pas, elle ne séparait aucune unité de ce pâle troupeau de fantômes. A quoi bon? Pourvu qu'elle restât seulement docile à Dieu, qu'elle se fît chaque jour plus claire pour ouvrir et réjouir tant de misérables regards encore clos, plus fervente pour les réchauffer sous leurs suaires, éveiller leurs coeurs dormants. "Si Dieu se laissait voir, pensait-elle tristement, ils l'aimeraient plus que moi, peut-être?. . ."




Perhaps the least dramatic yet direct testimony of Bernanos' concept of "communion of saints" is expressed by the curé. This simple, emaciated priest reflects on his experience in a tavern where he takes refuge after learning the fatal nature of his illness. His fragile appearance is ridiculed by some customers. Undisturbed, the humble cure's thoughts turn inward where he finds a comforting silence. It is in this interior space, in the core of his own being, where the hospitable and loving interdependence of souls is elegantly described.

Le silence intérieur--celui que Dieu bénit--ne m'a jamais isolé des êtres. Il me semble qu'ils y entrent, je les reçois ainsi qu'au seuil de ma demeure. Et ils $y$ viennent sans doute, ils $y$ viennent à leur insu. Hélas! je ne puis leur offrir qu'un refuge précaire! Mais j'imagine le silence de certaines âmes comme d'immenses lieux d'asile. Les pauvres pécheurs, à bout de forces, y entrent à tâtons, s'y endorment, et repartent consolés sans garder aucun souvenir du grand temple invisible où ils ont déposé un moment leur fardeau. (JCC 1230)

The selfless concern for others by all three characters expresses the love which is at the heart of the mystery of "communion of saints." Love's final testament 
in the stories of Donissan, Chantal and the curé comes with death. "La mort est de la part de l'homme un acte d'amour. C'est le retour à Dieu" (Moch 90). In Dialogues des Carmélites, Bernanos writes: "On ne meurt pas chacun pour soi, mais les uns pour les autres, ou même les uns à la place des autres" (qtd. in Moch 90). This total act of self-giving exacts freedom. In his Lettre aux anglais, Bernanos proclaims: ". . I'homme libre, seul, peut aimer" (qtd. in Von Balthasar 73).9 This liberty is synonomous with truth because it flows from the knowledge and love for self realized through total surrender.

La seule vraie connaissance de soi est celle qui se fait en Dieu; or, en Dieu l'homme ne se voit pas lui-même, mais par la foi, c'est Dieu luimême qu'il voit. Ce regard est sa vérité. (Von Balthasar 196)

Truth, then, is the realm of transparency where the bernanosian pilgrim will no longer "see in a mirror dimly, but. . face to face." In this domain of ultimate union with the Divine, these transformed imitators of Jesus will understand fully even as they have been fully understood (1 Cor. 13:12). Through love which "never ends" (1 Cor. 13:8) their experience of resurrected liberation, the fruit of their faith and hope, will be their eternal reality. 
The preceding presentation of each protagonist's spiritual death to self as well as descriptions of the mortal death of Donissan, Chantal and le curé emphasized, in particular, their roles as instruments of grace. The presence of light imagery was explored as it surrounded each of these redemptive figures.

Moving across the threshold of death to total transformation, the bernanosian Christ figures live on as exemplars of the Way. In this chapter, the concept of eternal life was explored through textual discovery of dawn and light imagery in relation to each character as well as to rich symbolic association with light-filled medieval Cathedrals, liturgical celebration and old Testament prototypes. Lastly, Bernanos' strong adherence to a belief in the communion of saints was demonstrated through textual examples. This belief symbolizes the universality of a common journey towards the truth of oneself which ultimately frees the pilgrim to love. 
NOTES

1 Mark 5:21-43; Luke 8:40-56.

2 see chapter five of this study.

3 see also: Bernanos, "Article paru au Brésil," janvier 1945, qtd. in Béguin, Bernanos 51 .

---. "Sur 1'album d'une jeune fille brésilienne," qtd. in Bêguin, Bernanos 96. Béguin, Bernanos 55 .

Par tant de combats livrés et de souffrances assumées, il avait mérité d'apparaître, quelques minutes après sa mort, comme quelqu'un qui s'est vu accueillir sans délai dans 'la douce pitié de Dieu'. 4 ---. "Letter to a Brazilien friend." 5 ---. "Letter to a Brazilien friend."

6 some contemporary commentaries have interpreted the curé's experience here as a moment of adolescent passion or liberation of repressed sexuality related to his celibate state. Such an interpretation is compatible within a resurrectional context. In this study, resurrection is the culmination of an individual's journey towards wholeness. This wholeness includes body and spirit. Whatever the interpretation, the curé's experience was a human one and to view it only as physical or only as spiritual would neglect a basic bernanosian (and theological) premise, namely, that grace works in and 
through nature, not above or beyond it. Moeller cautions against failure to consider the whole individual, particularly in relation to psychoanalytic diagnostic tendencies of contemporary society. ". . à traiter par des moyens purement psychiques, sans tenir compte de l'élément spirituel qu'il comporte, échoueraient." (Moeller 378)

7 "Communion of Saints," Encyclopedia of Theology The Concise Sacramentum Mundi, ed. Karl Rahner, (New York: Crossroad, 1982) 276 .

8 This passage ends with "Pater, dimitte illis, non enim sciunt quid facient!" (SS 276) ("Father, forgive them for they know not what they do.")

9 Bernanos, Lettre aux Anglais (Paris: Gallimard, 1948) 242 . 
CONCLUSION

This study has identified similarities to medieval spirituality within three of Georges Bernanos' fictional works, Sous le soleil de Satan, La Joie, and Journal d'un curé de campagne. The treatment of two central medieval images, the Mirror and the Way, provided a contextual background and unifying thread to the christocentric focus on the bernanosian protagonists, Donissan, Chantal and le curé.

In the first chapter of Part one, after establishing a base from which a spirituality could be considered, the discussion presented some key formative elements to a medieval spirituality. These included: the medieval mindset which, among other characteristics, did not distinguish between the real and supernatural; influences of clerics as preachers and exemplars for living the faith; the Church's role in fostering devotional trends, particularly through the Eucharist and the Hours; the flourishing of the imitation of Christ movement through renewed devotion to the humanity of Jesus in the latter half of the Middle Ages; emphasis on edification with a detailed description of two prime medieval images, the Mirror and the Way; and the ideals of chivalry as they were christianized through integration into the church. 
In the second chapter, formative elements in the spirituality of Bernanos were described. Emphasis was given to those influences which particularly parallelled the medieval themes presented in chapter one. Similarities to the medieval mindset as well as themes of pilgrimage, chivalry and imitation were the main considerations of this chapter. Bernanos' Christocentric spirituality was emphasized along with the virtues he most emulated in his person and in his literary creation.

In Part Two, which turned to a textual discovery of the medieval characteristics in the bernanosian novels, the first consideration was childhood as it related to elements in the medieval devotion to the Infancy of Jesus. Christ-like virtues of poverty, humility, simplicity, and tenderness as well as the innocence and purity of heart which characterize the chivalrous child were highlighted through textual analysis. The quest of each protagonist was defined as a vocational salvific role.

In the next two chapters, characteristics of the medieval devotion to the Passion which emerged in the suffering of Bernanos' Christ figures were presented. This presentation likewise involved textual analysis. Concentration in chapter four was on Jesus' agony as experienced in unique ways by Donissan, Chantal and the curé. Donissan's suffering is primarily an interior 
struggle with temptation. Chantal's agony, which emulates most literally the sufferings of Jesus in the Garden of Olives, is surrounded by malevolent forces. The cure's agony comprises real physical suffering as well as the darkness of spiritual sadness.

The bernanosian saints' imitation of the way of the cross in the context of the medieval image of the way and related imagery were examined in chapter five. Donissan's circuitous road and his chilling encounter with the treacherous tempter were described. Chantal's efforts to carry the heaviness of sinfulness both literally and figuratively were explored. And the cure's ordinary and dedicated treks on country roads to minister to his parishioners in spite of his personal suffering were examined.

In the last chapter, the relationship between the final steps of the medieval journey of imitation and the journey of Bernanos' saints was considered. These steps are death and resurrection. Descriptions of each character's spiritual death to self and each one's mortal death were presented. These descriptions reflect the redemptive role of Donissan, Chantal and the curé as instruments of grace reminiscent of the medieval exemplar. The resurrection was treated as the culminating transformation of the bernanosian saints into the image of 
Jesus. Themes of dawn and the communion of saints were included as important medieval and bernanosian indicators of resurrected life.

Although centuries link the medieval era to Bernanos' presence in contemporary times, the message that a spiritual world exists is consistent in both. The Christocentric focus of the Middle Ages and in Bernanos' novels is made visible through the images of the way and the Mirror. Their deepest meaning speaks of the reality of the human search towards wholeness. It is a search filled with longing, adventure and struggle. Through Bernanos' voice, which echoes strongly in his literary creations, he reminds the world of a single Reality capable of confronting a contemporary Church and society with the truth and hope of the human journey. It is the same Reality embraced by the medieval period, the human and divine Model, Jesus. 
APPENDIX A

ABBREVIATIONS USED FOR BERNANOS'S WORKS

IN THIS THESIS

JCC Journal d'un curé de campagne

J La Joie

SS Sous le soleil de satan 


\section{WORKS CONSULTED}

BIBLIOGRAPHY OF BERNANOS AND BERNANOSIAN STUDIES

\section{Primary Sources}

Bernanos, Georges. Les grands cimetières sous la lune.

Paris: Plon, 1986.

--- Correspondance. Recueillie par Albert Béguin.

Choisie et présentée par Jean Murray, O.P. 2 vols.

Tome I: 1904-1934. Tome II: 1934-1948. Paris: Plon, 1971.

--. Le Lendemain c'est vous!. Paris: Plon, 1969.

--- Les Cahiers du Rhône. Recueillis par Albert Béguin. Paris: Editions du Seuil, 1949.

---. oeuvres romanesques suivies de Dialogues des Carmélites. Préface par Gaëton Picon. Texte et variantes établis par Albert Béguin. Notes par Michel Estève. Bibliothèque de la Pléiade. Paris: Gallimard, 1961.

\section{Secondary Sources}

Aaraas, Hans. Littérature et sacerdoce: essai sur

"Journal d'un curé de campagne" de Bernanos. Paris: Minard, 1984. 
Beaumont, Ernest. "Le Sens christique de l'oeuvre romanesque de Bernanos." Etudes Bernanosiennes 3-4, Revue des lettres modernes 81-84 (1963): 85-106. Béguin, Albert. Bernanos par lui-même. Paris: Seuil, 1961 .

Brée, Germaine, and Margaret Guiton. An Age of Fiction: The French Novel from Gide to Camus. New Brunswick, New Jersey: Rutgers UP, 1957.

Bridel, Yves. L'Esprit d'enfance dans l'oeuvre romanesque de Georges Bernanos. Paris: Minard, 1966. Brodin, Pierre and Dorothy. Présences Contemporaines. New York: French \& European Publications, Inc., 1972. Bush, William. "La Souffrance des innocents." Etudes Bernanosiennes 1, Revue des lettres modernes 56-57 $(1960): \quad 107-23$.

--- Souffrance et expiation dans la pensée de Bernanos. Paris: Minard, 1962 .

Chaigne, Louis. Georges Bernanos. Paris: Editions Universitaires, 1954.

Cooke, John E. Georges Bernanos, a Study of Christian Commitment. Amersham: Avebury, 1981. Estève, Michel. Bernanos. Paris: Gallimard, 1965. --- "Genèse du Journal d'un curé de campagne." Etudes Bernanosiennes 2, Revue des lettres modernes 67-68 $(1961-62): 499-512$. 
---. "Quelques aspects de la transcription du surnaturel dans l'oeuvre romanesque de Bernanos." Le Français dans le monde 11 Sept. 1963: 39-46.

--. Georges Bernanos: un triple itinéraire. Paris: Hachette, 1981.

Fabrègues, Jean de. Bernanos tel qu'il était. Paris: Mame, 1963.

Fitch, Brian T. Georges Bernanos: Journal d'un curé de campagne. London: Arnold, 1970.

---. "Georges Bernanos et André Malraux: confrontation de deux univers romanesques." Etudes bernanosiennes 6 , Revue des lettres modernes 127-29 (1965): 5-24.

---. "Aspects de la structure de la phrase chez Bernanos et Céline." Etudes bernanosiennes 6 , Revue des lettres modernes 127-29 (1965): 85-101.

Fragnière, Marie Agnes. Bernanos fidèle à l'enfant. Fribourg: Editions Universitaires, 1963. Gaucher, Guy. "Bernanos et Sainte Thérèse de l'Enfant Jésus." Etudes Bernanosiennes 1, Revue des lettres modernes 56-57 (1960): 227-68.

---. Le Thème de la mort dans les romans de Georges Bernanos. Paris: Minard, 1967.

Lagarde, André et Laurent Michard. xxe Siècle. Paris: Les Editions Bordas, 1962. 
Marie-Céleste, Soeur. "Bernanos et Graham Greene."

Etudes Bernanosiennes 6 , Revue des lettres modernes $127-29(1965): 45-70$.

Mesnier, Pierre Marie. Univers imaginaire et poétique du surnaturel dans Nouvelle histoire de Mouchette de

Bernanos. Paris: Lettres modernes, 1974.

Moch, Léa. La sainteté dans les romans de Georges

Bernanos. Paris: Les Belles Lettres, 1962.

Moeller, Charles. Littérature du Xxe siècle et

christianisme. 5 vols. Paris: Casterman, 1954.

Morris, Daniel R. From Heaven to Hell: Imagery of Earth,

Air, water and Fire in the Novels of Georges

Bernanos. New York: Peter Lang Publishing, Inc., 1989.

Pézeril, Daniel. "Adieu à Bernanos." Dieu Vivant 12 $(1948): 11-16$.

Reck, Rima Drell. "Bernanos et Dostoïevski: le dépassement du roman policier dans Un Crime et crime et châtiment." Etudes bernanosiennes 6, Revue des lettres modernes 127-29 (1965): 71-84.

Simon, Pierre-Henri. Témoins de l'homme. Paris: Librairie Armand Colin, 1963.

Urs Von Balthasar, Hans. Le chrétien Bernanos. Trans. Maurice de Gandillac. Paris: Seuil, 1956. 
Vernières, Bernard. Bernanos: l'aventure humaine dans "Sous le soleil de Satan. Fleury-sur-orne: Librairie Minard, 1992 .

\section{BIBLIOGRAPHY OF MEDIEVAL SPIRITUALITY THEOLOGY AND IMAGERY}

Armstrong, Regis J., O.F.M. Cap. and Brady, Ignatius, O.F.M., Francis and Clare, The Complete Works. New York: Paulist Press, 1982.

Bachelard, Gaston. L'Air et les songes: essai sur l'imagination du mouvement. 2nd ed. Paris: Corti, 1959 .

---. L'Eau et les rêves: essai sur l'imagination de la matière. Paris: Corti, 1942.

---. La Psychanalyse du feu. 15th ed. Paris: Gallimard, 1958 .

Beaune, Colette. The Birth of an Ideology: Myths and Symbols of a Nation in Late-medieval France. Trans. Susan Ross Huston. Ed. Fredric L. Cheyette. Berkeley: University of California Press, 1991. Bradley, Sr. Rita Mary, C.H.M. "Backgrounds of the Title 'Speculum' in Medieval Literature." Speculum 29 $(1954): 100-115$. 
Braso, Gabriel M., O.S.B. Liturgy and Spirituality. Trans. Leonard J. Doyle. Minnesota: The Liturgical Press, 1971.

Bugge, John. Virginitas, An Essay in the History of a Medieval Ideal. The Hague: Martinus Nijhoff, 1975. Bynum, Caroline walker. Holy Feast And Holy Fast. Berkeley: University of California Press, 1987. ---. Jesus as Mother. Berkeley: University of California Press, 1982.

Chenu, N.D. Nature, Man and Society in the Twelfth Century. Ed. and trans. Jerome Taylor and Lester $\mathrm{k}$. Little. Chicago: University of Chicago Press, 1979. Common Bible, Revised Standard Version (Ecumenical Edition). New York: Collins, 1973. Dante Alighieri, The Divine Comedy (2: Purgatorio and 3: Paradiso). Trans. with a commentary by John D. Sinclair. New York: Oxford University Press, 1961. Delaruelle, Etienne. La Piété Populaire au Moven Age. Torino: Bottega d'Erasmo, 1975.

De Robeck, Nesta. St. Clare of Assisi. Milwaukee: The Bruce Publishing Co., 1951.

Dictionnaire de spiritualité ascétique et mystique doctrine et histoire. Di Bernardo, Flavio, "Passion (Mystique de la)," 1983 ed., Tome 12, 312-38. Noye, Irénée, "Enfance de Jésus (Dévotion à 1')," 1960 ed., 
Tome 4, 651-82. Schmidt, "Miroir," 1980 ed., Tome $10,1290-1303$

Duby, Georges. France in the Middle Ages 987-1460. Trans. Juliet Vale. Oxford: Blackwell, 1991.

Eliade, Mircea. Images and Symbols: Studies in Religious Symbolism. Trans. Philip Mairet. New York: Sheed and Ward, 1969.

Englebert, Omer. Saint Francis of Assisi, A Biography. Michigan: Servant Books, 1979.

Erickson, Carolly. The Medieval Vision: Essays in History and Perception. New York: Oxford University Press, 1976 .

Fortini, Arnaldo. Francis of Assisi. Trans. Helen Moak. New York: The Crossroad Publishing Co., 1981. Frye, Northrop. The Great Code: The Bible and Literature. New York: Harcourt, 1982.

Gardiner, Eileen. Medieval Visions of Heaven and Hell.

New York: Garland Publishers, 1993.

Hourlier, Jacques, O.S.B. "The Medieval Masters." In Jesus and Christian Devotion and Contemplation. Ed. P. Malatesta, S.J. Hertfordshire: Anthony Clarke, 1974.

Howe, Helen and Robert T. Howe. The Medieval World. New York: Longman, 1988. 
Kieckhefer, Richard. Unquiet Souls. Chicago: University of Chicago Press, 1984.

Lapsanski, Duane. Evangelical Perfection. New York:

Tipografia Porziuncula, 1977.

Leclercq, Jean. The Love of Learning and the Desire for

God. New York: Fordham University Press, 1961.

---. Monarchisme et Pérégrination du IXe au XIIe

Siècle." Studia Monastica 3 (1961): 33-51.

--- Francis Vandenbroucke and Louis Bouyer. The

Spirituality of the Middle Ages. Vol. 2. New York:

Seabury Press, 1968.

Léon-Dufour, Xavier. Dictionary of Biblical Theology.

New York: The Seabury Press, 1977.

Malatesta, F., S.J., ed. Imitating Christ. Hertfordshire:

Anthony Clarke, 1974.

McBrian, Richard P. Catholicism. Minnesota: Winston

Press, Inc., 1981.

McCracken, George Englert. Early Medieval Theology.

Trans. and Ed. George E. MCCracken and Allen

Cabaniss. Philadelphia: Westminster Press, 1957.

McKenzie, John L., S.J. Dictionary of the Bible. New

York: Macmillan Publishing Co., Inc., 1978.

Muir, Lynette R. Literature and Society in Medieval

France. New York: St. Martin's Press, 1985. 
Navone, John, S.J. Communicating Christ. England: St. Paul Publications, 1976.

--. Towards a Theology of Story. England: St. Paul Publications, 1977.

Paxton, Frederick S. Christianizing Death. Ithaca:

Cornell University Press, 1990.

Poulain, A., S.J. The Graces of Interior Prayer. St. Louis, Mo.: B. Herder Book Co., 1949.

Rahner, Karl, S.J. Visions and Prophecies. New York:

Herder and Herder, 1963.

---, ed. Encyclopedia of Theology: The Concise

Sacramentum Mundi. New York: Crossroad, 1982.

Schnurer, Gustav. Church and Culture in the Middle Ages.

Trans. George J. Undreiner. New Jersey: St. Anthony

Guild Press, 1956.

Smalley, Beryl. Studies in Medieval Thought and Learning.

London: The Hambledon Press, 1981.

--- The Study of the Bible in the Middle Ages. New York: Oxford University Press, 1941.

Throckmorton, Jr., Burton H. ed. Gospel Parallels.

Tennessee: Thomas Nelson Publishers, 1979.

Turner, Victor. The Ritual Process. New York: Cornell University Press, 1977.

--. Dramas, Fields and Metaphors. Ithaca: Cornell University Press, 1974. 
Underhill, Evelyn. Mysticism. New York: E.P. Dutton, 1911.

Vauchez, André. The Laity In The Middle Ages. Indiana: University of Notre Dame Press, 1987.

Vorreux, Le Père Damien. Première Rencontre avec François

D'Assise. Paris: Editions Franciscaines, 1976.

Wilson, Adrian and Joyce Lancaster Wilson. A Medieval.

Mirror: Speculum humanae salvationis. Berkeley:

University of California Press, 1984.

Woods, Richard, O.P., ed. Understanding Mysticism. New York: Image Books, 1980. 